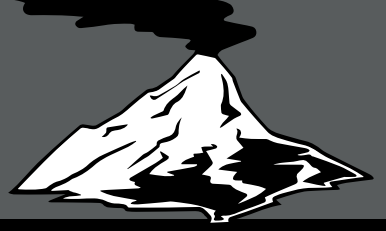

\title{
Geologic Field-Trip Guide to the Lassen Segment of the Cascades Arc, Northern California
}

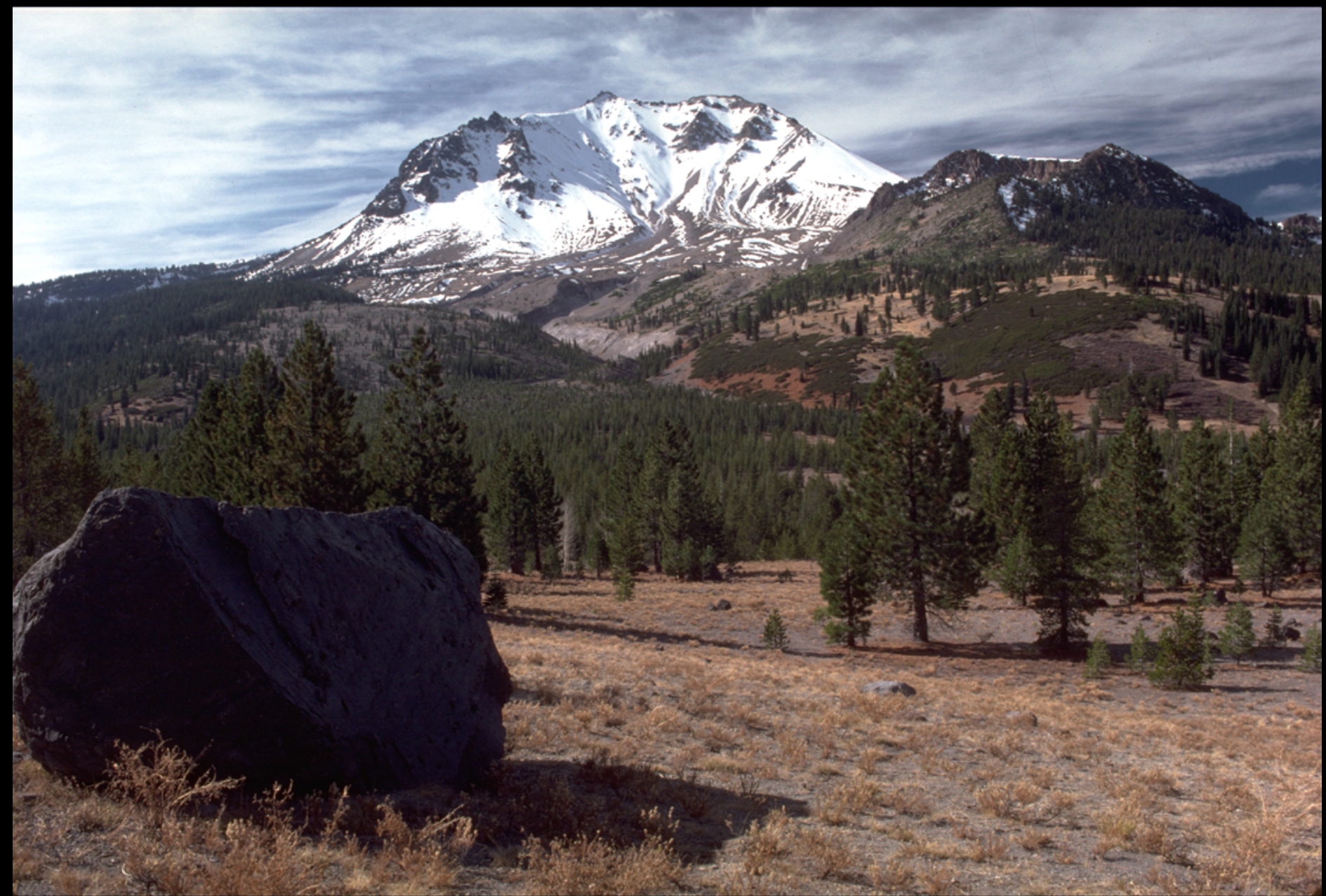

Scientific Investigations Report 2017-5022-K2 
Cover: Photograph looking southwest from Emigrant Pass towards Lassen Peak (27 \pm 1 ka) in the center and Crescent Crater (236 \pm 1 ka) on the right. Photograph taken in October 1986 by M.A. Clynne. 


\section{Geologic Field-Trip Guide to the Lassen Segment of the Cascades Arc, Northern California}

By Michael A. Clynne and L.J. Patrick Muffler

Scientific Investigations Report 2017-5022-K2 


\title{
U.S. Department of the Interior \\ RYAN K. ZINKE, Secretary
}

\section{U.S. Geological Survey William H. Werkheiser, Acting Director}

\author{
U.S. Geological Survey, Reston, Virginia: 2017
}

For more information on the USGS — the Federal source for science about the Earth, its natural and living resources, natural hazards, and the environment-visit https://www.usgs.gov or call 1-888-ASK-USGS.

For an overview of USGS information products, including maps, imagery, and publications, visit https://store.usgs.gov.

Any use of trade, firm, or product names is for descriptive purposes only and does not imply endorsement by the U.S. Government.

Although this information product largely is in the public domain, it may also contain copyrighted materials as noted in the text. Permission to reproduce copyrighted items must be secured from the copyright owner.

Suggested citation:

Clynne, M.A., and Muffler, L.J.P., 2017, Geologic field-trip guide to the Lassen segment of the Cascades Arc, northern California: U.S. Geological Survey Scientific Investigations Report 2017-5022-K2, 65 p., https://doi.org/10.3133/ sir20175022K2.

ISSN 2328-0328 (online) 


\section{Preface}

The North American Cordillera is home to a greater diversity of volcanic provinces than any comparably sized region in the world. The interplay between changing plate-margin interactions, tectonic complexity, intra-crustal magma differentiation, and mantle melting have resulted in a wealth of volcanic landscapes. Field trips in this series visit many of these landscapes, including (1) active subduction-related arc volcanoes in the Cascade Range; (2) flood basalts of the Columbia Plateau; (3) bimodal volcanism of the Snake River Plain-Yellowstone volcanic system; (4) some of the world's largest known ignimbrites from southern Utah, central Colorado, and northern Nevada; (5) extension-related volcanism in the Rio Grande Rift and Basin and Range Province; and (6) the spectacular eastern Sierra Nevada featuring Long Valley Caldera and the iconic Bishop Tuff. Some of the field trips focus on volcanic eruptive and emplacement processes, calling attention to the fact that the western United States provides opportunities to examine a wide range of volcanological phenomena at many scales.

The 2017 Scientific Assembly of the International Association of Volcanology and Chemistry of the Earth's Interior (IAVCEI) in Portland, Oregon, marks the first time that the U.S. volcanological community has hosted this quadrennial meeting since 1989, when it was held in Santa Fe, New Mexico. The 1989 field-trip guides are still widely used by students and professionals alike. This new set of field guides is similarly a legacy collection that summarizes decades of advances in our understanding of magmatic and tectonic processes of volcanic western North America.

The field of volcanology has flourished since the 1989 IAVCEI meeting, and it has profited from detailed field investigations coupled with emerging new analytical methods. Mapping has been enhanced by plentiful major- and trace-element whole-rock and mineral data, technical advances in radiometric dating and collection of isotopic data, GPS (Global Positioning System) advances, and the availability of lidar (light detection and ranging) imagery. Spectacularly effective microbeam instruments, geodetic and geophysical data collection and processing, paleomagnetic determinations, and modeling capabilities have combined with mapping to provide new information and insights over the past 30 years. The collective works of the international community have made it possible to prepare wholly new guides to areas across the western United States. These comprehensive field guides are available, in large part, because of enormous contributions from many experienced geologists who have devoted entire careers to their field areas. Early career scientists are carrying forward and refining their foundational work with impressive results.

Our hope is that future generations of scientists as well as the general public will use these field guides as introductions to these fascinating areas and will be enticed toward further exploration and field-based research.

Michael Dungan, University of Oregon Judy Fierstein, U.S. Geological Survey Cynthia Gardner, U.S. Geological Survey Dennis Geist, National Science Foundation

Anita Grunder, Oregon State University John Wolff, Washington State University

Field-trip committee, IAVCEI 2017 


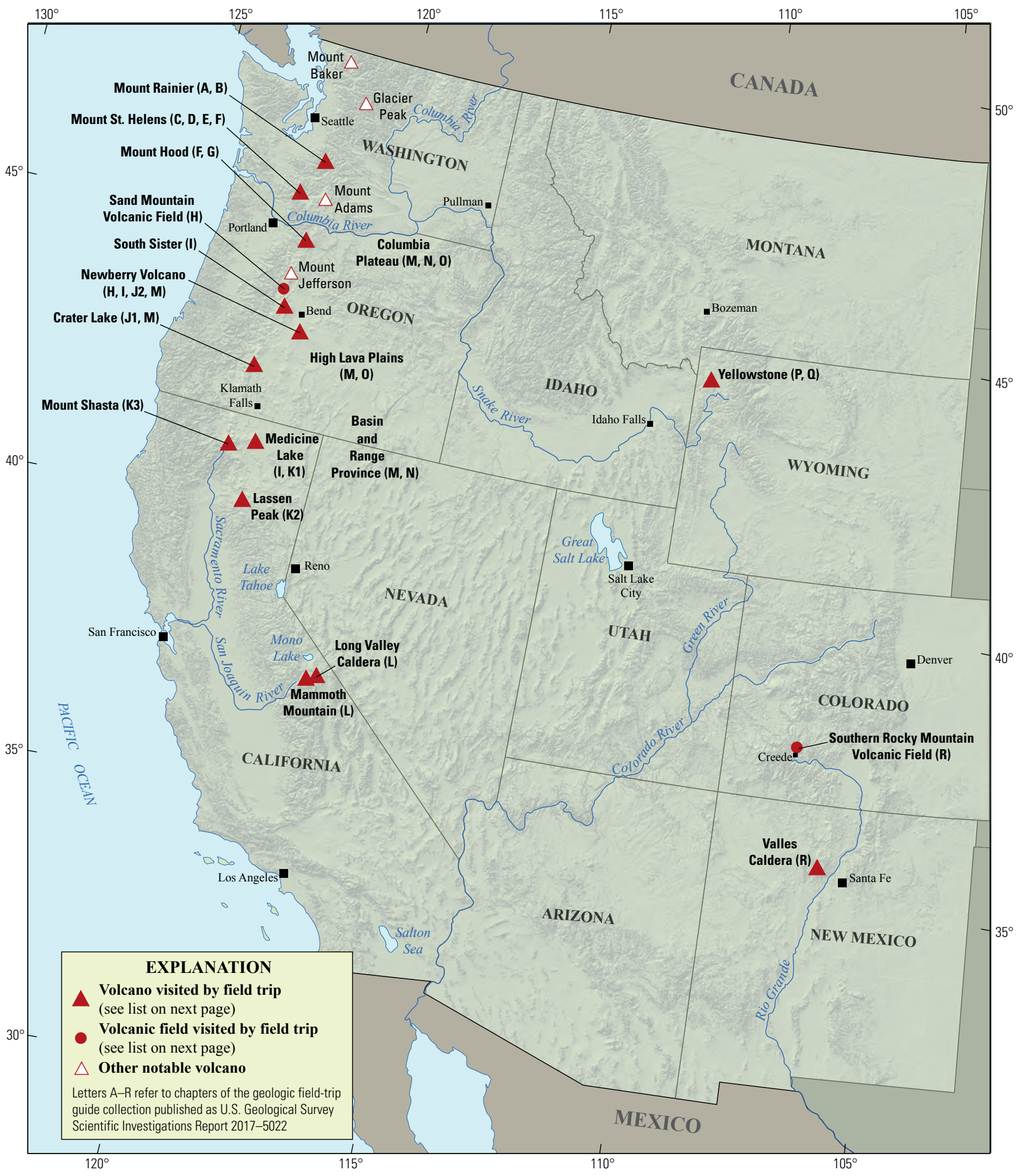

Map of the western United States showing volcanoes and volcanic fields visited by geologic field trips scheduled in conjunction with the 2017 meeting of the International Association of Volcanology and Chemistry of the Earth's Interior (IAVCEI) in Portland, Oregon, and available as chapters in U.S. Geological Survey Scientific Investigations Report 2017-5022. Shaded-relief base from U.S. Geological Survey National Elevation

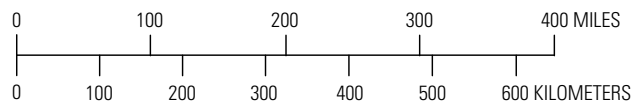
Dataset 30-meter digital elevation model data. 


\section{Chapter \\ letter Title}

A

B

C

D

E

F

G

H
Field-Trip Guide to Volcanism and Its Interaction with Snow and Ice at Mount Rainier, Washington

Field-Trip Guide to Subaqueous Volcaniclastic Facies in the Ancestral Cascades Arc in Southern Washington State-The Ohanapecosh Formation and Wildcat Creek Beds

Field-Trip Guide for Exploring Pyroclastic Density Current Deposits from the May 18, 1980, Eruption of Mount St. Helens, Washington

Field-Trip Guide to Mount St. Helens, Washington—An overview of the Eruptive History and Petrology, Tephra Deposits, 1980 Pyroclastic Density Current Deposits, and the Crater

Field-Trip Guide to Mount St. Helens, Washington—Recent and Ancient Volcaniclastic Processes and Deposits

Geologic Field-Trip Guide of Volcaniclastic Sediments from Snow- and Ice-Capped Volcanoes-Mount St. Helens, Washington, and Mount Hood, Oregon

Field-Trip Guide to Mount Hood, Oregon, Highlighting Eruptive History and Hazards

Field-Trip Guide to Mafic Volcanism of the Cascade Range in Central Oregon-A Volcanic, Tectonic, Hydrologic, and Geomorphic Journey

Field-Trip Guide to Holocene Silicic Lava Flows and Domes at Newberry Volcano, Oregon, South Sister Volcano, Oregon, and Medicine Lake Volcano, California

Overview for Geologic Field-Trip Guides to Mount Mazama, Crater Lake Caldera, and Newberry Volcano, Oregon

Geologic Field-Trip Guide to Mount Mazama and Crater Lake Caldera, Oregon

Field-Trip Guide to the Geologic Highlights of Newberry Volcano, Oregon

Overview for Geologic Field-Trip Guides to Volcanoes of the Cascades Arc in northern California

Geologic Field-Trip Guide to Medicine Lake Volcano, northern California, including Lava Beds National Monument

Geologic Field-Trip Guide to the Lassen Segment of the Cascades Arc, northern California

Geologic Field-Trip Guide to Mount Shasta Volcano, northern California

Geologic Field-Trip Guide to Long Valley Caldera, California

Field-Trip Guide to a Volcanic Transect of the Pacific Northwest

Field-Trip Guide to the Vents, Dikes, Stratigraphy, and Structure of the Columbia

River Basalt Group, Eastern Oregon and Southeastern Washington

Field-Trip Guide to Flood Basalts, Associated Rhyolites, and Diverse Post-Plume Volcanism in Eastern Oregon

Field-Trip Guide to the Volcanic and Hydrothermal Landscape of Yellowstone Plateau, Montana and Wyoming

Field-Trip Guide to the Petrology of Quaternary Volcanism on the Yellowstone Plateau, Idaho and Wyoming

Field-Trip Guide to Continental Arc to Rift Volcanism of the Southern Rocky Mountains-Southern Rocky Mountain, Taos Plateau, and Jemez Volcanic Fields of Southern Colorado and Northern New Mexico 


\section{Contributing Authors}

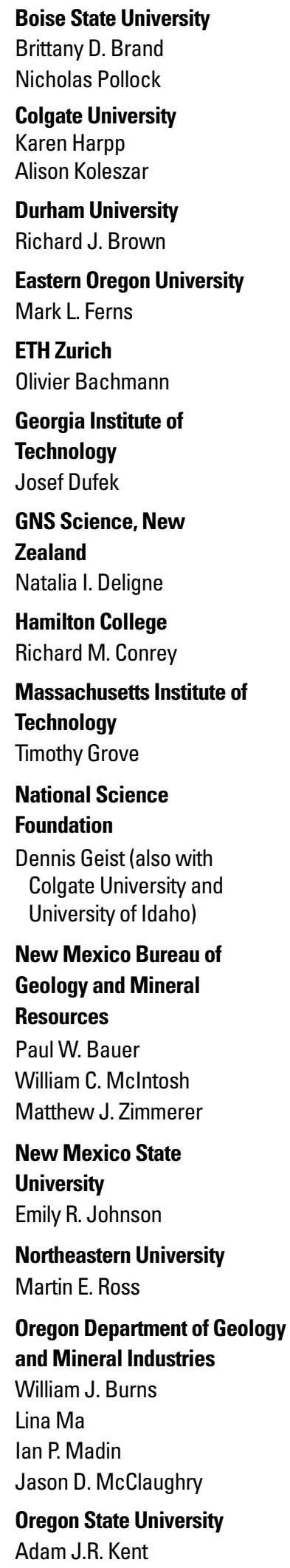

\author{
Portland State University \\ Jonathan H. Fink (also with \\ University of British Columbia) \\ Martin J. Streck \\ Ashley R. Streig
}

San Diego State University
Victor E Camp

Smithsonian Institution

Lee Siebert

Universidad Nacional

Autónoma de San Luis Potosi

Damiano Sarocchi

University of California, Davis

Kari M. Cooper

University of Liverpool

Peter B. Kokelaar

University of Northern

Colorado

Steven W. Anderson

University of Oregon

Ilya N. Binderman

Michael A. Dungan

Daniele Mckay (also with Oregon State University and Oregon State University, Cascades)

University of Portland Kristin Sweeney

University of Tasmania

Martin Jutzeler

Jocelyn McPhie

University of Utah

Jamie Farrell

U.S. Army Corps of

Engineers

Keith I. Kelson

\section{U.S. Forest Service}

Gordon E. Grant (also with Oregon State University)

\section{U.S. Geological Survey}

Charles R. Bacon

Andrew T. Calvert

Christine F. Chan

Robert L. Christiansen

Michael A. Clynne

Michael A. Cosca

Julie M. Donnelly-Nolan

Benjamin J. Drenth
William C. Evans

Judy Fierstein

Cynthia A. Gardner

V.J.S. Grauch

Christopher J. Harpel

Wes Hildreth

Richard P. Hoblitt

Robert A. Jensen

Peter W. Lipman

Jacob B. Lowenstern

Jon J. Major

Seth C. Moran

Lisa A. Morgan

Leah E. Morgan

L.J. Patrick Muffler

Jim O'Connor

John S. Pallister

Thomas C. Pierson

Joel E. Robinson

Juliet Ryan-Davis

Kevin M. Scott

William E. Scott

Wayne (Pat) Shanks

David R. Sherrod

Thomas W. Sisson

Mark Evan Stelten

Weston Thelen

Ren A. Thompson

Kenzie J. Turner

James W. Vallance

Alexa R. Van Eaton

Jorge A. Vazquez

Richard B. Waitt

Heather M. Wright

U.S. Nuclear Regulatory

Commission

Stephen Self (also with University of California, Berkeley)

Washington State University Joseph R. Boro

Owen K. Neill

Stephen P. Reidel

John A. Wolff

\section{Acknowledgments}

Juliet Ryan-Davis and Kate Sullivan created the overview map, and Vivian Nguyen created the cover design for this collection of field-trip guide books. The field trip committee is grateful for their contributions. 


\section{Contents}

Preface

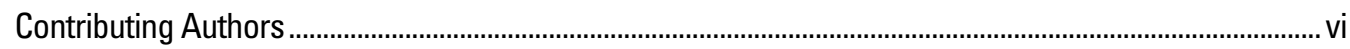

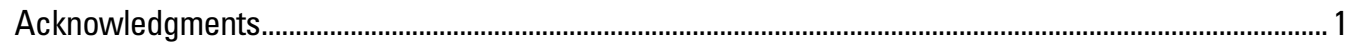

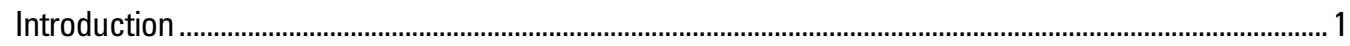

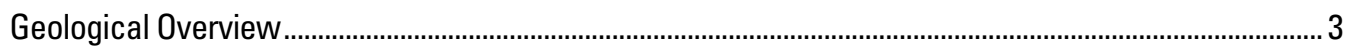

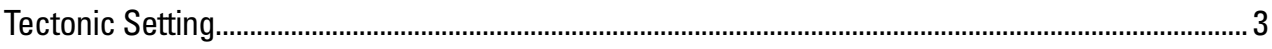

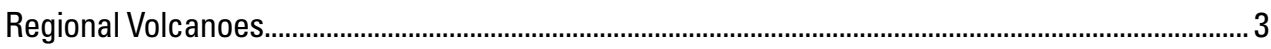

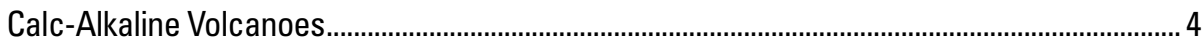

Low-Potassium Olivine Tholeite .....................................................................................

Parental Magmas and Evolution of the Regional Suite .................................................................

Volcanic Centers ........................................................................................................................... 8

Eruptive History of the Lassen Area...........................................................................................

Regional Volcanic Rocks ............................................................................................. 10

Yana and Latour Volcanic Centers and the Tuscan Formation.................................................... 11

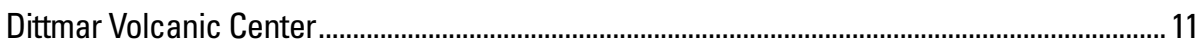

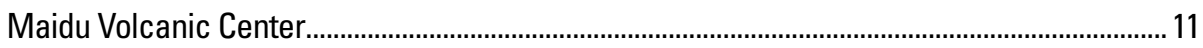

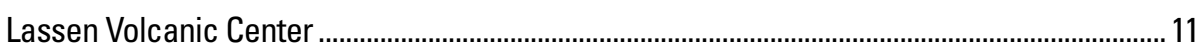

Rockland Caldera Complex.................................................................................................... 13

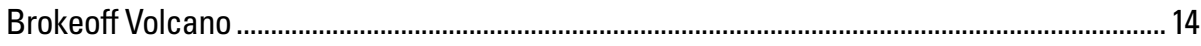

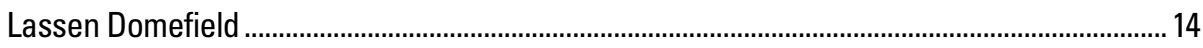

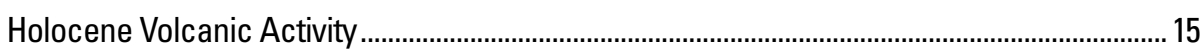

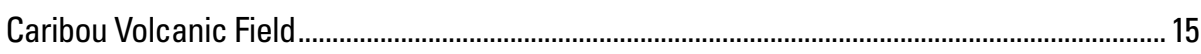

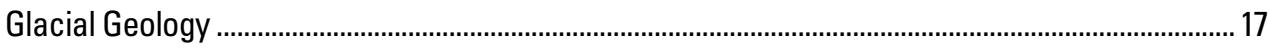

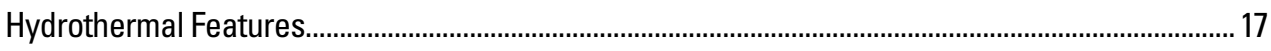

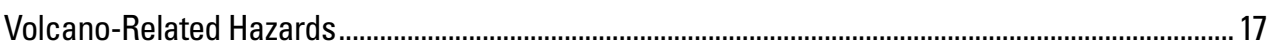

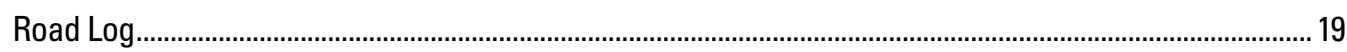

Day 1 (Pole Creek to Chester) …….........................................................................................

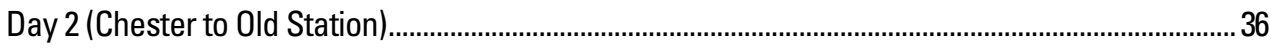

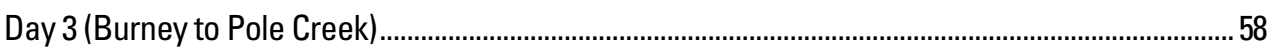

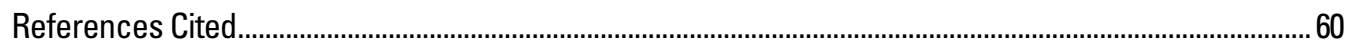

\section{Figures}

1. Index map of the Lassen region of the Cascade Range............................................................... 2

2. Map showing regional tectonic setting of area from Sacramento Valley to CaliforniaNevada border, including Lassen Volcanic National Park and vicinity, California ................4

3. Map of Lassen Volcanic National Park and vicinity emphasizing calc-alkaline and tholeiitic volcanic rocks that surround the Lassen Volcanic Center........................................................ 5

4. Graph of $\mathrm{K}_{2} \mathrm{O}$ content against $\mathrm{SiO}_{2}$ content of regional volcanic rocks in the Lassen area....... 6

5. Multielement spider diagram showing concentrations of trace elements in primitive basalts of the Lassen region ...................................................................................................7

6. Diagrammatic cross section showing magmagenesis model for the Lassen region .................. 8 
7. Map and chronostratigraphic chart of volcanic centers in the Lassen region 9

8. Generalized geologic map and chronostratigraphic chart of Lassen Volcanic National Park and vicinity, California, emphasizing the location, extent, and stratigraphy of the Lassen Volcanic Center.

9. Graph of $\mathrm{SiO}_{2}$ content versus $\mathrm{K}_{2} \mathrm{O}$ content for 250 analyses of volcanic rocks from the Lassen Volcanic Center grouped by eruptive sequence

10. Generalized geologic map of eastern part of Lassen Volcanic National Park and

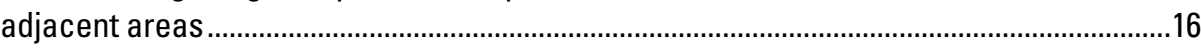

11. Diagrammatic cross sections of the Lassen hydrothermal system .......................................... 18

12. Map showing thermal areas in and adjacent to Lassen Volcanic National Park ...................... 19

13. Photograph of pillows at the base of the tholeitic basalt of Pole Creek........................................ 21

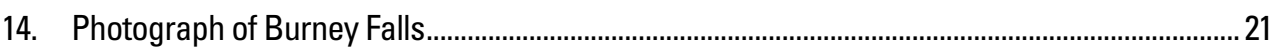

15. Geologic map showing the distribution of the six tholeiitic basalt flows in the northern

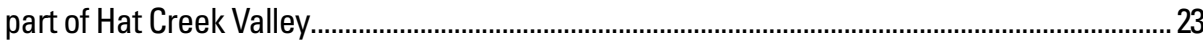

16. Panoramic photograph of the Cascades Volcanic Arc and Hat Creek Valley............................. 24

17. Generalized geologic map of the northward-flowing Hat Creek Basalt..................................... 25

18. Panoramic photograph looking south from Bidwell Road towards the Cascades Volcanic Arc..

19. Oblique satellite image with perspective view down and to the northeast of the northern part of the Hat Creek Fault.

20. Annotated photograph from Stop 3 looking south along the "Active Scarp" ............................ 27

21. Panoramic photograph looking southwest to northwest from Parhams Point across the Hat Creek Graben and the Hat Creek Basalt......................................................................... 29

22. Photograph looking west-southwest towards the Lassen domefield ........................................ 31

23. Geologic map of the Poison Lake chain ......................................................................... 32

24. Photograph looking southwest across Silver Lake, illustrating the glaciated physiography

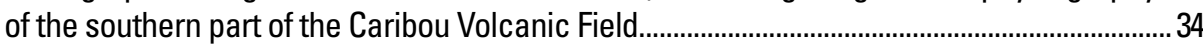

25. Telephoto view looking northwest from the fault scarp just east of the northernmost part

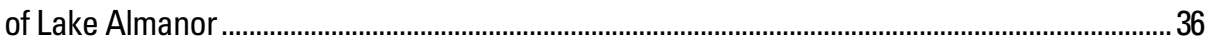

26. View looking north from cliffs on east side of Mill Creek ...........................................................3

27. Photograph looking west at andesite flow exposed in the face of Bluff Falls quarry ................39

28. Photograph showing landslides in hydrothermally altered volcanic rocks.............................. 41

29. Annotated photograph showing changes of hydrothermal features at Sulphur Works from 2004 to 2005,2008 , and 2009

30. Photograph taken in November 2011 of mudpot $P$ at Sulphur Works ...................................... 42

31. Photograph of Brokeoff Mountain looking west from turnout on Calif. Hwy 89 south-southwest of Diamond Peak..

32. Photograph looking southwest at a glacial erratic of the dacite of Bumpass Mountain resting on polished and striated andesite of Mount Diller..

33. View looking east-southeast from trail at the west end of Bumpass Hell................................. 45

34. Photograph of the northeast flank of Lassen Peak taken by B.F. Loomis in June 1913, before the 1914-1917 eruption

35. Photograph of the Devastated Area taken by B.F Loomis on the morning of May 22, 1915, before the Plinian eruption at $\sim 4$ p.m, later that day

36. Photograph showing the Devastated Area after the eruption of May 22, 1915 ......................... 47

37. Chart giving a summary of events in the 1914-1917 eruptions of Lassen Peak .......................... 48

38. Generalized geologic map of deposits from the May 1915 eruptions at the summit of Lassen Peak. 
39. Photograph of the May 22, 1915, crater at the summit of Lassen Peak ......................................50

40. Low-angle oblique aerial photograph looking southwest at Lassen Peak and the proximal Devastated Area.

41. Telephoto view northeast from summit of Brokeoff Mountain looking at Lassen Peak and the west lobe of the dacite flow of May 19-20, 1915.

42. Photographs of hand specimens of four rock types of very different appearance that were produced over a weeklong period during the May 1915 eruption from the summit of Lassen Peak

43. Chart giving a summary of events in the formation of Chaos Crags .............................................53

44. Photograph of Chaos Crags and Chaos Jumbles looking southeast from Calif. Hwy 89..........54

45. Graph of $\mathrm{SiO}_{2}$ content versus $\mathrm{K}_{2} \mathrm{O}$ content for the quenched mafic inclusions and host

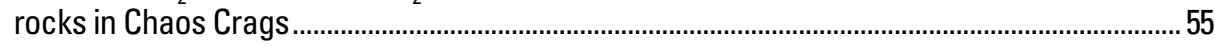

46. Photograph of quenched mafic inclusion in dacite/rhyodacite of Chaos Crags .......................56

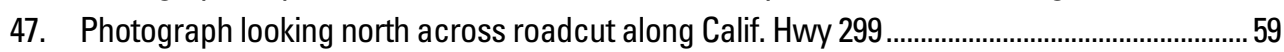





\title{
Geologic Field-Trip Guide to the Lassen Segment of the Cascades Arc, Northern California
}

\author{
By Michael A. Clynne and L.J. Patrick Muffler
}

\section{Acknowledgments}

A project of the scope and size of our Lassen investigations could not possibly be completed without the assistance and consultation of colleagues. We particularly acknowledge the significant collaborations of Robert Christiansen and Marianne Guffanti. We were ably assisted over the course of geologic mapping by a number of geologists, primarily Lars Borg, Marianne Guffanti, Gordon Keating (deceased), Deborah Trimble, Jacob Madden, Charles Melancon, and Miranda Fram. We are also grateful to Tracey Felger, Joel Robinson, David Ramsey, Dillon Dutton, Ellen Lougee, and Peggy Bruggman for providing assistance, instruction, and collaboration with GIS compilation.

Geochronologic data are essential to the satisfactory completion of any modern geologic study in volcanic terrane. The volcanic stratigraphy presented herein reflects the major contributions of Brent Dalrymple, Marvin Lanphere, Andrew Calvert, Brent Turrin, Deborah Trimble, and Paul Renne, each of whom contributed age dates on a variety of materials. Potassiumargon (K-Ar) and argon-argon $\left({ }^{40} \mathrm{Ar} /{ }^{39} \mathrm{Ar}\right)$ ages given in the text and figure captions of this guide can be found in Clynne and Muffler (2010) unless otherwise noted. Paleomagnetic data and correlations contributed by Duane Champion played a major role in refining volcanic stratigraphy, particularly in the Poison Lake chain and the Hat Creek Valley.

Reviews of the manuscript by Marianne Guffanti, and Thomas Giachetti improved both the content and presentation of this guide. We are particularly grateful for the thorough and constructive editing provided by Claire Landowski.

\section{Introduction}

This field-trip guide provides an overview of Quaternary volcanism in and around Lassen Volcanic National Park, California (fig. 1), emphasizing the stratigraphy of the Lassen Volcanic Center. Much of this guide is taken directly from the Geologic Field-Trip Guide to Lassen Volcanic National Park and Vicinity (Muffler and Clynne, 2015), although Sections A (from Red Bluff), C (from Chico), G (alternate loop to Cinder Cone), and $\mathrm{H}$ (to Redding) of that guide are not duplicated here. The present guide, as well as Muffler and Clynne (2015), draw heavily on the introductory text for the "Geologic Map of Lassen Volcanic National Park and Vicinity" (Clynne and Muffler, 2010). Both guides are designed to be self-guided and to focus on geologic features and stratigraphy that can be seen easily from the road network. Discussions of geochemistry and petrology are limited to generalities; users who desire more comprehensive information on these subjects should consult the works in the reference list provided.

A useful supplement to this field-trip guidebook is the set of 48 annotated photographs in the CD-ROM (Muffler and others, 2010) accompanying the geologic map of Clynne and Muffler (2010). To access the photos from the CD-ROM, click on "site" and then the photos folder. The annotated photos also are at http://pubs.usgs.gov/sim/2899/database.html (click on "photographs").

Lassen Volcanic National Park comprises $430 \mathrm{~km}^{2}$ of scenic volcanic features, glacially sculpted terrain, and the most spectacular array of thermal features in the Cascade Range. Interest in preserving the scenic wonders of the Lassen area arose in the early 1900s and led to the establishment in 1907 of two small national monuments centered on Lassen Peak and Cinder Cone (Strong, 1989). The eruptions of Lassen Peak in 1914-15 were the first in the Cascade Range since widespread European settling of the American West in the late 1800s. Through the print media, the eruptions aroused considerable public interest and inspired renewed efforts to establish a national park. In 1916, Lassen Volcanic National Park (LVNP) was established by combining the previously established national monuments with adjacent Federal lands.

The Lassen region is bounded on the west by the Sacramento Valley and the Klamath Mountains, on the south by the Sierra Nevada, on the east by the Basin and Range Province, and on the north by Mount Shasta and Medicine Lake volcanoes. Rocks exposed in the Lassen region are primarily volcanic rocks ranging in age from 3.5 million years old (Ma) to 100 years old. A profound unconformity separates these late Cenozoic volcanic rocks from underlying sedimentary rocks of Cretaceous age and metamorphic and igneous rocks of Paleozoic and Mesozoic age. These much older rocks crop out in the mountains south and southeast of Lake Almanor, in the canyons of Mill Creek and Deer Creek 20 miles south-southwest of LVNP, and in the area of Montgomery Creek 16 miles northwest of LVNP.

Diller (1895) recognized the young volcanic geology of the region and made the first geologic map of the Lassen area. A 1:48,000-scale map of LVNP, produced in one remarkable field season by Williams (1932), was extended by later geologic mapping, notably by Wilson (1961) and by Macdonald (1963, 1964, 1965). Investigations by the USGS over the past 38 years have led to a detailed 1:24,000 "Geologic map of the Lassen Peak, Chaos Crags, and upper Hat Creek area, California" (Christiansen and others, 2002) 




Figure 1. Index map of the Lassen region of the Cascade Range. Field-trip route is shown as heavy, colored lines (purple for day 1, green for day 2, and orange for day 3). Numbered red circles show stop locations. 
and a 1:50,000 "Geologic map of Lassen Volcanic National Park and vicinity" (Clynne and Muffler, 2010). The latter map is accompanied by a CD-ROM (Muffler and others, 2010) that contains ArcGIS-compatible data files used to create the 1:50,000-scale geologic map, geologic and topographic data and their associated metadata files, printable versions of the geologic map and pamphlet as PDF files, and 1:24,000-scale geologic maps of individual quadrangles used to compile the 1:50,000 map. It also contains ancillary data that support the map, including locations of rock samples selected for chemical analysis and radiometric dating, links to related data or websites, and 48 annotated photographs of geologic features. Data contained in the CD-ROM are also available at http:// pubs.usgs.gov/sim/2899/. Chemical analyses and locations of samples are given in Clynne and others (2008).

\section{Geological Overview}

\section{Tectonic Setting}

Figure 2 (reproduced here from Clynne and Muffler, 2010) illustrates the tectonic setting of the Lassen segment (Guffanti and Weaver, 1988) of the Cascades Volcanic Arc. Volcanism in the Lassen segment is a result of oblique subduction of the oceanic Gorda Plate eastward beneath the continental North American Plate. From 12 million years ago (12 Ma) to the present, the axis of the Lassen segment migrated westward from the California-Nevada border to its present position (Guffanti and others, 1990). Simultaneously, the width of the arc narrowed, probably because the subduction angle steepened. The southern terminus of active volcanism retreated roughly parallel to the northward extension of the San Andreas Fault System and migration of the Mendocino Triple Junction off the northern California coast. At $12 \mathrm{Ma}$, the southern limit of Cascades volcanism was in the Sierran block south of Lake Tahoe, 110 miles $(180 \mathrm{~km}$ ) southeast of the Lassen area (Busby and others, 2008; Busby, 2013). At $3 \mathrm{Ma}$, the southern limit of active volcanism was in the area of the Yana Volcanic Center, 18 miles $(30 \mathrm{~km})$ south of Lassen Peak. At present, the southern limit of active volcanism corresponds approximately to the south boundary of LVNP, where the youngest dated volcano is Sifford Mountain (fig. 3) at about 170 ka. These relations suggest a long-term northerly migration rate for the southern terminus of Cascades Arc volcanism of 15 to $20 \mathrm{~km}$ per million years (m.y.; 1.5 to $2 \mathrm{~cm}$ per yr) and a rate for at least the past 3 m.y. of about $10 \mathrm{~km}$ per m.y. ( $1 \mathrm{~cm}$ per yr). Detailed calculations of the extrusion rate for the Lassen segment of the arc have not been made, but the available data (Sherrod and Smith, 1990) suggest that the extrusion rate was significantly higher at 3-2 Ma than from $2 \mathrm{Ma}$ to the present.
Two independent tectonic regimes affect the Cascades Volcanic Arc in the Lassen area: the Basin and Range Province and the Walker Lane. The extensional Basin and Range Province is expanding westward into the Cascades Arc (Guffanti and others, 1990), and the active Hat Creek Fault and the Lake Almanor Graben are the westernmost major Basin and Range structures in the area (fig. 2). This impingement is manifested in numerous normal faults, many of which provide pathways for magma to reach the surface. Some magmas traverse the crust rapidly, and relatively primitive mafic lavas are widespread, albeit not abundant (Borg and others, 1997). Many volcanic vents are aligned along fault traces and partially to completely bury them. The Lassen area also sits on the northwest projection of the Walker Lane, a broad linear zone of distributed strike-slip faulting, parallel to and inboard (east) of the San Andreas Fault System. The Walker Lane accommodates about 20 percent of the relative motion between the North American and Pacific Plates (Unruh, 1995; Blakely and others, 1997; Unruh and others, 2003; Faulds and Henry, 2008). In the Lassen region, this regime generally manifests itself as a small strike-slip component on the dominantly normal faults. Although the Hat Creek Fault-Lake Almanor Graben structure crosses the eastern half of LVNP (Clynne and Muffler, 2010), few faults are mapped there. Expression of the faults is obscured by a combination of young volcanism and glaciation, and additional faults are likely to be concealed in the subsurface.

\section{Regional Volcanoes}

On a regional scale, Quaternary volcanism in the Lassen region has built a broad platform of overlapping and intercalated mafic to intermediate volcanoes. This platform comprises hundreds of coalescing small- to medium-size volcanoes (as large as a few cubic kilometers) consisting predominantly of basalt, basaltic andesite, and andesite. We refer to these as regional volcanoes and (or) regional lavas. A seismic-refraction experiment (Berge and Stauber, 1987) indicates that the young volcanic platform is $\sim 4 \mathrm{~km}$ thick in the active southernmost Cascades Arc.

Two distinct parental magmas and their derivatives contribute to the suite of regional lavas in the Lassen area: calc-alkaline basalt and low-potassium olivine tholeiite basalt (fig. 3; Borg, 1995; Borg and others, 1997; Clynne and Borg, 1997; Borg and others, 2002). Edifices containing both magma types are rare. Calcalkaline compositions are related to Cascades Arc magmatism and dominate the regional suite in both volume and abundance. Small calc-alkaline volcanoes are scoria cones with fields of lava flows, whereas large calc-alkaline volcanoes are steep-sided cones or shields with gentle slopes. Low-potassium olivine tholeiite (LKOT; elsewhere termed high-alumina olivine tholeiite or HAOT) basalt is a volumetrically minor but widespread 


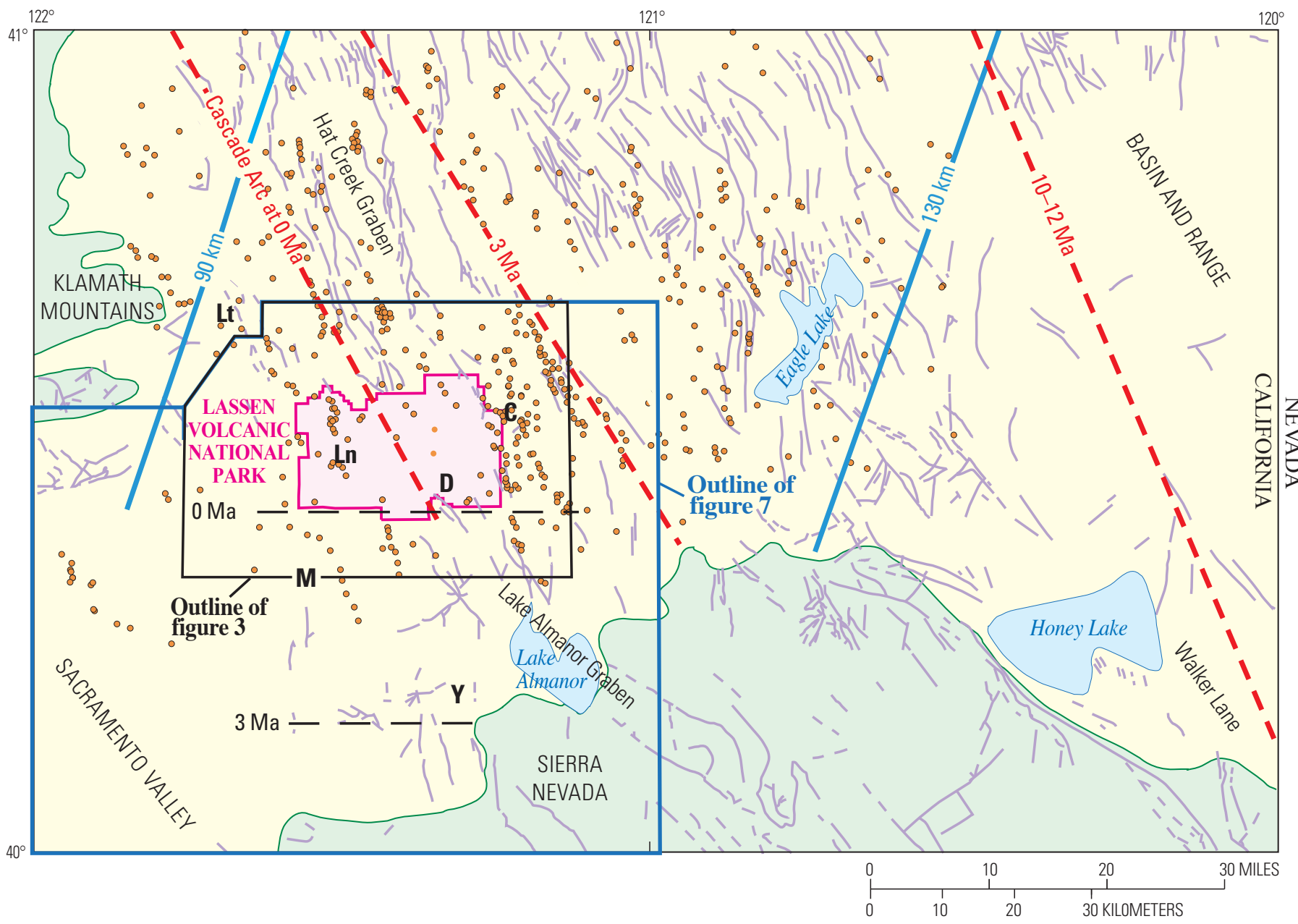

Figure 2. Map showing regional tectonic setting of area from Sacramento Valley to California-Nevada border, including Lassen Volcanic National Park and vicinity, California. Light-yellow background indicates late Tertiary to Holocene volcanic rocks of the Cascades Arc and the Basin and Range Province. Green background indicates Paleozoic to Mesozoic metamorphic-plutonic basement of the Sierra Nevada and Klamath Provinces (small outliers of volcanic rocks not shown). Orange dots indicate the location of volcanic vents younger than about $7 \mathrm{Ma}$ (older vents not shown). The large majority of vents are regional calc-alkaline volcanoes. Thin violet lines show the location of faults. Dashed red lines show the approximate position of the arc axis at the times indicated, and horizontal dashed black lines indicate the approximate southern terminus of arc volcanism at 0 and $3 \mathrm{Ma}$. At $\sim 12 \mathrm{Ma}$, the axis of the Lassen segment of the arc was near the California-Nevada border. Since then, the arc axis has migrated westward to its present position. Simultaneously, the width of the arc narrowed (Guffanti and others, 1990). Thick blue lines indicate the estimated present-day depth to the subducted Gorda Plate. C, Caribou Volcanic Field; D, Dittmar Volcanic Center; Ln, Lassen Volcanic Center; Lt, Latour Volcanic Center; M, Maidu Volcanic Center; Y, Yana Volcanic Center. Map taken from figure 5 of Clynne and Muffler (2010), as updated from Guffanti and others (1990).

component of the regional volcanism and is related to Basin and Range extension. LKOT basalt erupted from fissures between the shield volcanoes, and the fluid lavas flooded intervening valleys.

\section{Calc-Alkaline Volcanoes}

Regional calc-alkaline volcanoes have a wide range of sizes and forms that range-from scoria cones (commonly and locally called cinder cones) through steep-sided lava cones to broad shield volcanoes. Typically, lava flows of regional calc-alkaline volcanoes have blocky vesicular lava surfaces, although ' $a$ 'ā surfaces are also observed. Interiors have joint patterns that are thickly slabby to thinly platy. Aphanitic textures are typical, and holocrystalline textures are generally confined to thick or ponded flows.

The smallest and most abundant volcanoes are scoria cones, typically $50-200 \mathrm{~m}$ in height. Scoria cones are composed of bedded scoria and bombs piled up around a vent. Typically they have an associated lava flow that erupted from the base of the cone. Scoria cones have a single period of activity (that is, they are monogenetic). In this region they typically erupt small-volume, blocky to 'a'ā lava flows. Scoria cones are usually homogeneous in chemical composition and mineralogy, and they tend to occur in groups of similar age and lithology. 


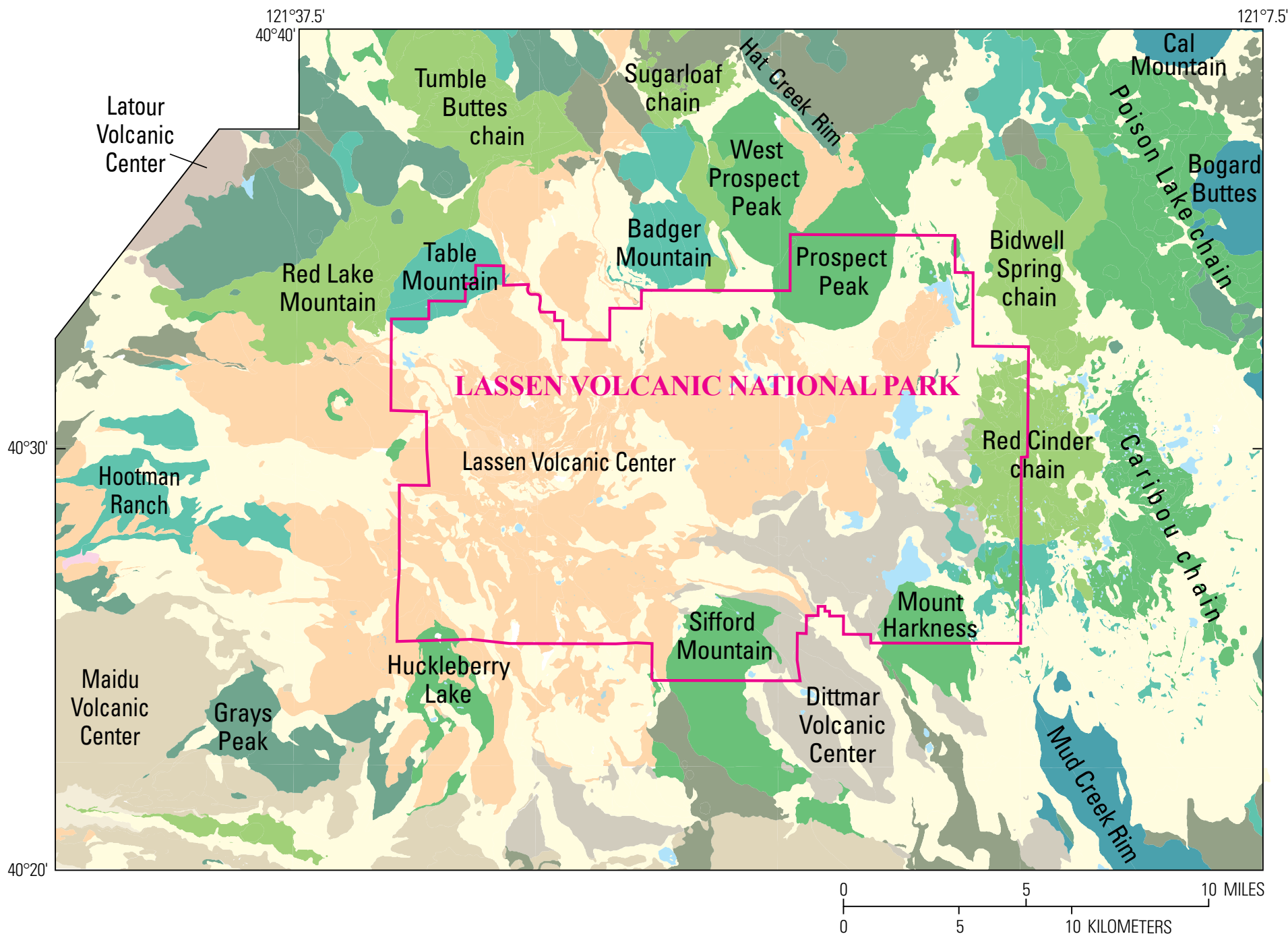

Figure 3. Map of Lassen

Volcanic National Park and vicinity emphasizing calc-alkaline and tholeiitic volcanic rocks that surround the Lassen Volcanic Center. Regional calc-alkaline rocks are divided into five age groups (from youngest to oldest, a-e) with age boundaries at $0.1,0.45,0.788$, and $1.810 \mathrm{Ma}$. Prominent calcalkaline edifices and chains are labeled. Light blue areas are lakes. Map adapted from figure $4 B$ of Clynne and Muffler (2010).

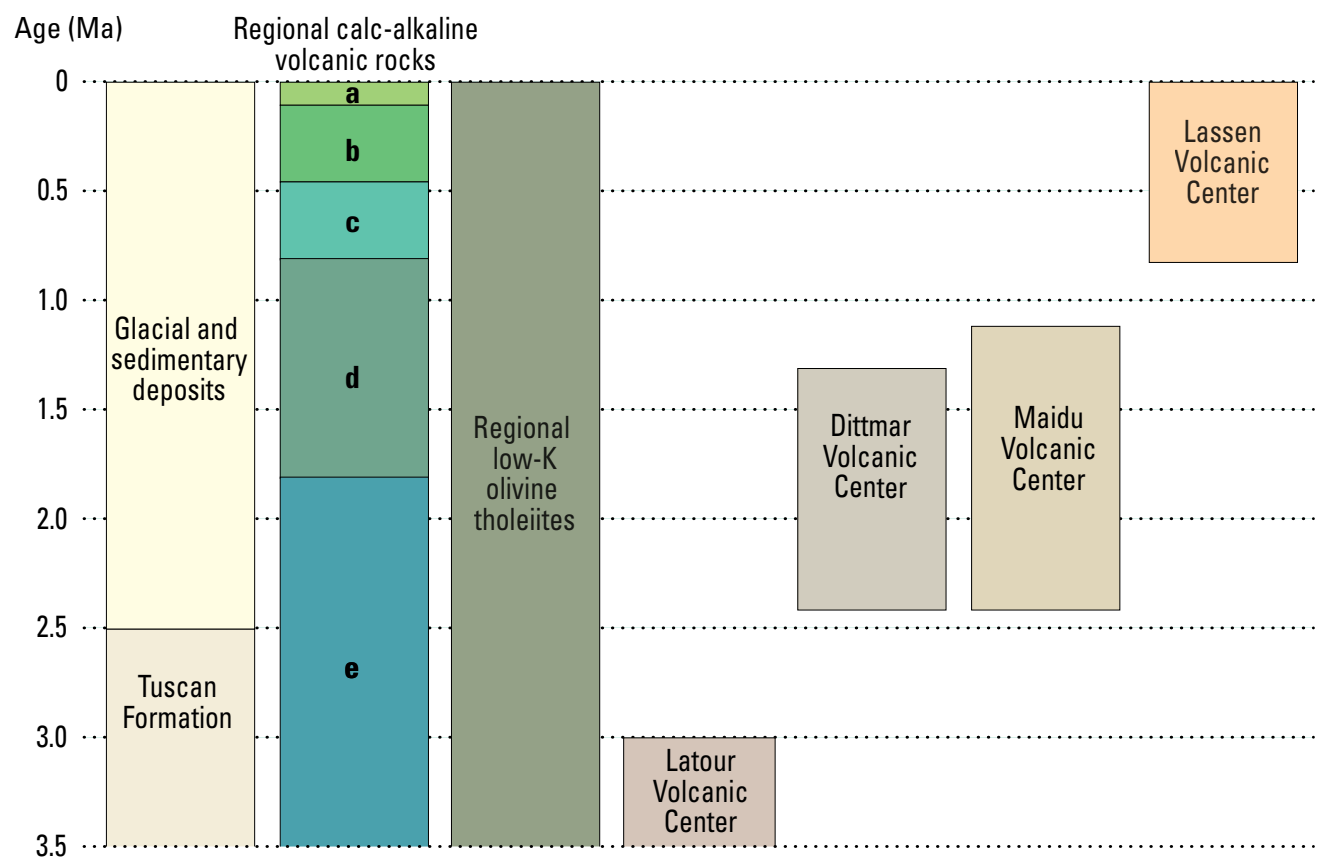


Lava cones and shield volcanoes are typically $300-800 \mathrm{~m}$ in height (bigger than scoria cones) and are more or less circular in plan view. Lava cones and shield volcanoes are constructed by eruptions from a central vent or flank vents high on the edifice that together build a steep-sided lava cone or a flatter shield volcano. They are commonly capped by a scoria cone, but generally lack widely distributed fragmental deposits. They have a single period of activity (monogenetic) or a period of intermittent activity as long as a few tens of millennia (polygenetic), and they build a variety of edifice sizes as much as a few cubic kilometers in volume. Lavas from the longer-lived, larger regional volcanoes (shields or lava cones) have a single chemical composition or display small compositional ranges throughout the lifetime of the edifice. If compositionally heterogeneous, they typically evolve with time to higher silica and crystal contents with accompanying changes in phenocryst assemblage.

The calc-alkaline regional suite is a continuum of olivine basalt, olivine-augite basaltic andesite, and two-pyroxene andesite; rocks more silicic than andesite are rare (fig. 4). Phenocryst assemblages are relatively simple. Primitive basalts contain olivine, commonly without a second phase. Evolved basalts add augite and plagioclase to the assemblage, and most basaltic andesites contain a combination of olivine, augite, and plagioclase phenocrysts. Complex zoning patterns, multiple populations of phenocrysts, and resorption or reaction features in phenocrysts are generally absent in mafic calc-alkaline rocks, but they are present in some andesites. Hypersthene replaces olivine in the fractionating assemblage in the range 56-58 percent $\mathrm{SiO}_{2}$, and most andesites contain both augite and hypersthene. Glomeroporphyritic clots of crystals, generally of the same phases as are present as phenocrysts in the rock, are common in evolved rocks of the calc-alkaline suite.

\section{Low-Potassium Olivine Tholeiite}

LKOT lava flows form widespread sheets that have a characteristic surface morphology. The upper and lower surfaces of flow units contain abundant spherical vesicles, and flow tops are often ropy (pāhoehoe) and have a characteristic joint pattern of crudely hexagonal blocks. Interiors of flow units are generally holocrystalline and often diktytaxitic; the flows are massive and display a pattern of widely spaced blocky joints. Upper flow surfaces have little relief except for common to abundant tumuli. These characteristics are rapidly obscured by weathering and soil-forming processes, so that, within about 400-500 k.y., LKOT flows in the Lassen area become flat surfaces with thick soils. Despite being volumetrically subordinate overall to calcalkaline volcanic products, volumes of individual LKOT flows are relatively large; volumes of as much as a few cubic kilometers are typical. LKOT flows were erupted from fissures that built spatter cones and ramparts; scoria cones are rare. These vents are inconspicuous in the geologic record because they are composed of glassy scoria that is easily weathered and eroded, and the lowrelief vent profiles are often buried by younger volcanic rocks. Vents for LKOT flows older than a few hundred thousand years are difficult to identify.

The LKOT suite displays remarkable chemical and petrographic homogeneity - almost all analyses contain
Figure 4. Graph of $\mathrm{K}_{2} \mathrm{O}$ content against $\mathrm{SiO}_{2}$ content of regional volcanic rocks in the Lassen area, showing $\sim 600$ analyses of calcalkaline rocks and low-potassium olivine tholeiite (LKOT) basalts less than about 3 million years old. The calc-alkaline rocks are dominantly medium- $\mathrm{K}_{2} \mathrm{O}$, as defined by Gill (1981), and most are basalt to andesite; rocks with more than about 63 weight percent $\mathrm{SiO}_{2}$ are sparse in the regional suite. The LKOT suite is chemically homogeneous at $48-50$ weight percent $\mathrm{SiO}_{2}$.

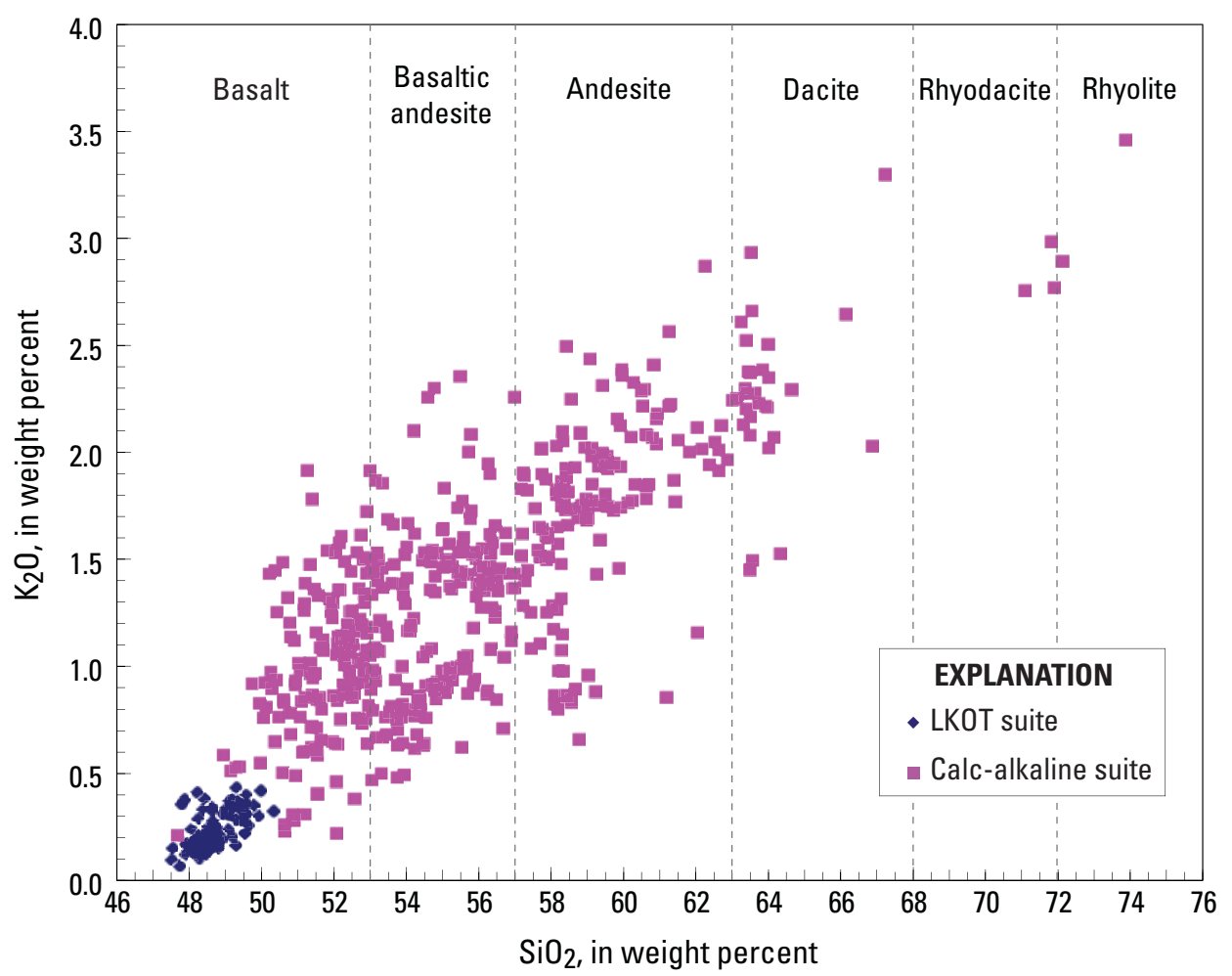


48-50 percent $\mathrm{SiO}_{2}$ (fig. 4). LKOT typically contains sparse olivine phenocrysts, accompanied by plagioclase in slightly more evolved examples. Augite phenocrysts and multiple phenocryst populations are rare, as are phenocrysts with strong zoning or resorption textures. Glomeroporphyritic clots of crystals, like those found in calc-alkaline rocks, are uncommon and generally are confined to near-vent parts of lava flows. The groundmass is usually completely crystalline, commonly with a diktytaxitic texture (small plagioclase, olivine, and augite crystals projecting into abundant tiny vesicles). See Borg and others (2002) for further description of the lithologic, petrographic, and distinctive geochemical characteristics of LKOT.

\section{Parental Magmas and Evolution of the Regional Suite}

A diverse array of mafic compositions is found in the Lassen region. These have been studied and modeled extensively, and only a brief summary of magma compositions and sources is given here. For additional discussion, see the references cited in Clynne and Muffler (2010).

The most striking feature of LKOT in the Lassen area is the limited range in major- and trace-element contents displayed by these lavas (Clynne, 1993; Bacon and others, 1997; Clynne and others, 2008). Distinctive features of LKOT from the Lassen region are low $\mathrm{SiO}_{2}(\sim 48-50$ weight percent), low alkali content, especially $\mathrm{K}_{2} \mathrm{O}(\sim 0.1-0.4$ weight percent), and low volatile content (Sisson and Layne, 1993). In general, their trace-element characteristics are like those of the midocean ridge basalts that are enriched in light rare-earth elements (E-MORB) (fig. 5). Strontium, neodymium, and other isotopic systematics of LKOT are distinct from those of calc-alkaline basalts (Bacon and others, 1997; Borg and others, 1997; Borg and others, 2000; Borg and others, 2002).

In contrast to LKOT, the calc-alkaline suite forms a compositional (fig. 4) and isotopic continuum. The calc-alkaline lava suite has geochemical characteristics typical of arc magmas erupted through continental crust, for example, like those in the Japan and Kamchatka Arcs (Gill, 1981). Geochemical diversity is greatest in the most primitive compositions, and fractionation reduces the range of geochemical diversity in more evolved rocks through interaction with the lower crust and mixing within the suite (Clynne, 1990; Bullen and Clynne, 1990; Hart and others, 2002). Evolution of mafic magmas is dominated by crystal fractionation, but addition of small-degree partial melts of mafic lower crust is also an important process (Clynne, 1993). Assimilation of upper crust also plays a role in determining the geochemical composition of some andesitic regional volcanoes. For the volcanic centers in the Lassen region, calcalkaline basalt is the parental magma.

The Lassen region contains primitive (unevolved) calcalkaline basalts and magnesian andesites that display a wide range of compositions with systematic variation across the arc. At one end of the spectrum are low-K $(0.3-0.8$ weight percent $\mathrm{K}_{2} \mathrm{O}$ ) basalts with low contents of incompatible elements and

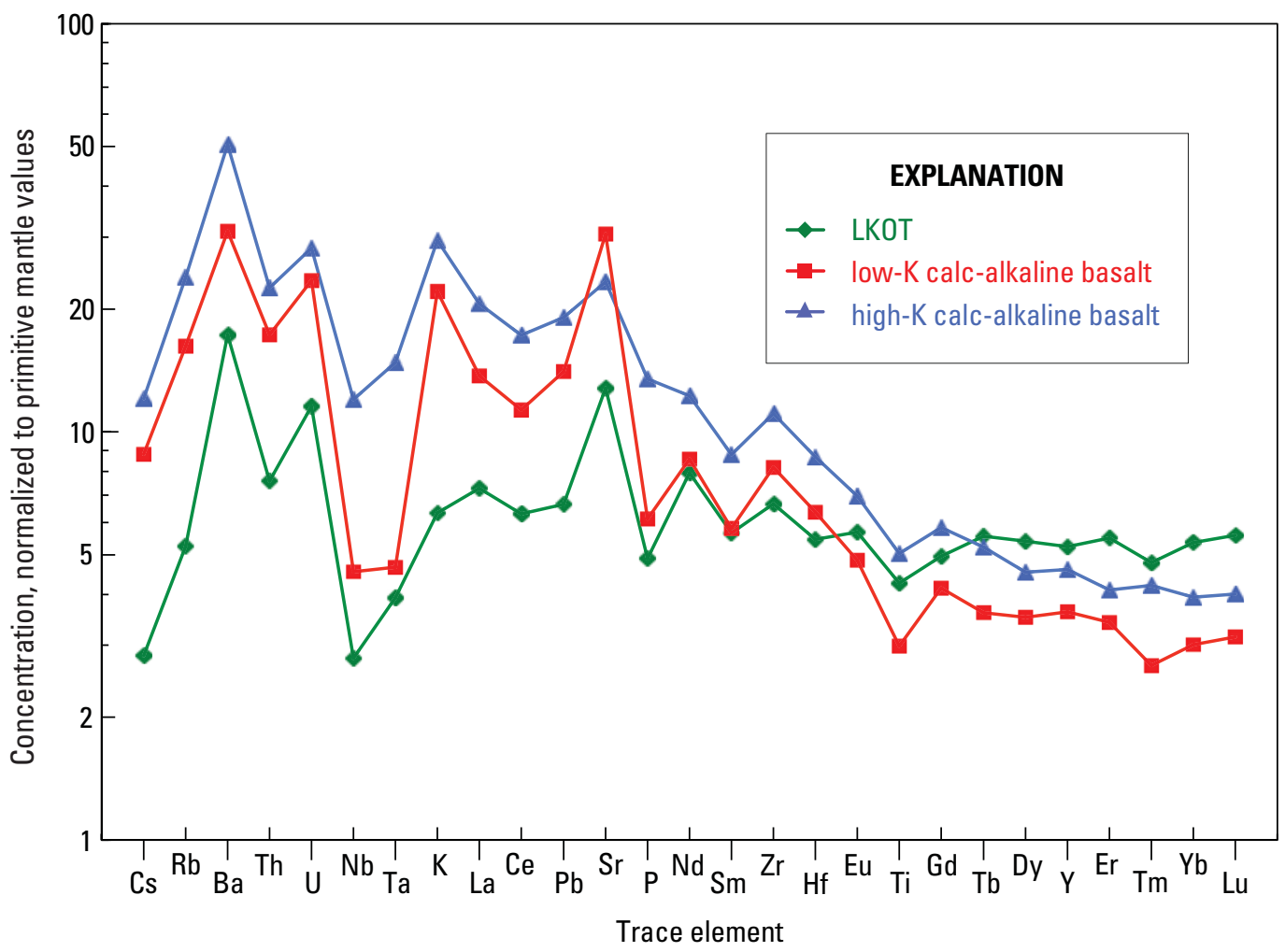

Figure 5. Multielement spider diagram showing concentrations of trace elements in primitive basalts of the Lassen region. Diagram shows the abundances of trace elements in the average compositions that produce the array of primitive basalts in the Lassen region, normalized to primitive mantle values (vertical axis) of Sun and McDonough (1989). Magnesian andesites (not shown) are essentially equivalent to the low-K calc-alkaline basalts, but have $\mathrm{SiO}_{2}>53$ percent, $\mathrm{Fe} 0 *$ $\mathrm{MgO}<1$, and slightly steeper patterns than low-K calcalkaline basalts. Low-potassium olivine tholeiites (LKOT) have lower overall abundances of incompatible elements, a smaller slab component, and higher concentrations of heavy rareearth elements. 
a strong arc geochemical and MORB-like isotopic signatures (Clynne, 1993; Bacon and others, 1997; Borg and others, 1997) that are present in the arc axis. The most extreme of these low- $\mathrm{K}_{2} \mathrm{O}$ rocks are actually primitive magnesian andesites found mostly in the forearc. At the other end of the spectrum are high-K $\left(0.8-2.0\right.$ weight percent $\left.\mathrm{K}_{2} \mathrm{O}\right)$ basalts with higher contents of incompatible elements, a weaker arc geochemical signature, and isotopic compositions similar to ocean-island basalts (Clynne, 1993; Bacon and others, 1997; Borg and others, 1997) that are found mostly in the backarc. The differences in basalt compositions lead to a model for magmagenesis in the Lassen region that explains the mineralogical, compositional, and spatial systematics of the lavas (fig. 6).

\section{Volcanic Centers}

Intercalated within the regional volcanic rocks are a few voluminous (as much as a few hundred cubic kilometers) and long-lived (0.5-1 m.y. or longer) foci of volcanism called volcanic centers (Clynne and Muffler, 2010). Volcanic centers erupt only calc-alkaline magmas but are compositionally diverse. The fundamental differences between regional calc-alkaline volcanoes and volcanic centers are the latters' greater longevity, volume, and range of compositions in a single edifice or geographic locale. Five volcanic centers younger than about 3.5 Ma have been recognized along the Cascades axis in the Lassen area (fig. 7). Although each volcanic center experienced a distinct evolution, that evolution generally consisted of an initial phase of silicic volcanism followed by construction of a large composite cone dominated by andesite, which is flanked by a variety of younger, more silicic rocks. Late in the evolution of each volcanic center, an acidic hydrothermal system, driven by heat from cooling subvolcanic silicic magma bodies, caused alteration of the permeable rocks of the composite cone. Subsequent glacial and fluvial erosion of the altered interiors of the composite cones resulted in bowl-shaped depressions surrounded by more resistant rims of thick, unaltered, flank lava flows. The Yana, Maidu, Dittmar, and Latour Volcanic Centers have reached this stage, and their hydrothermal systems

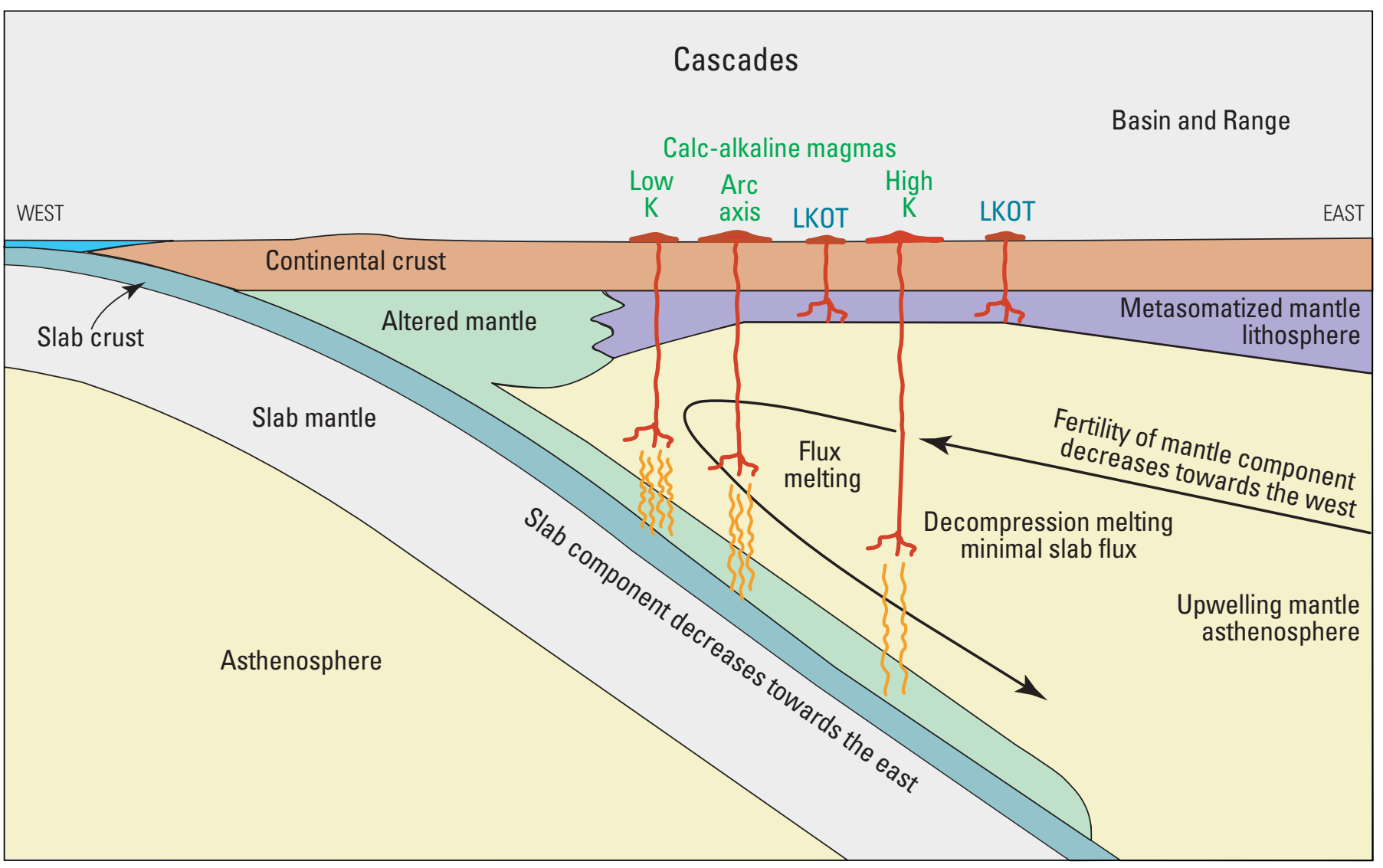

Figure 6. Diagrammatic cross section showing magmagenesis model for the Lassen region. The arc geochemical signature decreases from west to east across the arc, whereas the fertility (qualitative ability to produce basaltic melt) of the subarc mantle decreases from east to west. Calc-alkaline arc magmas in the rear arc have a weak slab signature and are generated by decompression melting of relatively fertile lherzolite. In contrast, calc-alkaline basalt magmas from the arc axis have a stronger slab signature and are generated by flux melting of relatively depleted Iherzolite. Some of the calc-alkaline magmas in the forearc are low-K magnesian andesites. These magmas have the strongest slab signature and are generated by flux melting of harzburgite. This model is consistent with mineralogy, major- and trace-element composition, isotope geochemistry, and spatial systematics of magmas in the Lassen area. Note that low-potassium olivine tholeiite (LKOT) comes from a much shallower depth, probably in the mantle lithosphere, than does the calc-alkaline basalt. 


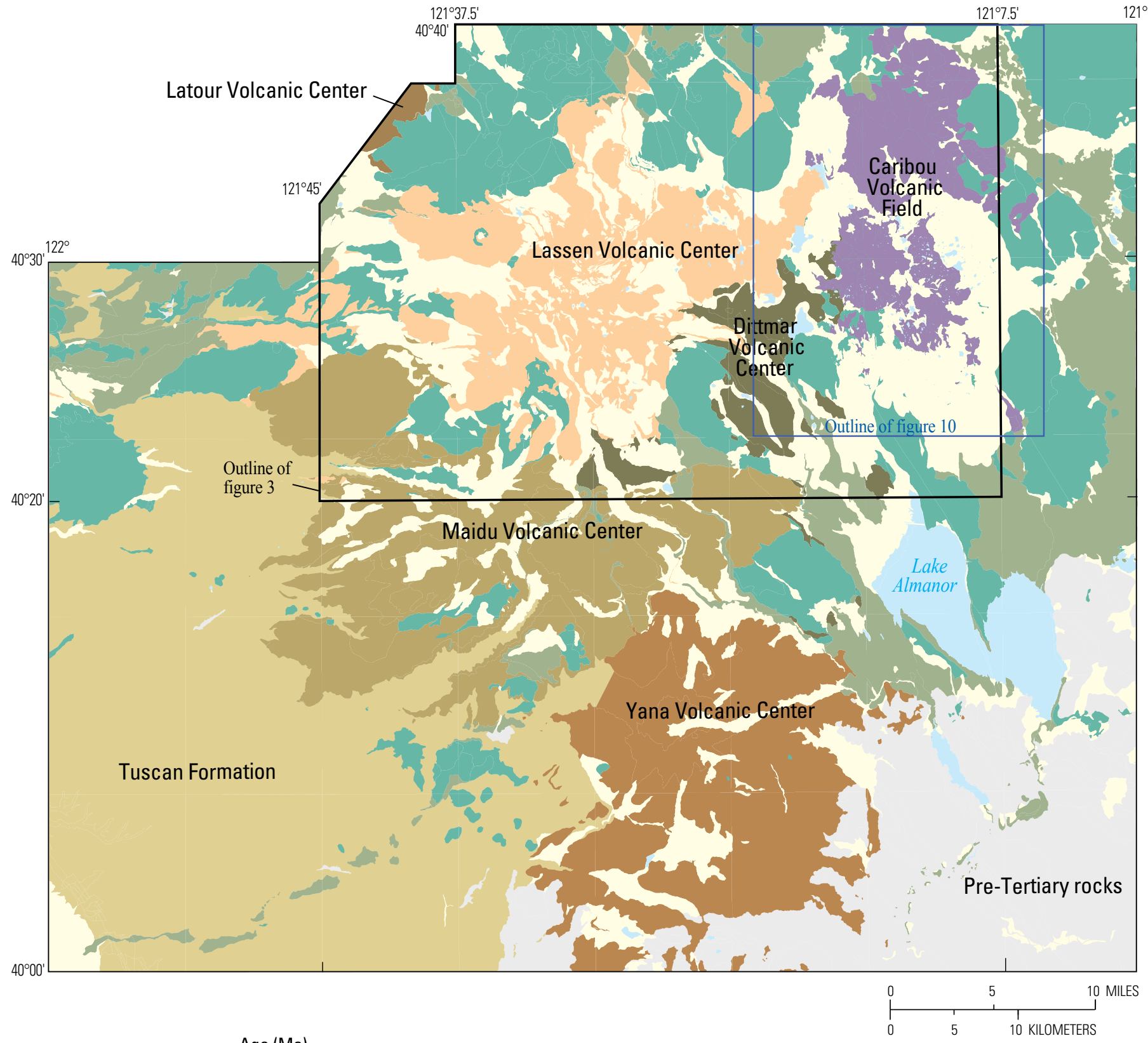

Figure 7. Map and chronostratigraphic chart of volcanic centers in the Lassen region. Generalized regional geologic map emphasizes the location, extent, and ages of large volcanic centers, including those in Lassen Volcanic National Park. Blue areas are lakes. Map adapted from figure $4 A$ of Clynne and Muffler (2010).
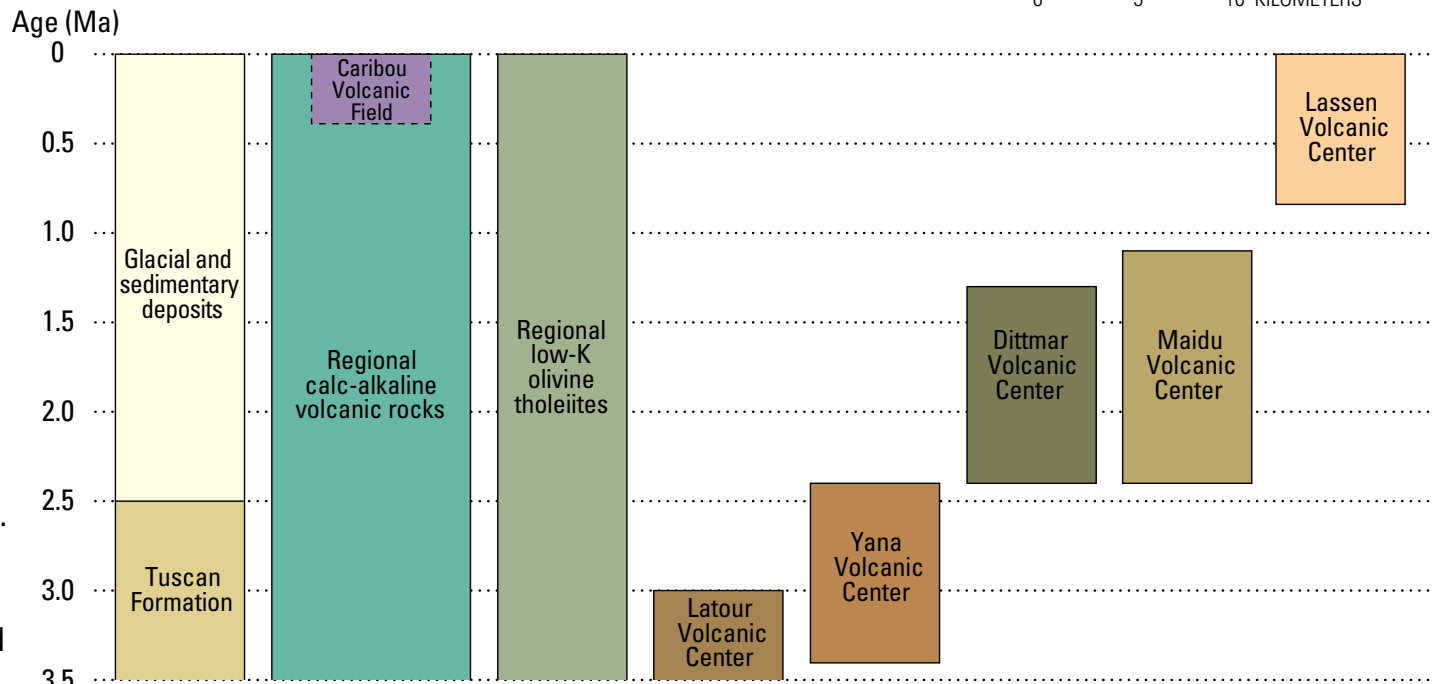
are extinct. The Lassen Volcanic Center (LVC) hosts continuing silicic volcanism and an active hydrothermal system (Muffler and others, 1982; Muffler and others, 1983; Ingebritsen and Sorey, 1985; Clynne and others, 2003; Janik and McLaren, 2010, Ingebritsen and others, 2016).

Volcanic centers (as defined by Clynne and Muffler, 2010) contain a diverse assemblage of rock types from basalt to rhyolite, but they are dominated by andesite and dacite. Andesites in volcanic centers evolve from regional calcalkaline mafic parental compositions by crystal fractionation and addition of a small crustal melt component (Clynne, 1990; Bullen and Clynne, 1990). Petrography of volcaniccenter andesites is much more complex than that of rocks from regional volcanoes, and geochemical and petrographic evidence for magma mixing is abundant. Phenocrysts commonly are larger and more abundant than in regional lavas of equivalent silica content. Multiple phenocryst populations, reverse and strong normal zoning, and abrupt changes in phenocryst compositions are typical of volcaniccenter rocks. Glomeroporphyritic clots of crystals, interpreted to be derived from bodies of cumulate material fractionated from parental and evolved mafic magmas, are abundant in volcanic-center andesites and attest to efficient recycling of crystals within the magmatic system. Dacites are characterized by very pronounced disequilibrium phenocryst assemblages. Coexisting populations of resorbed and unresorbed phenocrysts and unstable assemblages (for example, magnesian olivine plus quartz) are common, and quenched mafic magmatic inclusions are abundant.

Volcanic centers result from a local increase in the amount of basaltic magma intruded into the crust from the mantle relative to the background calc-alkaline regional volcanism (Guffanti and others, 1996). Increased basaltic intrusion heats the crust and promotes interaction between mafic magma and crustal rocks. A complex, vertically zoned magmatic system with localized bodies of magma develops in the crust beneath the volcanic center. Magma mixing among andesitic magma batches is common, and eventually the enhanced heat causes crustal melting beneath volcanic centers and interaction between mafic and silicic magma bodies, leading to eruption of intermediate and silicic lavas (Borg and Clynne, 1998). Geochemical diversity of rocks decreases with time in volcanic centers, attesting to the increasing importance of homogenization in the magmatic systems during their evolution (Clynne, 1990; Bullen and Clynne, 1990).

Volcanic centers are the surface expression of a magmatic cycle driven by a local increase in regional magmatic flux that waxes as the crust is heated and wanes as the easily fusible component of the lower crust is depleted. During the andesitic phase of volcanic centers, magmatic fractionation is dominated by crystal fractionation of basalt with a relatively small contribution from the crust. As the evolution of volcanic centers proceeds, the crustal component becomes increasingly important until, in the later stages, it dominates the magmatic system. The origin of the increased magmatic flux that initiates volcanic centers is unclear. It may be caused by structures that focus magma at the base of the crust or within the lower crust (Blakely and others, 1997). Alternatively, it could be related to inhomogeneities of magma production in the mantle wedge or even to heterogeneities at the slab-wedge interface. Volcanic centers do not significantly overlap in space, possibly as a result of the depletion of the easily fusible component in the lower crust that is required for production of large volumes of silicic magma. Volcanism in volcanic centers has been nearly continuous somewhere in the Lassen area over the past 3.5 m.y. Typically, a single volcanic center becomes extinct before or as the next center becomes active. During the early Pleistocene, however, the life spans of the Maidu and Dittmar Volcanic Centers coincided (fig. 7).

\section{Eruptive History of the Lassen Area}

\section{Regional Volcanic Rocks}

Over the past 3.5 m.y., regional calc-alkaline volcanism in the Lassen segment of the Cascades Arc constructed a broad platform of volcanic rocks in a band straddling the present arc axis (figs. 2 and 3). A variety of these older lavas, erupted from shield volcanoes, lava cones, and scoria cones, are exposed in the mostly unglaciated terrane surrounding the LVC. North and east of the LVC, these older rocks commonly are broken into linear blocks bounded by faults. The volume of calc-alkaline regional volcanic rocks diminishes with distance both east and west from the arc axis, so that there are lesser volumes of fore-arc and back-arc volcanism. On a time scale of 50,000 to 200,000 years, regional volcanism is concentrated in local areas. Regional volcanism does not occur within the boundaries of active volcanic centers, where rising mafic magmas are intercepted and processed and thus contribute to the magmatic system of the volcanic center. Return of regional volcanism within the boundaries of a volcanic center indicates solidification of that part of the center's magmatic system.

Within the regional lavas of the Lassen area are many young alignments of monogenetic cones and flows that share spatial, chemical, and lithologic characteristics. These are illustrated on this field trip by the Tumble Buttes, Sugarloaf, and Poison Lake chains (fig. 3).

LKOT is related to Basin and Range tectonics (Clynne, 1993), and it erupted across the Lassen region in a wave progressing from east to west that approximately coincides with progressive impingement of Basin and Range extension on the Cascades Arc (Guffanti and others, 1990). Although they produce relatively large volumes of lava, LKOT eruptions are relatively infrequent (Clynne and others, 2004), and, overall, LKOT is volumetrically subordinate to the dominant calcalkaline volcanism. Because LKOT lavas are readily buried by younger volcanism, some are likely hidden in the subsurface. 


\section{Yana and Latour Volcanic Centers and the Tuscan Formation}

The oldest volcanic rocks in the vicinity of the present-day axis of the Cascade Range in the Lassen area make up the Yana and Latour Volcanic Centers. Rocks of the Yana Volcanic Center ( 3.4-2.4 Ma) dominate the area southwest of Lake Almanor, whereas rocks of the Latour Volcanic Center ( $>3 \mathrm{Ma})$ are present northwest of LVNP. The evolution of the Yana Volcanic Center is understood in only a general sense, and even less is known about the Latour Volcanic Center. The Yana and Latour Volcanic Centers are dominantly andesitic, and the lithologies are similar to the better-known volcanic centers described below.

The Yana and Latour Volcanic Centers are important, however, as the primary sources of the Tuscan Formation (fig. 7), a broad volcanic and volcaniclastic wedge of fragmental material emplaced on the west slope of the southernmost Cascade Range (Anderson, 1933; Lydon, 1968; Helley and others, 1981; Helley and Harwood, 1985). The Tuscan Formation consists primarily of volcanic debris-flow deposits, conglomerate, sandstone, and siltstone, with minor silicic ashflow and air-fall tuffs and sparse basaltic to andesitic lava flows. The Tuscan Formation originally covered about $5,000 \mathrm{~km}^{2}$ and had a volume of $1,200 \mathrm{~km}^{3}$ (Lydon, 1968). Adjacent to the Cascade Range, the Tuscan Formation is $\sim 500 \mathrm{~m}$ thick (Lydon, 1968) where it interfingers with proximal deposits of the Latour and Yana Volcanic Centers. It thins dramatically in distal areas to the west in the Sacramento Valley, where volcanic debris was reworked by fluvial processes (Harwood and others, 1981) and intercalated with fluvial sediments. The Tuscan Formation ranges in age from $\sim 3.5 \mathrm{Ma}$ (Helley and others, 1981; Helley and Harwood, 1985) to perhaps as young as $\sim 2.5 \mathrm{Ma}$. In some places, the uppermost part of the Tuscan Formation may be derived from the Dittmar Volcanic Center.

The Nomlaki Tuff Member of the Tuscan Formation is a dacitic ash flow tuff of regional extent found intercalated with the lower part of the Tuscan Formation in the northern Sacramento Valley. The Nomlaki Tuff Member was dated at about 3.3 Ma by Evernden and others (1964). Distal Nomlaki Tuff Member is widely found in the western United States, and its volume is probably in the range of $75-100 \mathrm{~km}^{3}$. The Nomlaki Tuff Member thickens dramatically towards the Latour Volcanic Center, its likely source, but no caldera has yet been located.

\section{Dittmar Volcanic Center}

The Dittmar Volcanic Center (2.4-1.3 Ma) lies at the northwest end of the Lake Almanor Graben (figs. 2 and 7). The volcanic center has been chopped into a number of fault blocks, and detailed stratigraphy cannot generally be traced across the faults or correlated among blocks. Consequently, the details of the center's evolution are poorly known. The Dittmar Volcanic Center hosted a hydrothermal system in its waning stages of activity; thus many of the early Dittmar rocks are hydrothermally altered. Glaciation of weak, hydrothermally altered rocks has deeply eroded the central area, and rocks are generally poorly exposed. Deposits of the Dittmar Volcanic Center are grouped into three stratigraphic stages (Clynne and Muffler, 2010): Stage 1, early growth of the composite cone; Stage 2, later growth of the composite cone; and Stage 3, late silicic volcanism. The durations and ages of all three stages are poorly constrained. See Muffler and Clynne (2015) for more information about the Dittmar Volcanic Center.

\section{Maidu Volcanic Center}

The Maidu Volcanic Center (2.4-1.2 Ma) is located southwest of LVNP (fig. 7), where it unconformably overlies the Tuscan Formation and rocks of the Yana Volcanic Center (Clynne and Muffler, 2010). The summit and vent areas have been completely obscured by a combination of hydrothermal alteration and glacial and fluvial erosion. Although deeply eroded, the center is, in general, structurally intact. The total volume erupted was in excess of $200 \mathrm{~km}^{3}$. Like the other older volcanic centers, deposits of the Maidu Volcanic Center are grouped into three stratigraphic stages: Stage 1, early growth of the composite cone; Stage 2, later growth of the composite cone; and Stage 3, late silicic volcanism. See Muffler and Clynne (2015) for more information about the Maidu Volcanic Center.

\section{Lassen Volcanic Center}

The major stratigraphic divisions of the LVC are designated as the Rockland caldera complex, Brokeoff Volcano, and the Lassen domefield (fig. 8; Clynne and Muffler, 2010). These eruptive stages are contiguous periods of lithologically correlated volcanism distinctly different from one another but linked by a common magmatic system.

Rocks of the Lassen Volcanic Center range from basaltic andesite to rhyolite but are dominated by andesite and dacite (fig. 9).

The rate of eruption for the Lassen domefield appears to be significantly less than for the Rockland caldera complex and Brokeoff volcano. The Rockland caldera complex erupted $\sim 80 \mathrm{~km}^{3}$ of magma over its $\sim 215$-k.y. lifetime, a long-term average of $\sim 0.4 \mathrm{~km}^{3} / \mathrm{k}$.y. Brokeoff Volcano also erupted $\sim 80 \mathrm{~km}^{3}$ of magma over its $\sim 205$-k.y. lifetime, again a long-term average of $\sim 0.4 \mathrm{~km}^{3} / \mathrm{k}$.y. In contrast, the Lassen domefield erupted only $\sim 40 \mathrm{~km}^{3}$ over its 315-k.y. lifetime, a long-term average of $\sim<0.15 \mathrm{~km}^{3} / \mathrm{k}$.y. This output, however, was interrupted by a hiatus of 100 k.y. between $190 \mathrm{ka}$ and $90 \mathrm{ka}$. The rate for the Lassen domefield both before and after the hiatus was $\sim 0.2 \mathrm{~km}^{3} / \mathrm{k}$.y. All of these estimates are unavoidably approximate.

Inspection of the well-preserved youngest volcanic activity of the Lassen domefield, however, suggests that 


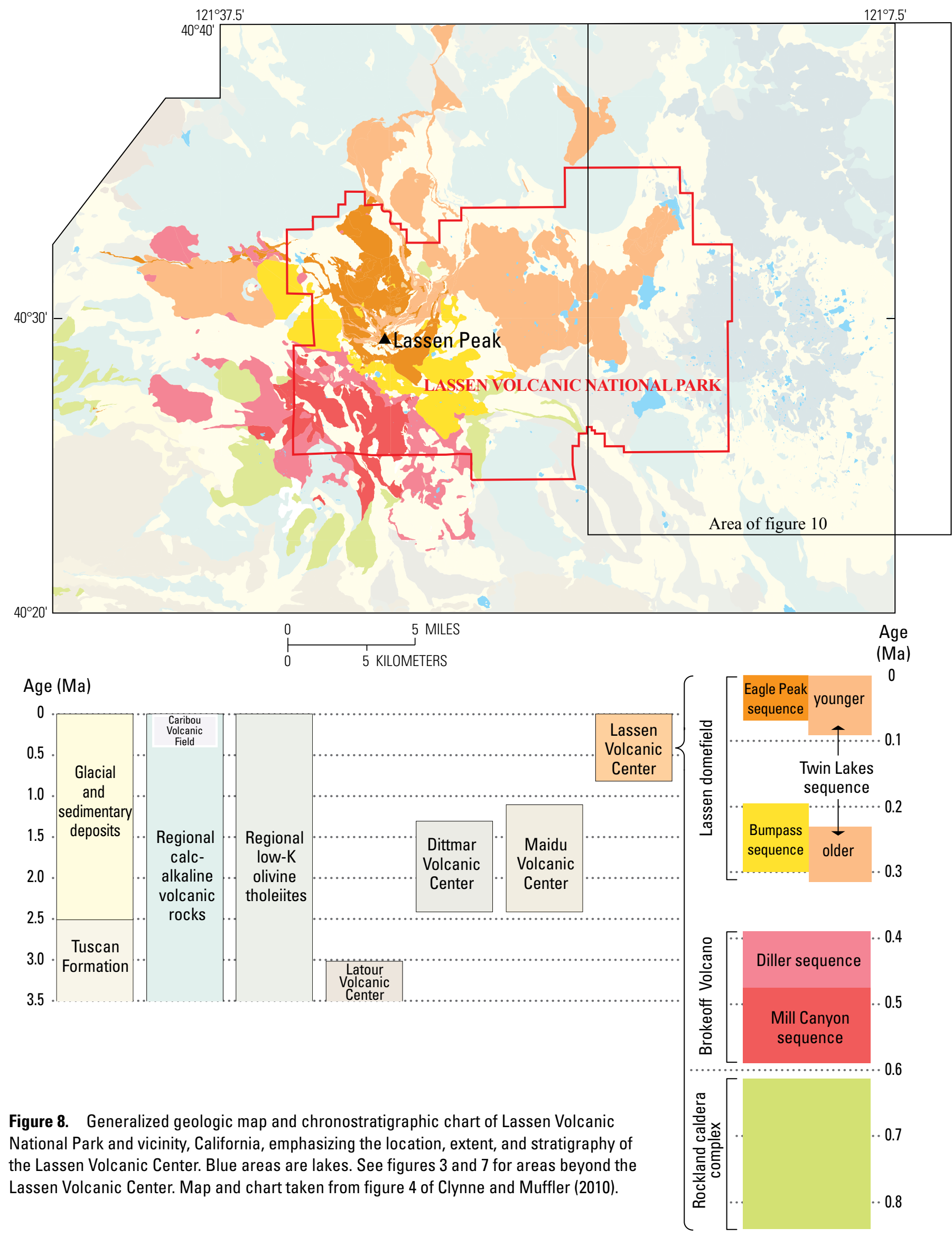




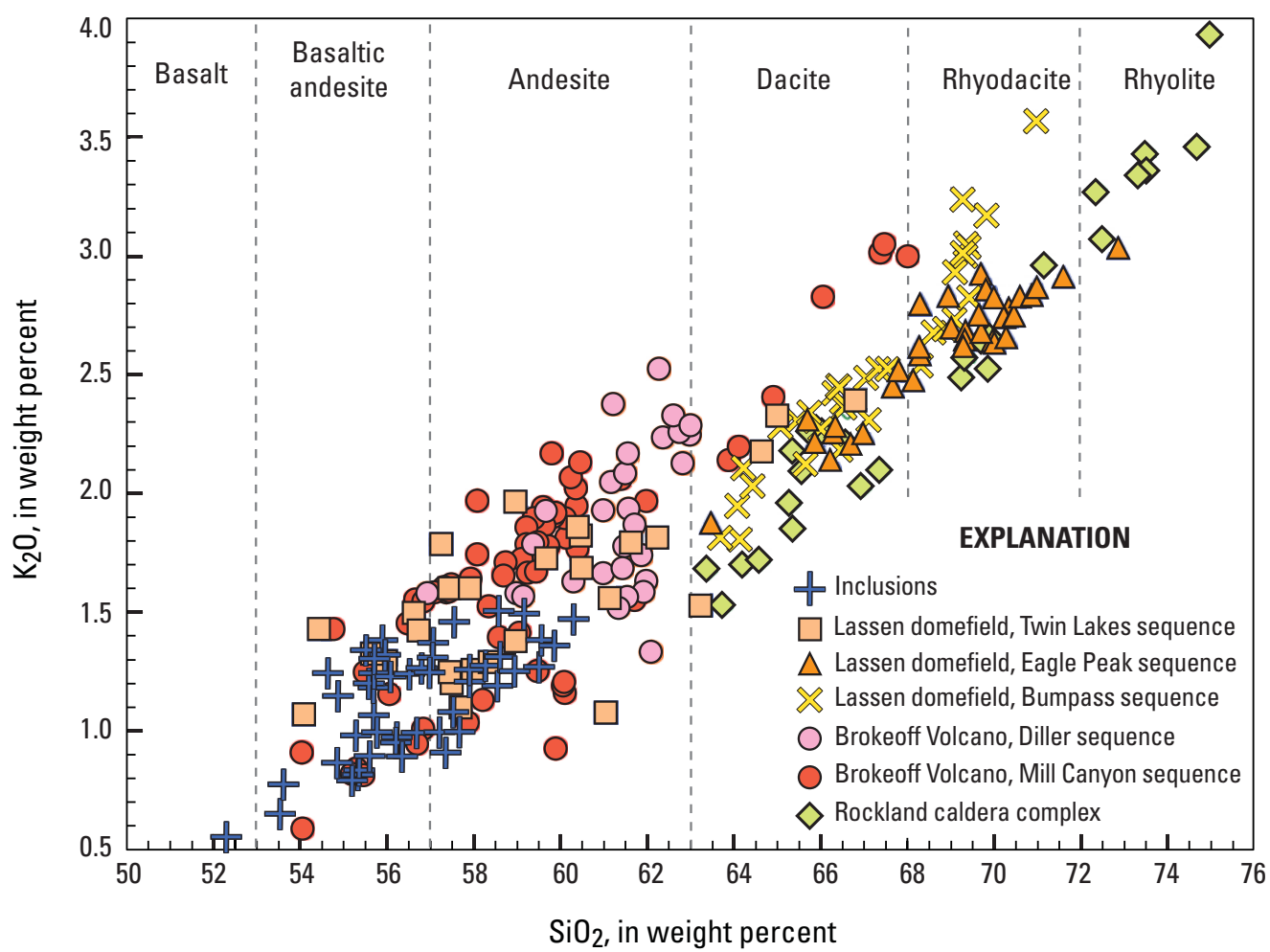

Figure 9. Graph of $\mathrm{SiO}_{2}$ content versus $\mathrm{K}_{2} \mathrm{O}$ content for 250 analyses of volcanic rocks from the Lassen Volcanic Center grouped by eruptive sequence. The Rockland caldera complex is dominated by dacite to rhyolite, Brokeoff Volcano is dominated by andesite, and the Lassen domefield (Bumpass, Eagle Peak, and Twin Lakes sequences) is dominated by dacite to rhyodacite. Basalt input is expressed as quenched mafic inclusions in the Bumpass and Eagle Lake sequences and as andesitic hybrid lavas of the Twin Lakes sequence (Clynne, 1990; Bullen and Clynne, 1990). volcanic activity probably occurs in short episodes separated by longer quiescent intervals, so that the short-term eruptive rate is variable. For example, the three eruptions at LVC in the Holocene (the past 11,700 years) total $\sim 2 \mathrm{~km}^{3}$, giving an eruptive rate of $\sim 0.17 \mathrm{~km}^{3} / \mathrm{k}$.y., similar to the long-term rate of the Lassen domefield. All three eruptions, however, occurred within the past 1,100 years, making the eruptive rate during this short period much higher $\left(\sim 1.8 \mathrm{~km}^{3} / \mathrm{k}\right.$.y. $)$.

\section{Rockland Caldera Complex}

The Rockland tephra was first recognized by Wilson (1961) as the "Rockland rhyolite pumice tuff breccia." A coeval distal ash-fall deposit is widely distributed in northern and central California, northeast to Idaho, and in deep-sea cores collected off the northern California coast (SarnaWojcicki and others, 1985).

Wilson (1961), Helley and others (1981), and Meyer and others (1991) attributed the Rockland deposits to the Maidu Volcanic Center; indeed, Helley and others (1981) called the unit the "ash of Mount Maidu." Clynne (1984) recognized that the Rockland deposits were younger than the Maidu Volcanic Center and, on the basis of a fission-track age of $\sim 400 \mathrm{ka}$ (Meyer and others, 1980, 1991), attributed the Rockland tephra to the LVC. This fission-track age was younger than Brokeoff Volcano, and, thus, the Rockland tephra was thought possibly to be the initial eruption of the Lassen domefield of the LVC. Subsequent precise dating determined the Rockland tephra to be $609 \pm 7 \mathrm{ka}$ (Lanphere and others, 1999, 2004), slightly older than Brokeoff Volcano. The calculated volume of the Rockland tephra is $\sim 50 \mathrm{~km}^{3}$ (dense rock equivalent; Sarna-Wojcicki and others, 1985), which is similar to that of the Mazama ash from Crater Lake (Bacon, 1983). An eruption of this magnitude must have formed a collapse caldera. Projection of the outcrop pattern of proximal deposits points towards Brokeoff Volcano, and it seems likely that eruption of the Rockland tephra produced a small caldera that has subsequently been filled by Brokeoff Volcano and younger products of the LVC.

Clynne (1984) also recognized a number of silicic rock units older than Brokeoff Volcano and the Rockland tephra, and he assigned them to the Maidu and Dittmar Volcanic Centers. Subsequent radiometric dating and improved understanding of the evolution of the Maidu and Dittmar Volcanic Centers showed these silicic rock units to be unrelated to those centers. Instead, these silicic rock units form a ring around the inferred source of the Rockland tephra and, thus, are now grouped with the Rockland tephra as the Rockland caldera complex (Clynne and Muffler, 2010). Lithic fragments from several of these silicic rock units are present in the Rockland tephra. These relations support our hypothesis that the Rockland tephra was erupted from a caldera located at the present site of Brokeoff Volcano. 


\section{Brokeoff Volcano}

Brokeoff Volcano, also designated "Mount Tehama" by the National Park Service, consists of a large, $80-\mathrm{km}^{3}$, composite volcano. Almost immediately after eruption of the Rockland tephra, its caldera began to fill as renewed activity formed Brokeoff Volcano. Clynne and Muffler (2010) describe the stratigraphy of Brokeoff Volcano as two sequences of deposits: the Mill Canyon sequence and the Diller sequence.

The Mill Canyon sequence consists of dozens of smallvolume basaltic andesite to dacite lava flows and interbedded fragmental deposits erupted from a central vent between about 590 and $470 \mathrm{ka}$. The sequence is dominated by packages of thin andesite lava flows and monolithologic breccias. Adjacent flow packages are of different lithologies, and a wide variety of porphyritic olivine and pyroxene basaltic andesites and andesites to pyroxene-hornblende dacites are present. The Mill Canyon sequence is capped by thick dacite lava flows erupted at $470 \mathrm{ka}$ (the dacite of Twin Meadows). This dacite is the only rock unit of significant lateral extent in Brokeoff Volcano and provides a convenient stratigraphic boundary between the Mill Canyon sequence and the overlying Diller sequence.

The Diller sequence consists primarily of six thick, large-volume, lithologically similar lava flows that erupted from flank vents between 470 and $385 \mathrm{ka}$. These flows consist of porphyritic augite-hypersthene andesite to silicic andesite and generally lack interbedded pyroclastic deposits. The lithologic, petrographic, and geochemical characteristics of the Mill Canyon and Diller sequences indicate a change in the Brokeoff Volcano magmatic system between those periods. During Mill Canyon time, evolving magma batches were small and temporally or physically isolated so that a diversity of lithologies was erupted. In contrast, during Diller time, the magmatic system was more integrated, and more voluminous lavas of relatively constant composition were erupted.

Williams (1932) proposed that the eroded core of Brokeoff Volcano was a collapsed caldera. Our mapping, however, has failed to reveal either caldera-bounding faults or any pyroclastic deposit that could be related to a caldera. The eviscerated core of Brokeoff Volcano appears to be the product of glacial and fluvial erosion of weak, hydrothermally altered rock, and much of the core area now consists of material emplaced by landslides (see figure 19 of Clynne and others, 2012). The largest remnants of Brokeoff Volcano (Brokeoff Mountain and Mount Diller) were protected from erosion by thick, unaltered, lava flows of the Diller sequence on their outer flanks.

\section{Lassen Domefield}

No volcanism is recognized in the LVC between about 385 and $315 \mathrm{ka}$. After this hiatus, the character and locus of volcanism in the LVC changed dramatically from the andesitic stratocone to the Lassen domefield, which consists of a core of dacite domes partly surrounded by hybrid andesite flows. The dacite domes erupted along the northern flank of Brokeoff Volcano and are divided on the basis of age into the Bumpass ( $\sim 300-190 \mathrm{ka})$ and Eagle Peak ( $70-0 \mathrm{ka})$ sequences. The hybrid andesite units erupted in two groups called the older $(\sim 315-240 \mathrm{ka})$ Twin Lakes sequence and the younger ( $90-0 \mathrm{ka})$ Twin Lakes sequence, which are contemporaneous with the Bumpass and Eagle Peak sequences, respectively. No volcanism is known in the LVC during the period 190-90 ka.

The Bumpass sequence is a group of 15 dacite to rhyodacite lava domes and flows emplaced between $\sim 300 \mathrm{ka}$ and $\sim 190 \mathrm{ka}$ as a broad curvilinear array in the southern part of the Lassen domefield. Repeated glaciation has removed glassy dome carapaces and most of the fragmental deposits associated with domes and flows; only a single lithic pyroclastic-flow deposit is preserved. Lavas of the Bumpass sequence are mostly porphyritic pyroxene and hornblende dacite; quartz and biotite are generally sparse. A few lavas are porphyritic biotite-hornblende rhyodacite. Quenched mafic inclusions (enclaves) are sparse to abundant. The Bumpass sequence is characterized by disequilibrium phenocryst assemblages that originated by mixing of a small proportion of regional mafic magma with rhyodacite of the Lassen domefield magmatic system.

The Eagle Peak sequence comprises seven units of dacite and rhyodacite lava domes and flows and their associated pyroclastic deposits that erupted in the north part of Lassen domefield. These include the two most prominent young volcanic features in LVNP: Lassen Peak ( $27 \pm 1 \mathrm{ka})$ and Chaos Crags $(1,103 \pm 13 \mathrm{ka} ; \sim 850$ C.E. $)$, as well as the products of five older eruptions. All units of the Eagle Peak sequence excepting Chaos Crags were glaciated, but the degree of glacial erosion is much less than on domes of the Bumpass sequence, and significant portions of glassy carapaces, primary hot talus, and pyroclastic deposits are preserved. Lavas of the Eagle Peak sequence are porphyritic hornblende and biotite dacite and rhyodacite; some also contain quartz. Like the Bumpass sequence, the Eagle Peak sequence is characterized by disequilibrium phenocryst assemblages and quenched mafic inclusions that originate by mixing of a small proportion of regional mafic magma with rhyodacite of the active Lassen domefield magmatic system.

The Twin Lakes sequence consists of two groups of mostly andesite and basaltic andesite lava flows and agglutinate cones erupted around the periphery of the Lassen domefield, but primarily on the Central Plateau of LVNP. The older group of lava flows is correlative with the Bumpass sequence, and the younger group is correlative with the Eagle Peak sequence. The two youngest eruptions in LVNP, the basaltic andesites of Cinder Cone and deposits of the 1914-17 eruption of Lassen Peak, are parts of the younger Twin Lakes sequence. Rocks of the Twin Lakes sequence have pronounced disequilibrium phenocryst assemblages that are characterized by coexistence of magnesian olivine and quartz. Except for Cinder Cone (see detailed description at Stop G-3 of Muffler and Clynne, 2015), the rocks originate by mixing of subequal proportions of regional mafic magma and rhyodacite of the Lassen domefield magmatic system. 
The Bumpass, Eagle Peak, and Twin Lakes sequences belong to a suite of lavas formed by a continuum of magmamixing processes between a basaltic component equivalent to the regional basaltic volcanism and a rhyolitic component generated by partial melting of solidified basalt underplated or intruded into the lower crust (Borg and Clynne, 1998; Feeley and others, 2008a). Compositional variation of the Bumpass sequence (and the earlier Rockland caldera complex) is dominated by the felsic melt. The youngest Lassen dacites (Eagle Peak Sequence) evolved by introduction of regional mafic magma into a reservoir containing residual felsic melt and phenocrysts that was probably too cool and viscous to erupt. Mixing of hot mafic magma and its phenocrysts with the cooler crystal mush, partial resorption of phenocrysts in the host dacite, quenching of the resultant mixed magma to form undercooled inclusions, and circulation and disaggregation of inclusions back into the host dacite created complex disequilibrium phenocryst assemblages (Clynne, 1999). Phenocryst abundance, character, and even assemblage can vary within individual dacite domes, and intradome variability can be as large as interdome variability. The two fundamental factors controlling the character of the erupted magma are the relative proportions of mafic and silicic components in the mixture and the length of time between the mixing event(s) and eruption. When the relative proportions of mafic and silicic components approach unity, inclusions are no longer formed, and the magmas mix homogeneously to form hybrid magmas. Hybrids of the Twin Lakes sequence are typically andesitic in bulk composition and are usually characterized by strongly resorbed phenocrysts and the coexistence of magnesian olivine and quartz as phenocrysts.

\section{Holocene Volcanic Activity}

The LVC is still active, and three eruptions have occurred in the Holocene: Chaos Crags, Cinder Cone, and the 1914-17 eruption at the summit of Lassen Peak. Chaos Crags is part of the Eagle Peak sequence, whereas Cinder Cone and the eruption at the summit of Lassen Peak are part of the younger Twin Lakes sequence. No other Holocene eruptions have been documented in the Lassen region.

Chaos Crags, located northwest of Lassen Peak, erupted at 1,103 \pm 13 years B.P. ( $~ 850$ C.E.; Clynne and others, 2002$)$ and is the youngest unit of the Eagle Peak sequence. As mapped by Christiansen and others (2002), the eruptive sequence consists of a group of six rhyodacite lava domes and associated pyroclastic deposits that define a typical silicic eruption in the LVC. Chaos Crags lavas are porphyritic hornblende-biotite rhyodacite that contains a complex disequilibrium phenocryst assemblage characteristic of Lassen dacites (Clynne, 1999). Quenched mafic inclusions are sparse to rare in the early rhyodacite lavas (generally less than 1 percent to a few percent), whereas they form as much as 20 percent of the late rhyodacite lavas.

Cinder Cone, located in the northern part of LVNP, is the youngest mafic volcano in the Lassen region and the second youngest eruption in the Twin Lakes sequence. Radiocarbon, stratigraphic, paleomagnetic, and dendrochronologic data (Clynne and others, 2000a, 2002; Sheppard and others, 2009) indicate that Cinder Cone erupted in 1666 C.E., not in 1851 C.E. as cited in earlier literature going back to Harkness (1875). Cinder Cone consists of five lava flows of basaltic andesite to andesite composition, two nested scoria cones, and a widespread mafic ash-fall deposit.

The 1914-17 eruption of Lassen Peak is the most recent eruption in the Twin Lakes sequence. It comprises a complex eruptive sequence consisting of a dacite dome and lava flow, dacite pyroclastic flow and fall deposit, and phreatic, avalanche, debrisflow, and flood deposits (Clynne and others, 2014; Christiansen and others, 2002; Clynne, 1999). The eruptive sequence began on May 30, 1914, with a phreatic explosion at the summit of Lassen Peak. By mid-May of 1915, more than 180 steam explosions had blasted out a 300-m-long crater at the summit. Magmatic activity was confined to the period from about May 14 to May 22, 1915, and affected primarily the northeast flank and slope of Lassen Peak (the Devastated Area) and the valleys of Lost and Hat Creeks as far as about 30 miles $(50 \mathrm{~km})$ downstream. Rock types range from olivine andesite to several varieties of hornblende-biotite dacite with abundant quenched mafic inclusions and complex mineralogy. Spectacularly banded pumice blocks, ejected in the May 22 subplinian eruption, serve to distinguish the May 22 deposits from those of May 14-19.

\section{Caribou Volcanic Field}

The Caribou Volcanic Field (CVF) is an area of intense, young regional volcanism located $20-30 \mathrm{~km}$ east of the LVC (figs. 7 and 10). The field is composed of monogenetic scoria cones, flows, and small- to medium-size lava cones, generally of mafic composition, and is distinguished from older regional mafic lavas around its periphery by substantial constructional morphology and the absence of significant structural disruption. The CVF ( 425-15 ka) is contemporaneous with the later part of the LVC and is the result of a higher flux of magma from the mantle compared to the Lassen segment of the arc as a whole, but not as high as that at the LVC (Guffanti and others, 1996). The CVF may represent an incipient volcanic center that is not quite vigorous enough to initiate crustal melting and silicic volcanism. No single edifice has a long history of activity. CVF volcanoes erupted in nine arrays discriminated by spatial, temporal, and compositional characteristics. Some arrays were active for only a few thousand years (for example, the Poison Lake chain), whereas several others (such as the Caribou chain) were active for periods as long as 100-200 k.y. Emplacement of arrays is generally structurally controlled; that is, linear arrays of vents bury active or inactive faults that provided pathways exploited by ascending magma and acted to focus volcanism at the surface.

The older part of the CVF consists of the Caribou chain (425-275 ka) - a large, extensively glaciated massif that dominates the Caribou Wilderness, just east of LVNP — and 4 contemporaneous groups of volcanoes peripheral to the Caribou chain (Cone Lake chain, Sunrise Peak sequence, Beauty Lake sequence, and Island Lake sequence) that range in age from 450 to $200 \mathrm{ka}$. The younger part of the CVF consists of 4 chains 


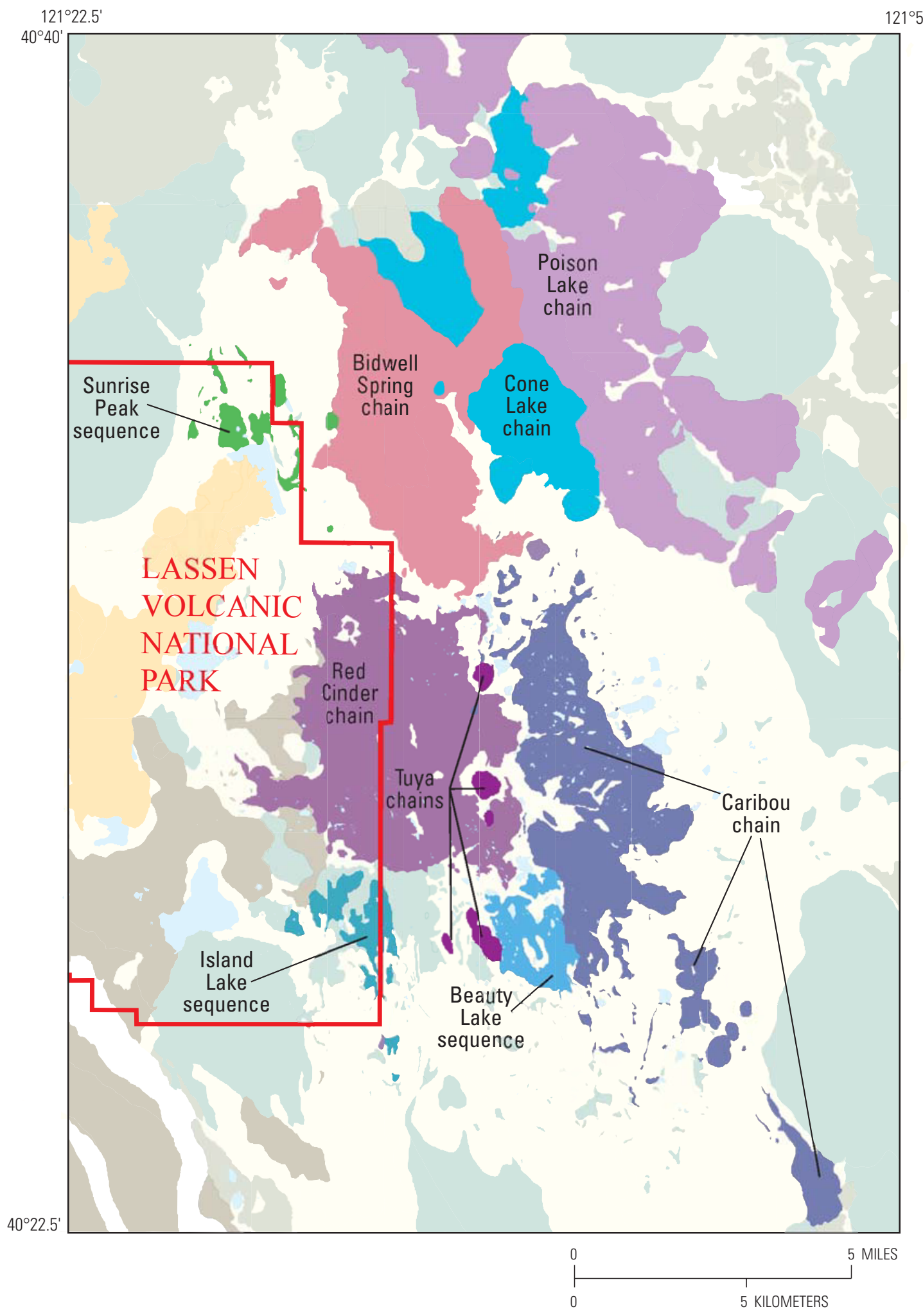

Figure 10. Generalized geologic map of eastern part of Lassen Volcanic National Park and adjacent areas, emphasizing the location and extent of volcanic sequences and chains in the Caribou Volcanic Field. Lighter colors are units not part of Caribou Volcanic Field (see fig. 7). Map adapted from figure 6 of Clynne and Muffler (2010). 
of volcanoes $<110 \mathrm{ka}$. Most prominent is the weakly glaciated Red Cinder chain ( $\sim 100$ to $\sim 25 \mathrm{ka}$ ), located on the border of LVNP and the Caribou Wilderness. To the northeast, the Poison Lake chain is unglaciated, and the constructional forms of its 39 young basalt and basaltic andesite scoria cones and lava flows (110-100 ka) are well preserved (Muffler and others, 2011). Margins of the flows of the Bidwell Spring chain (one date of $46.3 \pm 3.4 \mathrm{ka}$ ) are slightly overlapped by till, particularly on the west side, but most of the prominent scoria cones are unglaciated. The CVF also contains two chains of tuyas (flat-topped subglacial volcanic constructs); the older is either $130-120 \mathrm{ka}$ or $\sim 60 \mathrm{ka}$, and the younger is $35-17 \mathrm{ka}$.

\section{Glacial Geology}

Glaciation has highly modified most of the volcanic units of the Lassen Volcanic Center (including Lassen Peak) as well as the southern part of the CVF. Terminal moraine complexes are present in all the major drainages emanating from LVNP, and a considerable area is covered with ground moraine (Clynne and Muffler, 2010). Areas at lower elevation $(<5,200-6,000$ feet $)$ are generally unglaciated, and primary volcanic morphology is preserved. A few volcanic units at higher elevation, in particular Chaos Crags and Cinder Cone, are younger than the 35-12 ka glaciation and retain their original volcanic carapaces.

At least five episodes of Pleistocene glaciation are recognized in the Lassen area (Crandell, 1972; Kane, 1982; Colman and Pierce, 1992; Turrin and others, 1998; see Clynne and Muffler [2010] or Muffler and Clynne [2015] for a comparison of different workers' depictions of the glacial geology of the Lassen area). On most parts of the geologic map of Clynne and Muffler (2010), the glacial deposits are generalized into two major units: till of younger glaciations (35-12 ka), and till of older glaciations (60-70 ka and >130 ka). That usage is followed in this guidebook.

\section{Hydrothermal Features}

The Lassen geothermal system (fig. 11) consists of a central vapor-dominated reservoir underlain by a reservoir of hot water at a temperature of $240{ }^{\circ} \mathrm{C}$ (Muffler and others, 1982; Ingebritsen and Sorey, 1985; Clynne and others, 2003; Ingebritsen and others, 2016). Morgan Hot Spring and Growler Hot Spring (figs. 11A and 12) are located in the canyon of Mill Creek, 3,200 ft (975 m) below Bumpass Hell, at the contact between Brokeoff Volcano and the underlying Maidu Volcanic Center). These springs mark the lateral discharge of near-neutral, chloride-bearing hot water from the deep hot-water reservoir under Bumpass Hell. In contrast to the acid-sulfate alteration at Bumpass Hell, Morgan Hot Spring and Growler Hot Spring deposit silica sinter. Deep hot water also was encountered in a commercial geothermal well at Terminal Geyser, in an area subsequently incorporated into Lassen Volcanic National Park. This deep hot water may be from a separate geothermal upflow (Janik and McLaren, 2010) centered at either Devils Kitchen or Boiling Springs Lake in the southeast part of the park (figs. 11A and 12). Heat loss from the thermal areas of Bumpass Hell, Sulphur Works, Pilot Pinnacle, and Little Hot Springs Valley totals 56 megawatts (MW), whereas the heat loss from Devils Kitchen and Boiling Springs Lake totals 49 MW (Sorey and Ingebritsen, 1995).

\section{Volcano-Related Hazards}

Clynne and others (2012) comprehensively evaluated five classes of volcano-related hazards in the Lassen region: (1) regional mafic lava flows and ash, (2) silicic lava domes, flows, and pyroclastic flows, (3) lahars, (4) hydrothermal hazards, and (5) landside and rockfall hazards. Robinson and Clynne (2012) presented details and modeling of lahar hazards, and Nathenson and others (2012) analyzed eruption probabilities. The average recurrence interval for regional mafic volcanism is 1,550 years, whereas the average recurrence interval for the Lassen Volcanic Center is 7,150 years. Hydrothermal hazards and landslide hazards are ongoing, particularly in the erosional amphitheater in Brokeoff Volcano (figure 19 of Clynne and others, 2012). Lahar hazards are primarily in the drainages heading in the high-elevation terrain around Lassen Peak, in particular Lost Creek, Hat Creek, and Manzanita Creek (Robinson and Clynne, 2012; figure 10 and plate 1 of Clynne and others, 2012). 


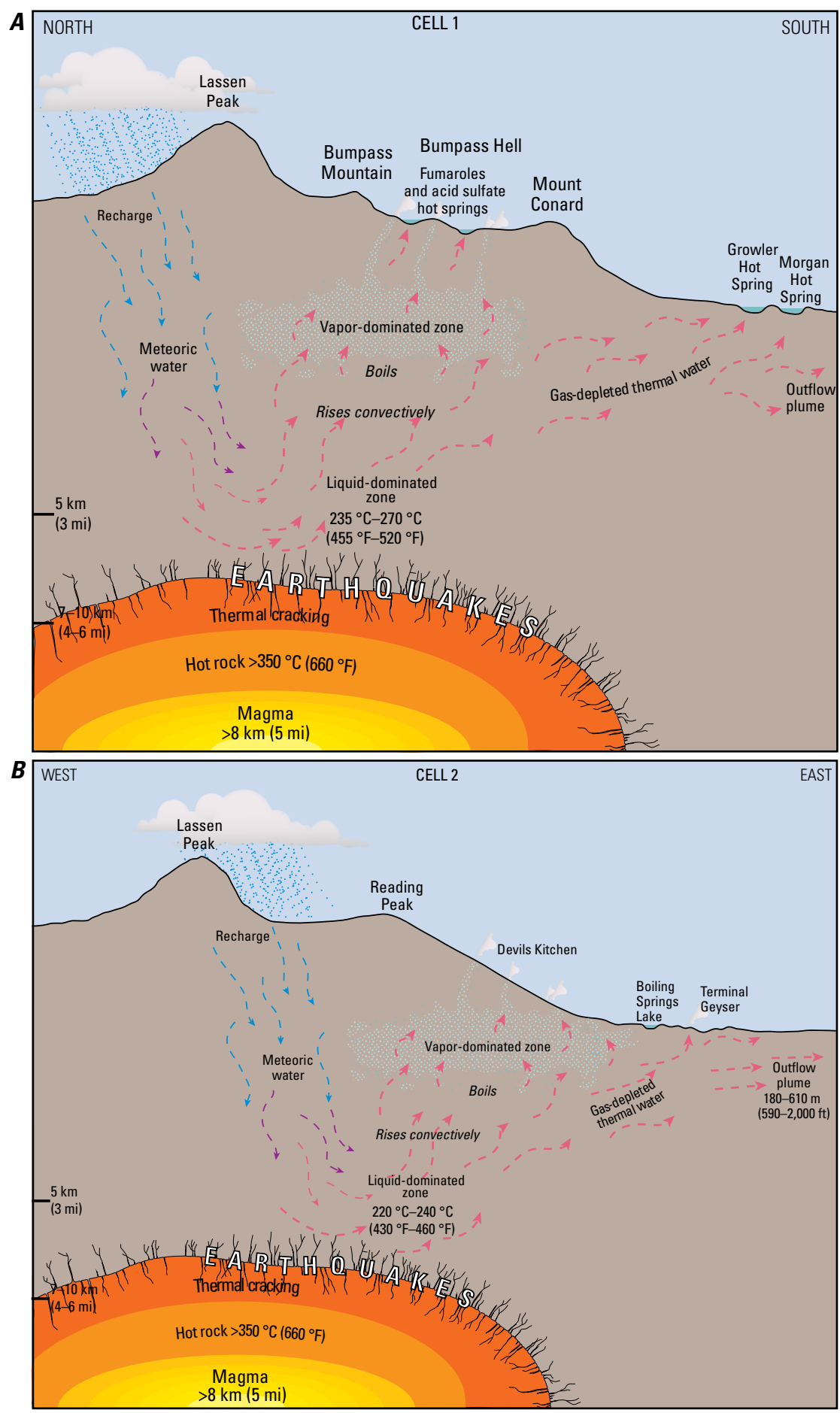

Figure 11. Diagrammatic cross sections of the Lassen hydrothermal system. The upper, northsouth cross section $(A)$ illustrates circulation in cell 1 of Janik and McLaren (2010), whereas the lower, east-west cross section $(B)$ illustrates circulation in their cell 2. In both cells, meteoric water percolates to depth and is heated by hot rock overlying a body or bodies of magma (shown generalized and diagrammatically). Hot water rises convectively and boils in response to decreasing pressure to form a vapor-dominated zone that releases steam and gases to surface fumaroles and acidic hot springs. The residual thermal water flows laterally and emerges as hot springs south of the park (cell 1) and was encountered in a now-abandoned geothermal well at Terminal Geyser (cell 2). Approximate depths indicated are below ground surface. Taken from figure 14 of KellerLynn (2014), in turn based on Janik and McLaren (2010), Clynne and others (2003), and Muffler and others (1982). 


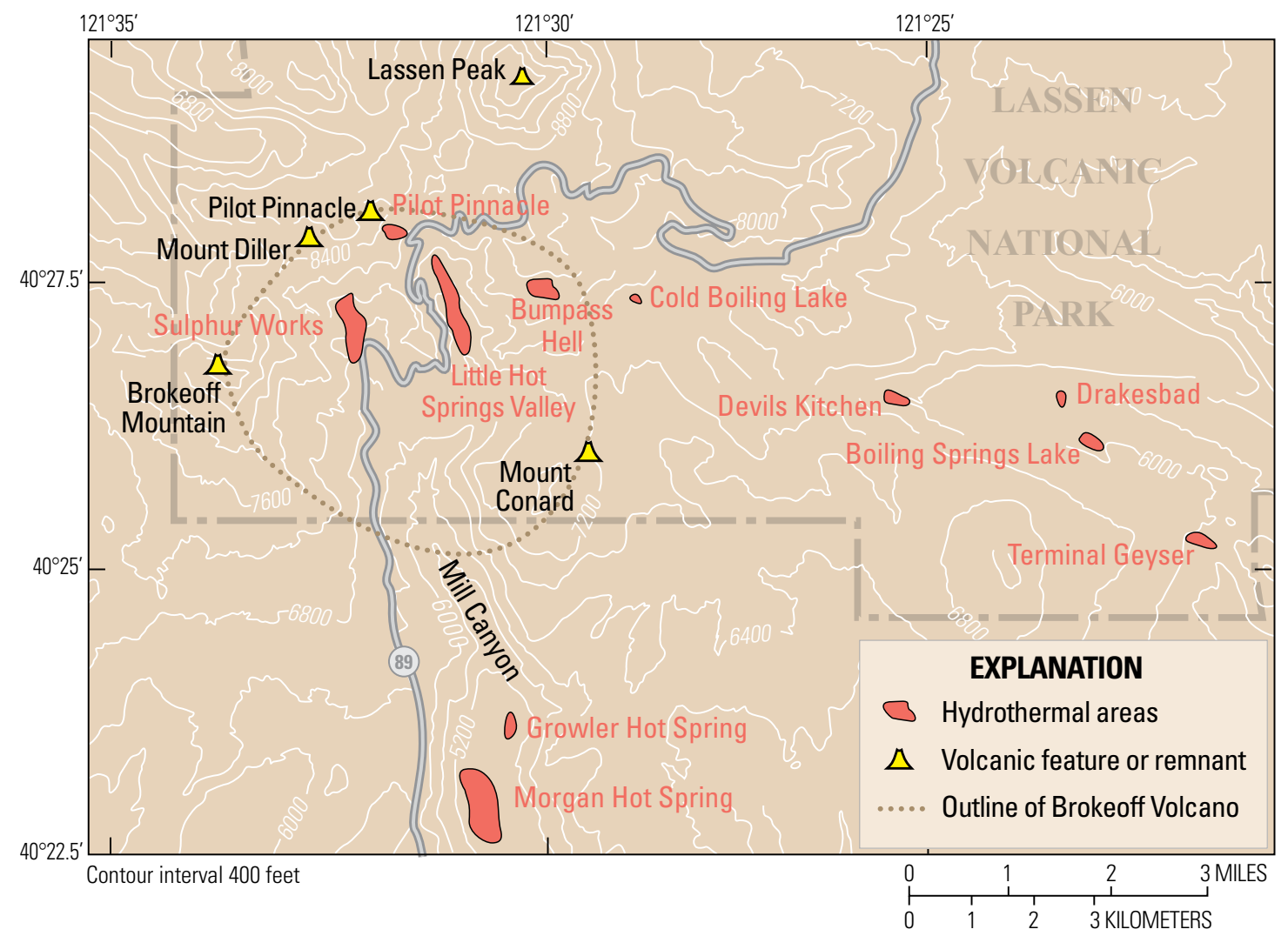

Figure 12. Map showing thermal areas in and adjacent to Lassen Volcanic National Park. From figure 8 of Clynne and others (2012).

\section{Road Log}

Reading the preceding "Geological Overview" section before launching into the road log will acquaint the user with the geologic framework and the stratigraphic terminology of the Lassen area, thus providing a context for specific discussions in the road log.

Numbers at left are distances in miles from starting point. Numbers in bold at the end of each entry are the distance in miles to the next entry. View directions are indicated by reference to a clock face - 12:00 means straight ahead, 9:00 means $90^{\circ}$ to left, 3:00 means $90^{\circ}$ to right.

Latitudes and longitudes are in datum WGS84/NAD83.

Potassium-Argon (K-Ar) and argon-argon $\left({ }^{40} \mathrm{Ar} /{ }^{39} \mathrm{Ar}\right)$ ages given in the text and figure captions of this guide can be found in Clynne and Muffler (2010) unless otherwise noted. All radiometric ages are calibrated to SB3 biotite.

\section{Day 1 (Pole Creek to Chester)}

This field trip begins where U.S. Forest Service (USFS) Road 49 (Medicine Lake Road; Powder Hill Road) intersects USFS Road 3 northeast of Bartle, and the day finishes at Chester.

0.0 Lat $41^{\circ} 19.38^{\prime} \mathrm{N}$., long $121^{\circ} 44.36^{\prime} \mathrm{W}$. Turn left (southeast and then east) on USFS 3 towards Slagger and Hambone. This region consists primarily of widespread, large low- potassium olivine tholeiites (LKOTs) that vented in the southern part of the Mount Shasta region and flowed south towards the Pit River. These basalts filled valleys between calc-alkaline edifices that are probably 2-3 million years old. The basalts are monotonously similar in appearance and cannot be distinguished one from another in the field, but they can be distinguished by their paleomagnetic directions and by subtle chemical differences. Their surface morphology has been completely obscured by weathering; flow surfaces are expressed as a deep red soil with occasional basalt boulders. The flows are well exposed only in prominent normal fault scarps, in rare roadcuts, and in a few canyon walls. Along USFS Road 3, these basalts consist of the tholeiitic basalt of Dead Horse Creek $(1,458 \pm 25 \mathrm{ka})$ and the tholeiitic basalt of Dry Lake $(262 \pm 18 \mathrm{ka}) ;{ }^{40} \mathrm{Ar} /{ }^{39} \mathrm{Ar}$ determinations by A.T. Calvert. The terrain is broken by many NNWSSE-trending normal faults. 0.9

Be sure to slow down at the warning signs at the old logging camp of Slagger. The stop markings on the road are at a crossroad ditch that you don't want to hit while going fast. 1.6

2.5 Old logging camp of Hambone. Continue east on USFS Road 3. 0.7 
3.2 Turn right (south) on USFS Road 24. The road is on the tholeiitic basalt of Roseburg Timber ( $795 \pm 9 \mathrm{ka}$; ${ }^{40} \mathrm{Ar}{ }^{\beta 9} \mathrm{Ar}$ determination by A.T. Calvert). 3.0

6.2 USFS Road 40N38 to left leads to Sand Flat Well. From here to the south the road is on the tholeiitic basalt of Pole Creek $\left(974 \pm 12 \mathrm{ka} ;{ }^{40} \mathrm{Ar}{ }^{\beta 9} \mathrm{Ar}\right.$ determination by A.T. Calvert). This basalt, whose vent is uncertain, flowed at least 20 miles south to its terminus on the north side of the Pit River (see Stop 1). $\mathbf{3 . 6}$

9.8 Lat $41^{\circ} 14.68^{\prime} \mathrm{N}$., long $121^{\circ} 41.24^{\prime} \mathrm{W}$. One of the few roadcuts in the tholeiitic basalt of Pole Creek. 4.1

13.9 T junction. Turn right (southwest). The old logging site of Pondosa is $1 \mathrm{mi}$ to the left. $\mathbf{0 . 3}$

14.2 Cross Bear Creek, one of the few streams in this area. $\mathbf{0 . 9}$

15.1 Turn left (southeast) onto Calif. Hwy 89. The highway is still on the upper surface of the tholeiitic basalt of Pole Creek. 1.5

16.6 Prominent electrical transmission line. 2.6

19.2 Junction on left with Shasta County Road A19 that leads southeast to Dana and McArthur. Continue straight on Calif. Hwy 89. 2.3

21.5 Brief view straight ahead of the Lassen region of the Cascades Volcanic Arc, dominated by $27 \pm 1$-ka Lassen Peak (10,457 ft; 3,187 m). To the right of Lassen Peak are $(210 \pm 120 \mathrm{ka})$ Magee Volcano $(8549 \mathrm{ft} ; 2606 \mathrm{~m})$ and $280 \pm 6$ ka Burney Mountain $(7863$ ft; 2397m) 4.6.

26.1 Clark Creek road (USFS route 37N05) to right (west); Cayton Valley road (Shasta County road 9P001) to left (east). Continue straight (south) on Calif. Hwy 89. To the left (east) are views across Cayton Valley to Soldier Mountain, an old (2-3 Ma) calc-alkaline edifice. 1.3

27.4 Road (USFS 37N03) to left (east) leads across the tholeiitic basalt of Pole Creek to Coyote Flat Reservoir and eventually to the summit of Soldier Mountain. 0.1

27.5 Stop 1. Pillows in tholeiitic basalt of Pole Creek. Lat $41^{\circ} 01.92^{\prime} \mathrm{N}$., long $121^{\circ} 37.69^{\prime} \mathrm{W}$. The second pulloff on right allows safe parking for several vehicles. Cross Calif. Hwy 89 very carefully to avoid high-speed vehicles, particularly trucks. Excellent roadcut exposes white diatomite overlain by the tholeiitic basalt of Pole Creek. At the base of the basalt are excellent pillows (fig. 13), showing that the basalt flowed into an ancestral lake that was depositing diatomite. The age of $974 \pm 12 \mathrm{ka}$ for the basalt provides an upper age constraint for the extensive diatomite in this area. Overlying the pillows is pillow breccia and then subaerial basalt at the top of the roadcut. A similar exposure in a wall of the Dicalite diatomite mine $2.7 \mathrm{mi}$ to the west also shows the tholeiitic basalt of Pole Creek overlying at least $500 \mathrm{ft}$ $(150 \mathrm{~m})$ of diatomite. Be very aware of fast-moving traffic when crossing back over Calif. Hwy 89. 1.2

28.7 Bridge over Lake Britton, a lake impounded behind a Pacific Gas and Electric (PG\&E) dam $2.8 \mathrm{mi}(4.5 \mathrm{~km})$ to the west. The lake is along the course of the Pit River, the major tributary of the Sacramento River. The highway bridge abutments and the railroad bridge over the highway are in diatomite, but outcrops just south of the bridge are older calc-alkaline volcanic rock. Drill holes show that the diatomite here was deposited in rugged canyon topography cut into older calc-alkaline volcanic rocks. The prominent abandoned railroad bridge to the east was featured in the 1986 movie "Stand by Me." 0.3

On the left just beyond the south abutment of the highway bridge is a bold outcrop of the older calcalkaline andesite, overlain by white diatomite in a prominent large roadcut. $\mathbf{0 . 2}$

29.2 After passing another large roadcut of white diatomite, the highway climbs up through the tholeiite basalt of Rocky Ledge (197 \pm 8 ka; weighted average of three ${ }^{40} \mathrm{Ar} /{ }^{39} \mathrm{Ar}$ determinations by A.T. Calvert) onto its upper surface. At the base of the basalt is a small, red littoral cone, probably formed at the distal terminus of the LKOT where it entered a lake. An exposure $1.1 \mathrm{mi}$ to the southeast displays excellent pillow breccia at the base of the flow.

The tholeiitic basalt of Rocky Ledge vented $>12 \mathrm{mi}$ $(19 \mathrm{~km})$ to the south and flowed north to the Pit River. Basalt flows both from the north and from the south terminate along the course of the modern Pit River, indicating that this area has been a topographic low for at least a million years. $\mathbf{1 . 2}$

30.4 Entrance on right to McArthur Burney Falls Memorial State Park. A short walk from the parking lot leads one to Burney Falls (fig. 14), which, during periods of high flow, cascades over the tholeiitic basalt of Rocky Ledge onto older calc-alkaline volcanic rocks. During periods of low flow, most of the water comes from joints within the flow and from the breccia at the base of the flow.

To the south of this point, Calif. Hwy 89 is on the flat, upper surface of the tholeiitic basalt of Rocky Ledge, one of four extensive tholeiitic basalts that flow north towards the Pit River (fig. 15). These basalts are monotonously similar in appearance and cannot be distinguished readily one from another in the field or petrographically. They are, however, 


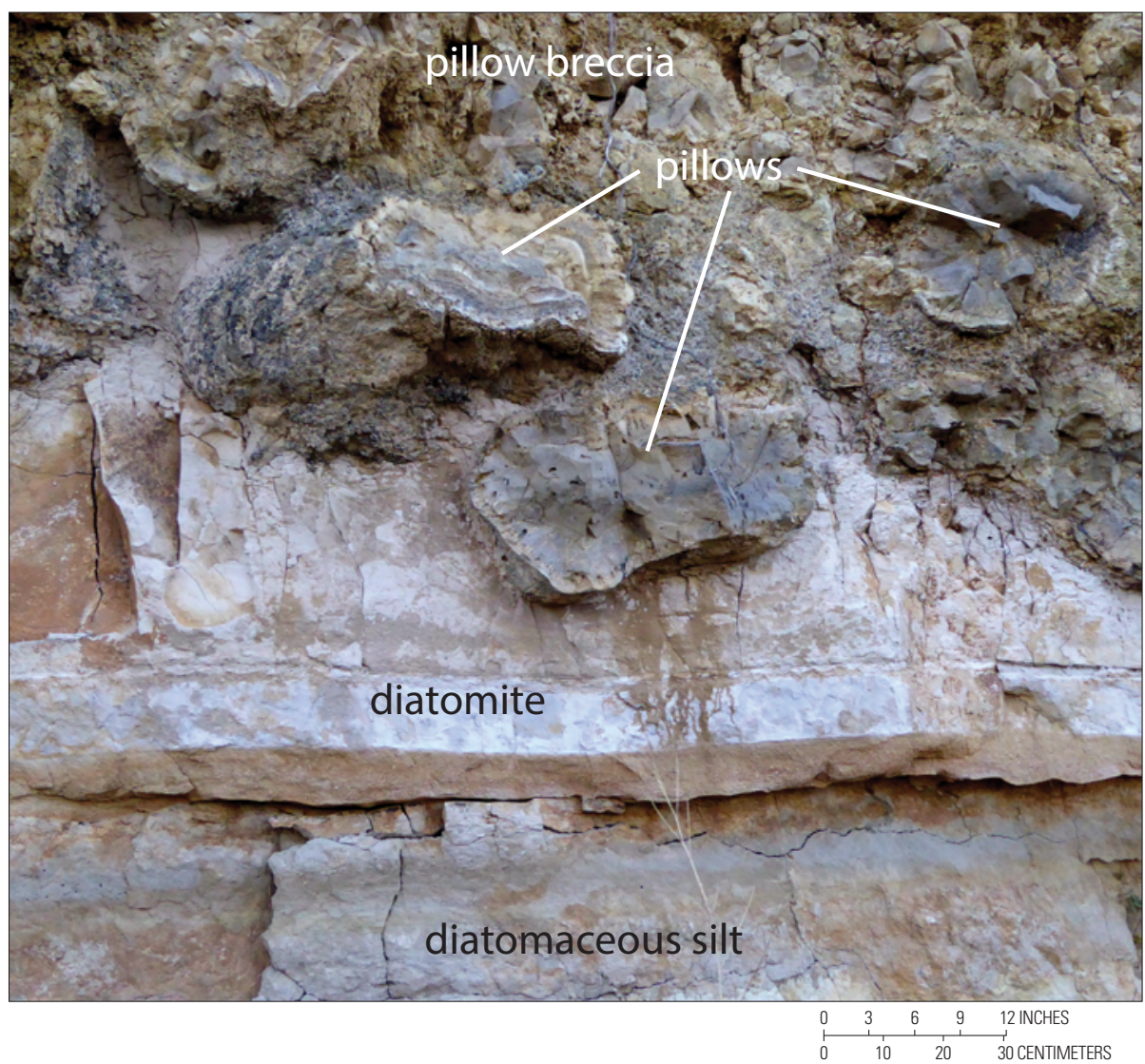

Figure 13. Photograph of pillows at the base of the tholeiitic basalt of Pole Creek.

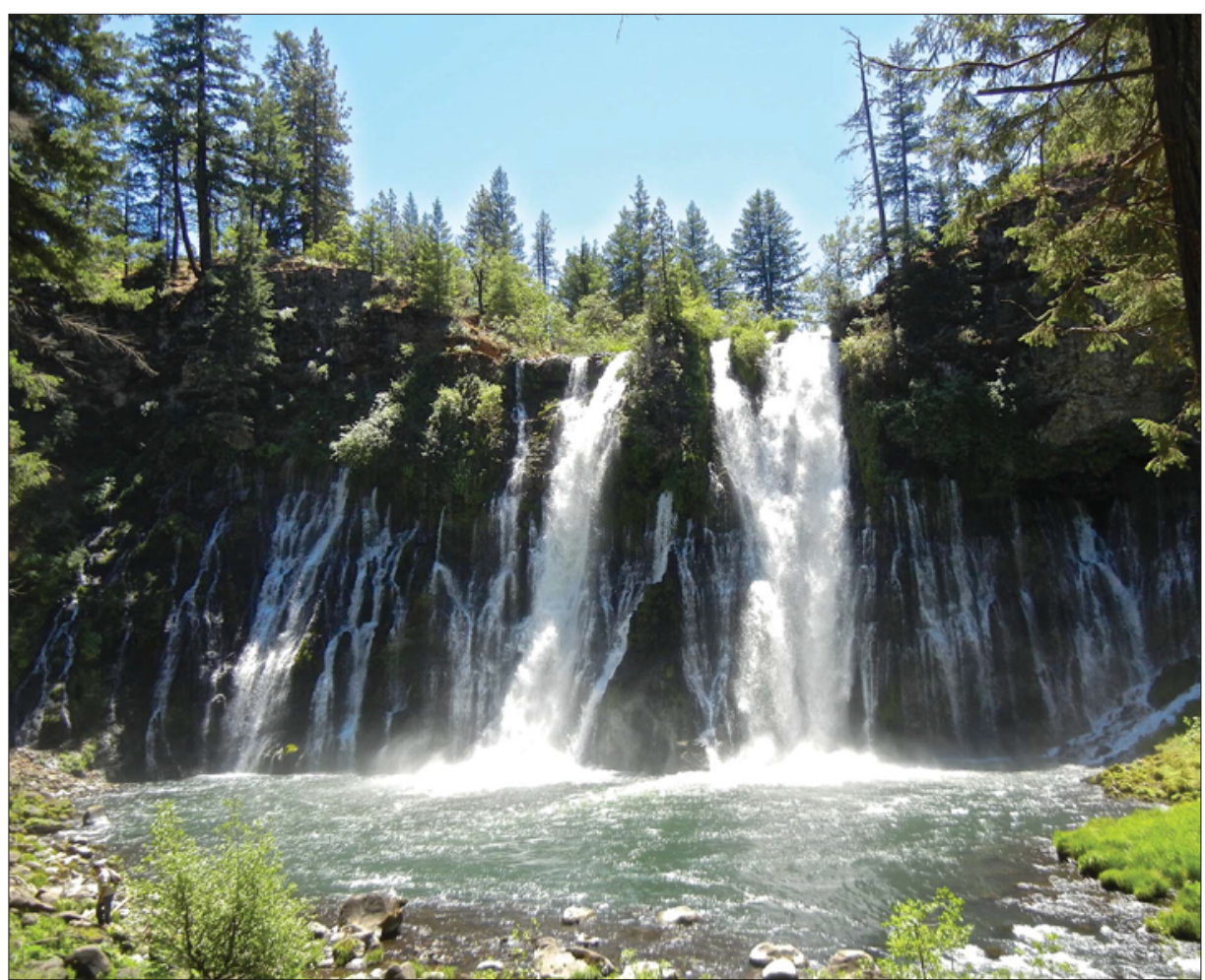

Figure 14. Photograph of Burney Falls. The contact between the tholeiitic basalt of Rocky Ledge and the underlying calc-alkaline volcanic rocks $(\sim 2.5 \mathrm{Ma})$ is marked by a line of springs emerging about one-third of the way down the falls. 


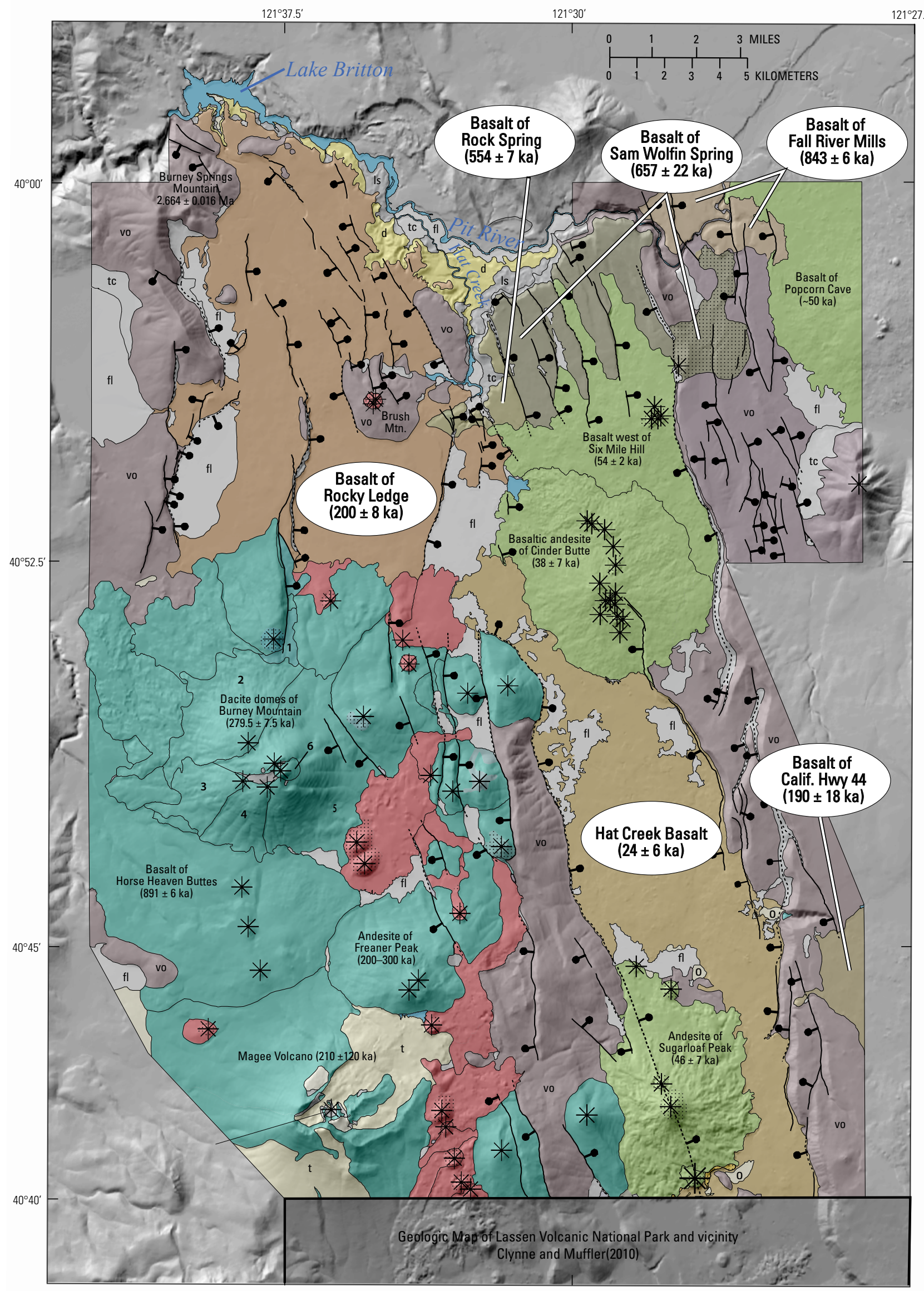


quite distinctive in age, paleomagnetic direction, and major-element composition (Muffler and others, 2012), allowing robust discrimination of the tholeiitic basalt of Rocky Ledge from the tholeiitic basalt of Rock Spring (545.7 $\pm 6.7 \mathrm{ka})$ and the tholeiitic basalt of Sam Wolfin Spring $(646 \pm 23 \mathrm{ka}) ;{ }^{40} \mathrm{Ar} /{ }^{39} \mathrm{Ar}$ determination by A.T. Calvert). These tholeiitic units are overlain to the east by the calc-alkaline basalt west of Sixmile Hill $\left(53.5 \pm 2.0 \mathrm{ka} ;{ }^{40} \mathrm{Ar} /{ }^{39} \mathrm{Ar}\right.$ determination by A.T. Calvert) and to the south by the tholeiitic Hat Creek Basalt (24 $\pm 6 \mathrm{ka})$ and the calc-alkaline basaltic andesite of Cinder Butte ( $38 \pm 7 \mathrm{ka}$, both ages from Turrin and others, 2007). The Hat Creek Basalt has also been dated at $23.8 \pm 1.4 \mathrm{ka}$ by ${ }^{3} \mathrm{He}$ surface-exposure dating (Rood and others, 2015).

The tholeiitic basalts in the northern part of the Hat Creek Valley inundated low topography between higher-elevation remnants of $>1$-Ma calc-alkaline volcanoes (fig. 15). Tholeiitic basalts have a wider areal extent than calc-alkaline edifices and thus serve as important regional stratigraphic markers. Their upper surfaces, having little relief, also provide strain markers useful for measuring fault offsets and estimating times between significant earthquakes. $\mathbf{0 . 9}$

31.3 To the right (west) is Burney Creek, often dry during the late summer. To the left across the grassy area is a prominent normal fault (up to the east) exposing several flow units of the tholeiitic basalt of Rocky Ledge. 1.1

32.4 To the right (west) is Clark Creek Road, which leads 3 mi northwest to the PG\&E Pit \#3 Dam, which impounds Lake Britton. Calif. Hwy 89 continues south on the flat upper surface of the tholeiitic basalt of Rocky Ledge. $\mathbf{1 . 5}$

33.9 Old railroad grade that provides excellent exposures of the tholeiitic basalt of Rocky Ledge. 1.4

35.3 Calif. Hwy 89 crosses right of way for a major PG\&E gas pipeline. 0.9

36.2 Four-way stop at a busy, major highway intersection. To the left, Calif. Hwy 299 leads northeast on the tholeiitic basalt of Rocky Ledge across the Pit River to Fall River Mills and eventually to Alturas. To the right, Calif. Hwy 299 leads southwest to the towns of Johnson Park and Burney and eventually to Redding. Continue straight across on Calif. Hwy 89 towards Old Station. The highway is on the flat upper surface of the tholeiitic basalt of Rocky Ledge. The mountain to the left, Brush Mountain, is a complex, faulted, calc-alkaline volcano probably $2.5 \mathrm{Ma}$ in age. Surprisingly, the summit of the mountain consists of a much younger basalt plug and basaltic andesite cinder cone, perhaps $\sim 50$ ka in age. 4.5

40.7 Highway 89 passes from the tholeiitic basalt of Rocky Ledge across a fault scarp onto alluvium. 0.1

40.8 Stop 2. View of the crest of the Cascades Volcanic Arc. Lat $40^{\circ} 52.81^{\prime}$ N., long $121^{\circ} 33.83^{\prime} \mathrm{W}$. Good pullout on the right with an excellent panoramic view (fig. 16).

Figure 15. Geologic map showing the distribution of the six tholeiitic basalt flows in the northern part of Hat Creek Valley.

\section{EXPLANATION}

$\mathrm{fl}$ Alluvial and lacustrine deposits

\begin{tabular}{|c|}
\hline Hat Creek Basalt \\
\hline Basalt of Calif. Hwy 44 \\
\hline Basalt of Rocky Ledge \\
\hline Basalt of Rock Spring \\
\hline Basalt of Sam Wolfin Spring \\
\hline Basalt of Fall River Mills \\
\hline
\end{tabular}

$\mathrm{t}$ of last major glaciation $(\sim 35-15 \mathrm{ka})$

Calc-alkaline edifices east of present axis of Cascades Arc ( $<50 \mathrm{ka})$ Lava flows of calc-alkaline basalt and basaltic andesite along present axis of Cascades Arc (<100 ka)

Prominent calc-alkaline volcanoes along Cascades axis (900-200 ka) Diatomite (bracketing dates 1.79 and $1.14 \mathrm{Ma}$ )

Older volcanic rocks (3-1 Ma); calc-alkaline and tholeiite
Low-potassium olivine tholeiite basalts (850-24 ka)

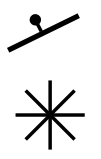

Normal fault (ball on downthrown side; dotted where concealed)

Volcanic vent

Cinders and tuff 


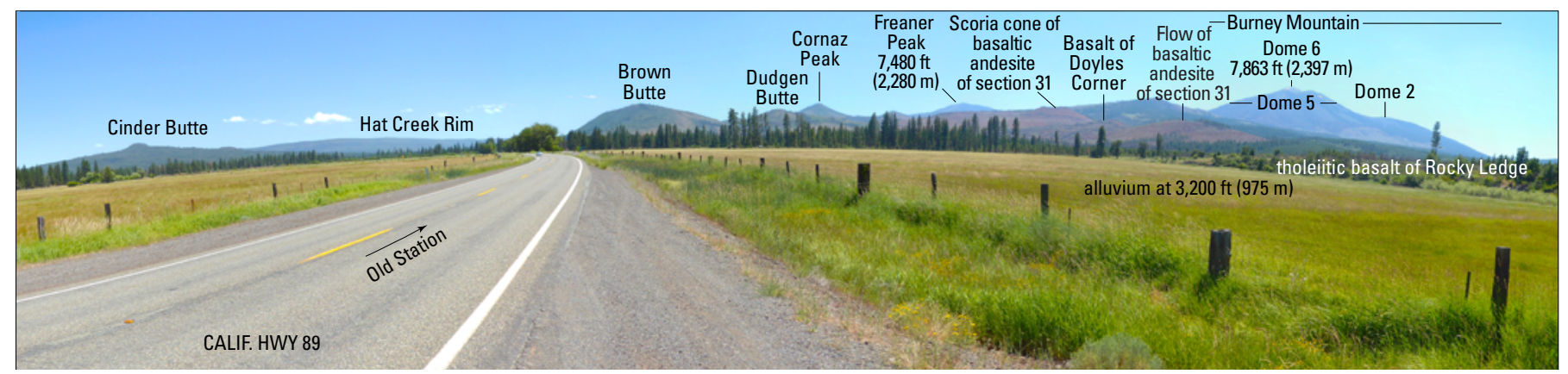

Figure 16. Panoramic photograph looking south at the Cascades Volcanic Arc and Hat Creek Valley. The four photographs combined in this panorama were taken from Stop 2 (mile 40.5; lat 4052.81' N., long 121 $33.83^{\prime}$ W.) on Calif. Hwy 89, 4.7 miles south of the intersection of Calif. Hwy 89 with Calif. Hwy 299. At the far right is a fault scarp exposing the tholeiitic basalt of Rocky Ledge. Prominent peaks along the Cascades Volcanic Arc are the dacite dome complex of Burney Mountain and the dacite of Freaner Peak. Only domes 2, 5 and 6 of Burney Mountain are visible from this vantage point; domes 3 and 4 are on the far side of the mountain, and dome $1\left(280 \pm 6 \mathrm{ka} ;{ }^{40} \mathrm{Ar} /{ }^{39} \mathrm{Ar}\right.$ determination by M.A. Lanphere) is below the skyline on the extreme right of the panorama. To the east of Burney Mountain and Freaner Peak are the basalt of Doyles Corner and the underlying basaltic andesite of section 31, both units probably $<50$ ka. Cornaz Peak, Dudgen Butte, and Brown Butte are much older ( 2 Ma?) calc-alkaline edifices east of the Cascades axis; Brown Butte is broken on the east (left) by a normal fault bounding the west side of the Hat Creek Valley, which is bounded on the east by the Hat Creek Rim (see Stop 3 and figs. 19 and 20). The basaltic andesite of Cinder Butte ( $38 \pm 7 \mathrm{ka}$ ) sits within the northern part of the Hat Creek Valley.

For the next 17 miles, Calif. Hwy 89 lies primarily on the Hat Creek Basalt, at $24 \pm 6$ ka the youngest volcanic rock in the north-trending Hat Creek Valley (figs. 15 and 17). This LKOT lava erupted from a km-long spatter rampart located just south of Old Station and flowed to the north in lava tubes for nearly 20 miles $(32 \mathrm{~km})$. The flow covered $\sim 100 \mathrm{~km}^{2}$, is as much as $30 \mathrm{~m}$ thick in the Hat Creek Valley, and has a volume of $\sim 2.5 \mathrm{~km}^{3} . \mathbf{0 . 2}$

41.0 Doyles Corner. Cassel Road (Shasta County Road 7R01) to the left (east) leads back to the north along Hat Creek to the town of Cassel. Rising River, a large tributary of Hat Creek at the northern toe of the Hat Creek Basalt, is 2.5 miles northeast of Doyles Corner. Rising River is fed primarily by water flowing from beneath and within the Hat Creek Basalt. Excellent view to the left of Cinder Butte. 0.8

41.8 Highway crosses Hat Creek and passes along the contact between alluvium to the left (east) and the toe of the late Pleistocene basalt of Doyles Corner to the right (west). This basalt is one of the units in the belt of the young lava flows that lies west of the early to middle Pleistocene(?) andesites that form the west rim of the Hat Creek Valley. The vent for the basalt of Doyles Corner is 2 miles to the southwest. $\mathbf{1 . 6}$

43.4 Highway crosses Hat Creek. Highway is on the Hat Creek Basalt, but steep hills just to the right (west) of the highway are much older (early to middle Pleistocene?) andesites. $\mathbf{1 . 7}$
45.1 Turn left onto Doty Road Loop (Shasta County Road 6R200) and continue across the Hat Creek Basalt. Good views to right (west) of the older Pleistocene calcalkaline rocks. 0.2

\subsection{Cross Hat Creek. 0.7}

46.0 Turn left on Bidwell Road (Shasta County 6R201) and continue east across the Hat Creek Basalt. To the right (south) are excellent views of the Hat Creek Rim, Prospect Peak, West Prospect Peak, Sugarloaf Peak, and Wilcox Peak (fig. 18). 1.8

47.8 Road to right (south) leads to the Hat Creek Radio Observatory. $\mathbf{0 . 5}$

48.3 At T-junction, turn left. $\mathbf{0 . 3}$

48.6 Stop 3: "Active Scarp" of the Hat Creek Fault. Lat $40^{\circ} 49.84^{\prime}$ N., long $121^{\circ} 27.64^{\prime}$ W. See fig. 19 for location, fig. 20 for photographic view.

According to Blakeslee and Kattenhorn (2013) and Kattenhorn and others (2016), the Hat Creek Fault is composed of three subparallel systems of scarps of different ages that accrued a cumulative throw in excess of $600 \mathrm{~m}$ (see also Muffler and others, 1994, and Walker, 2008). The oldest and largest system of scarps, referred to as the "Rim," has as much as $350 \mathrm{~m}$ of throw and defines the easternmost extent of the fault system. A lava flow at the top of the footwall has a K-Ar age of $924 \pm 24 \mathrm{ka}$ (Clynne and Muffler, 2010), thus constraining the maximum age of the fault system. The fault scarps 


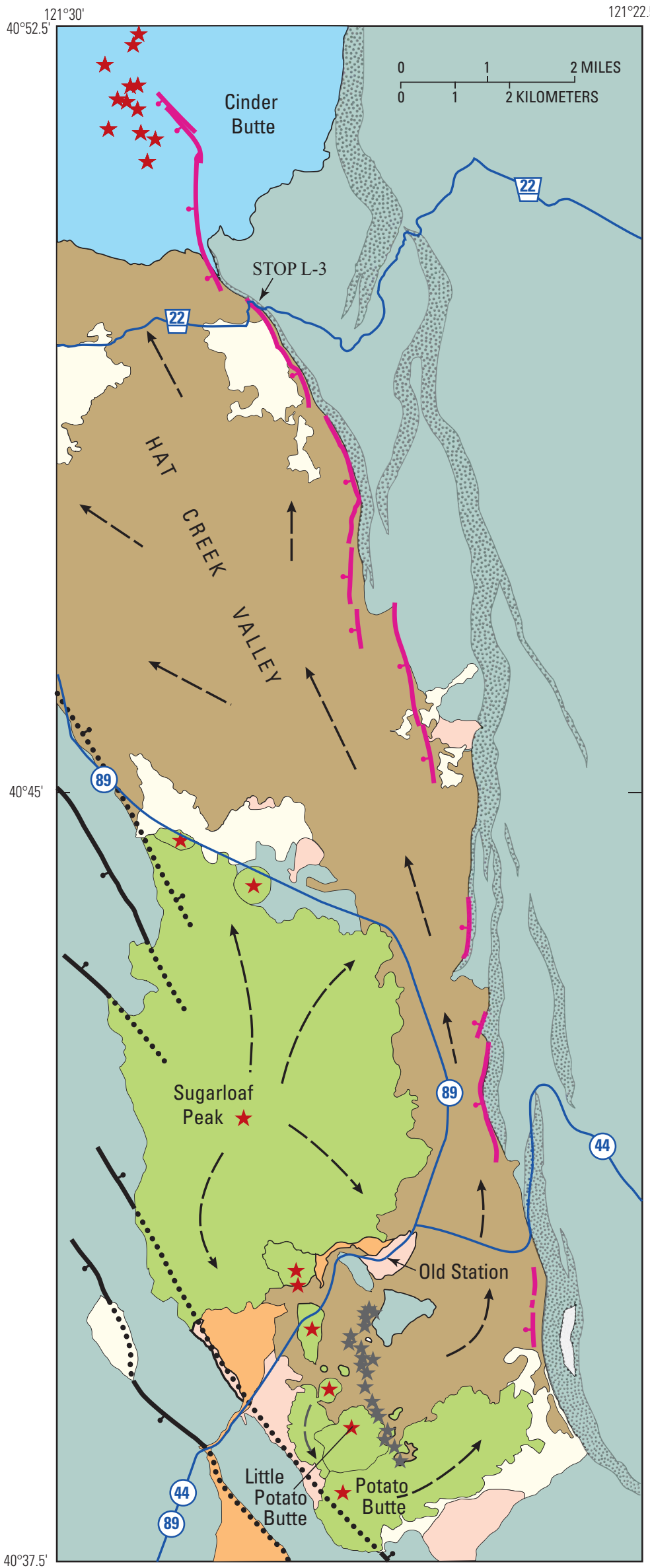

\begin{tabular}{|c|c|}
\hline & EXPLANATION \\
\hline & $\begin{array}{l}\text { Retreated } \sim 35^{\circ} \text { west-dipping } \\
\text { scarps of Hat Creek fault system }\end{array}$ \\
\hline & $\begin{array}{l}\text { Young fault scarps cutting } \\
\text { Hat Creek Basalt and basaltic } \\
\text { andesite of Cinder Butte }\end{array}$ \\
\hline & $\begin{array}{l}\text { Fault scarps marking west } \\
\text { side of Hat Creek Valley } \\
\text { (dotted where concealed) }\end{array}$ \\
\hline$\star$ & Tholeiitic vent \\
\hline$\star$ & Calc-alkaline vent \\
\hline 1 & Flow direction \\
\hline & $\begin{array}{l}\text { Flowage deposits from } 1915 \text { Lassen } \\
\text { Peak and } 1,103 \pm 13 \text { B.P. Chaos Crags } \\
\text { eruptions }\end{array}$ \\
\hline & Alluvium (Holocene) \\
\hline & $\begin{array}{l}\text { Outwash gravels related to } \\
\text { recession of last major glaciation } \\
(\sim 15 \mathrm{ka})\end{array}$ \\
\hline & Hat Creek Basalt (24 \pm 6 ka) \\
\hline & $\begin{array}{l}\text { Basaltic andesite of Cinder Butte } \\
(38 \pm 7 \mathrm{ka})\end{array}$ \\
\hline & 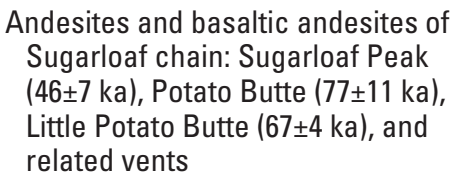 \\
\hline & $\begin{array}{l}\text { Older volcanic rocks (mostly early } \\
\text { Pleistocene) }\end{array}$ \\
\hline 89 & California State highway \\
\hline 22 & National Forest road \\
\hline
\end{tabular}

Figure 17. Generalized geologic map of the northward-flowing Hat Creek Basalt. Adapted from Turrin and others (2007). The concealed fault on the west margin of Hat Creek Valley north of the Sugarloaf Peak edifice is a retreated fault scarp, down to the east, with the 24-ka Hat Creek Basalt lapping against the fault scarp and concealing it. This fault appears to be roughly equivalent in age to the "Rim" and "Pali" scarps of Blakeslee and Kattenhorn (2013), equivalent to the "Rim" and "Intermediate" scarps of Kattenhorn and others (2016). To the south, however, old fault scarps on the west side of Hat Creek Valley are completely obscured by the 77-46 ka andesites and basaltic andesites of the Sugarloaf chain. The west side of Hat Creek Valley displays no evidence of young faulting equivalent to the "Active Scarp" of Blakeslee and Kattenhorn (2013), equivalent to the "Recent scarp" of Kattenhorn and others (2016); see Stop 3. 


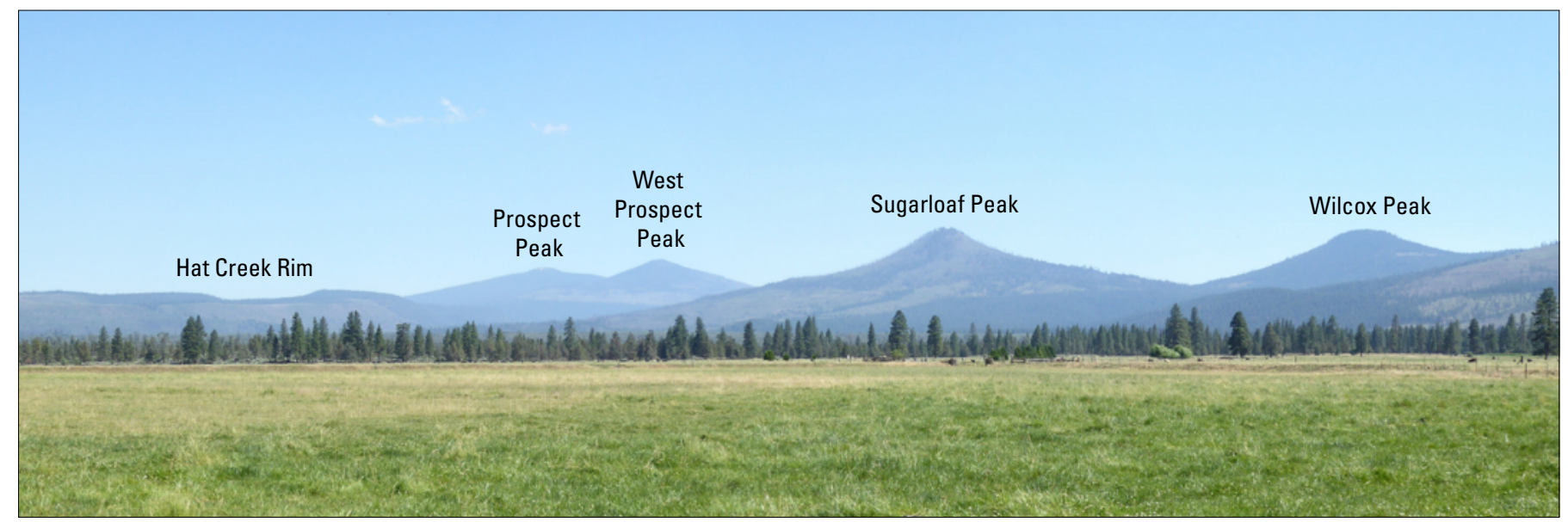

Figure 18. Panoramic photograph looking south from Bidwell Road towards the Cascades Volcanic Arc. From left to right, the prominent calc-alkaline volcanoes are Prospect Peak (247 \pm 56 ka), West Prospect Peak (400-300 ka), Sugarloaf Peak (46 $\pm 7 \mathrm{ka})$, and Wilcox Peak $(500-700 \mathrm{ka})$. At the far left, older volcanic rocks are uplifted along Hat Creek Fault. The grassy area in the foreground is alluvium overlying the Hat Creek Basalt (24 $\pm 6 \mathrm{ka})$.

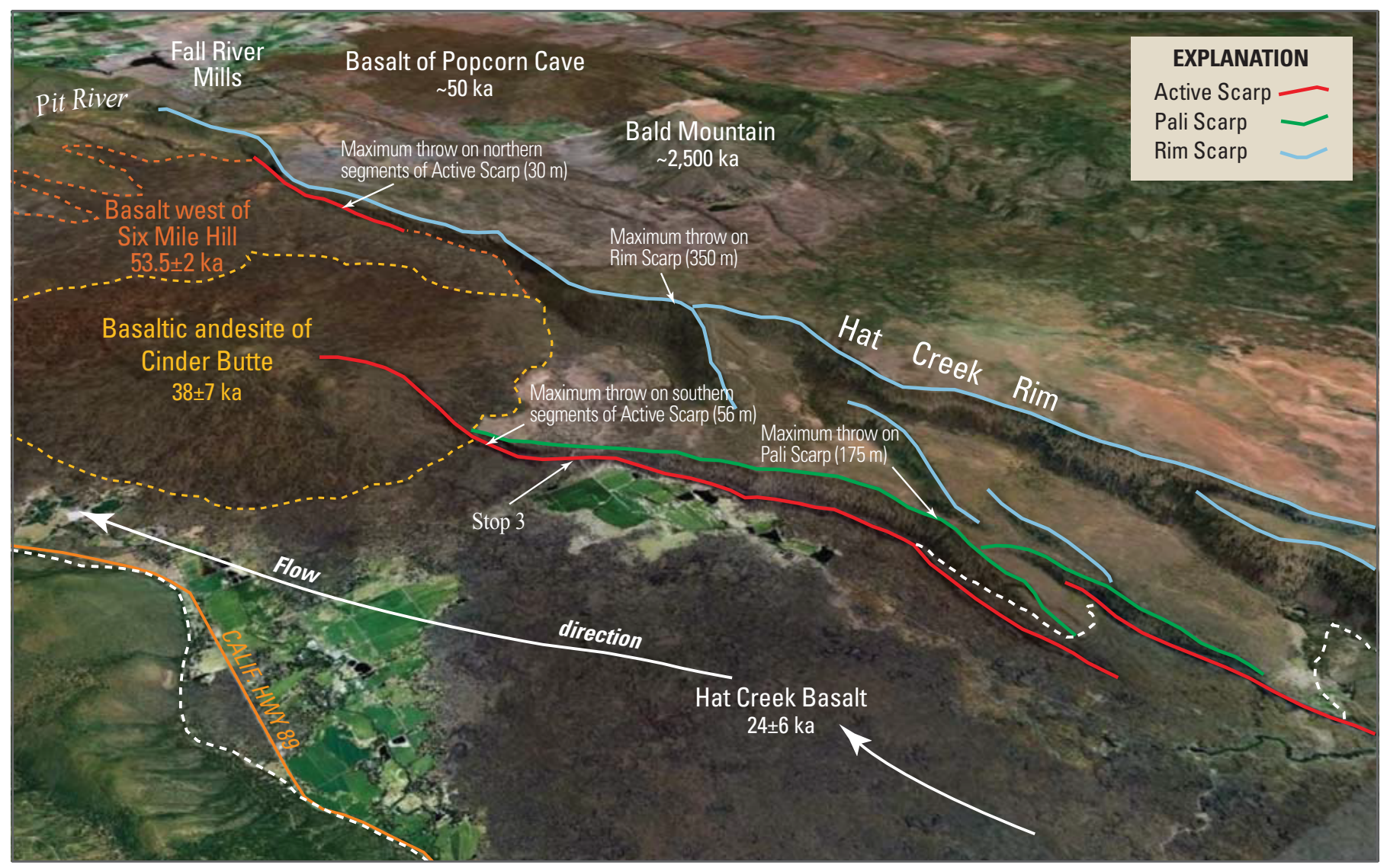

Figure 19. Oblique satellite image with perspective view down and to the northeast of the northern part of the Hat Creek Fault. The "Active Scarp" of Blakeslee and Kattenhorn (2013) (youngest) is shown in red, the "Pali" scarp (intermediate) in green, and the "Rim" scarp (oldest) in blue; fault lines are drawn at the top of the scarps. Dashed orange line is the margin of the basalt west of Sixmile Hill, dashed yellow line is the margin of the basaltic andesite of Cinder Butte, and dashed white line is the margin of the Hat Creek Basalt. Figure is adapted from figure 5 of Blakeslee and Kattenhorn (2013). The "Active Scarp" and "Pali Scarp" of Blakeslee and Kattenhorn are equivalent, respectively, to the "Recent scarp" and "Intermediate scarp" of Kattenhorn and others (2016). 


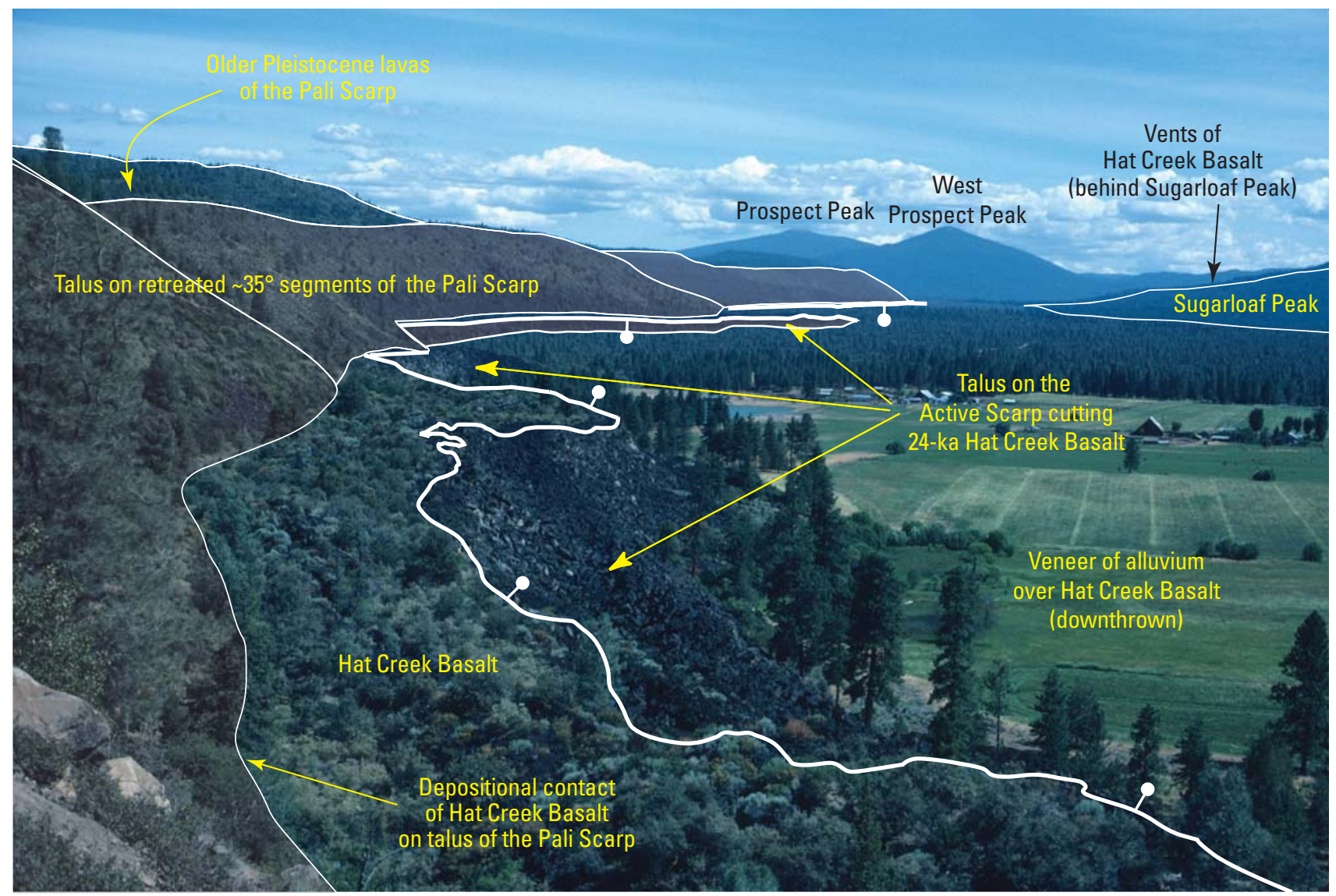

Figure 20. Annotated photograph from Stop 3 looking south along the "Active Scarp" (of Blakeslee and Kattenhorn, 2013) of the Hat Creek Fault. The "Active Scarp" of Blakeslee and Kattenhorn (2013) is equivalent to the "Recent scarp" of Kattenhorn and others (2016).

of intermediate age west of the Rim Scarp, referred to by Blakeslee and Kattenhorn (2013) as the "Pali" and by Kattenhorn and others (2016) as the "Intermediate" scarp, have accrued as much as $\sim 175 \mathrm{~m}$ of throw (Walker, 2008). The youngest system of scarp segments, referred to by Blakeslee and Kattenhorn (2013) as the "Active Scarp" and by Kattenhorn and others (2016) as the "Recent scarp," has a maximum throw of $56 \mathrm{~m}$ and exhibits evidence of repeated earthquake activity since the late Pleistocene.

$5.5 \mathrm{mi}(8.9 \mathrm{~km})$ to the south, near the mouth of the canyon of Lost Creek, the Hat Creek Basalt is overlain by 15-ka gravel deposits that are related to the end of the last major glaciation. These gravels are displaced $\sim 20 \mathrm{~m}$ across the youngest scarp of the Hat Creek Fault (Muffler and others, 1994). Despite this conspicuous evidence of young faulting, modern seismicity in this area is low and diffuse (LaForge and Hawkins, 1986; Waldhauser and Schaff, 2008; see also figure 3 of Blakeslee and Kattenhorn, 2013). The Hat Creek Fault has produced no large historical earthquakes (Blakeslee and Kattenhorn, 2013). Walker and Kattenhorn (2008) and Blakeslee and Kattenhorn (2013) estimated that the fault has the potential to produce an earthquake of moment magnitude of 6.7 and has a recurrence interval of $667 \pm 167 \mathrm{yr}$. Rood and others (2015), however, have used cosmogenic ${ }^{3} \mathrm{He}$ surface exposure dating of scarp surfaces and the surfaces of blocks that were exposed by toppling to define a sequence of seven earthquake events on the "Active" (youngest) scarp. The slip for each event is $\sim 4 \mathrm{~m}$, implying earthquakes of magnitude $6.9-7$ with an average recurrence interval of $1.7 \pm 0.6 \mathrm{ka}$.

The "Active" (or "Recent") scarp of the Hat Creek Fault is not just a simple disruption of the Hat Creek Basalt along a vertical fault. A succinct summary of the near-surface fault features is presented by Blakeslee and Kattenhorn (2013, p. 1402; see also their figure 6):

The Active Scarp is also characterized by a hanging wall fault-trace monocline (Fig. 6B), representing the near-surface flexing of the Hat Creek Basalt above an upward-propagating fault tip prior to initial surface breaching by the fault. . . Along the Active Scarp, the monocline accounts for as much as $33 \mathrm{~m}$ of throw (Walker, 2008), implying numerous fault slip events prior to breaching 
of the surface along the upper hinge line of the fold. Once the surface was breached by the fault, monocline growth ceased, and all subsequent surface throw accumulation was directed along the vertical scarp.

Progressive disaggregation of the monocline occurred along the Active Scarp in response to the local effects of repeated fault rupture, with the final stage of monocline history being its complete collapse, rendering the monocline to a pile of rubble ... commonly composed of intact columns of basalt ...

Comprehensive descriptions of the various surface features of the "Active Scarp" of Blakeslee and Kattenhorn (2013) are presented by Walker (2008), along with detailed maps of the fault traces, prepared by Marie Jackson, for several parts of the fault trace.

Modeling of gravity and magnetic highs along the eastern margin of the Hat Creek Valley suggests that the Hat Creek Fault dips $75^{\circ}-85^{\circ}$ in the upper crust (Langenheim and others, 2016). The spatial relationship of the fault as modeled by the potential-field data, the geometry of the youngest strand of the fault, and relocated seismicity (Waldhauser and Schaff, 2008) suggest that deformation continues to step westward across the valley, consistent with a small component of right-lateral slip in an extensional environment.

The 29-mile-long Hat Creek Fault is contiguous with faults to the south in the eastern part of Lassen Volcanic National Park that also join with faults bounding the Lake Almanor Graben, a total distance of more than 50 miles. Together these structures define the westernmost major graben of the Basin and Range Province. The Basin and Range structural regime is expanding to the west and impinging upon the Cascades Volcanic Arc in the Lassen area. Older faults (for example, the Butte Creek Rim) occur farther to the east.

The prominent volcanic edifices across the Hat Creek Valley comprise the crest of the Cascade Range.

Turn around and retrace route to mile 46.0, the intersection of Bidwell and Doty Loop Roads. 2.4

51.0 Excellent view at 12:00 of Burney Mountain emphasizing the youngest dome at the summit. $\mathbf{0 . 2}$

51.2 Turn left (south) back onto Doty Road Loop (Shasta County Road 6R200), still on the Hat Creek Basalt. 0.4

\subsection{Cross Hat Creek. 0.9}

52.5 Turn left (south) onto Calif. Hwy 89, still on the Hat Creek Basalt.
The ridge to the right (west) of the highway consists of older andesitic rocks and separates the Hat Creek Basalt from a north-trending belt (fig. 15, units shown in red) of quite young basalts and basaltic andesites, as yet undated. $\mathbf{4 . 0}$

56.5 Wilcox Road on the left (east). In the distance to the east, the prominent canyon of Lost Creek cuts through the Hat Creek Rim. The water in Lost Creek is derived by underground flow from Butte Creek (east of the Hat Creek Rim) and ultimately from the eastern part of Lassen Volcanic National Park. An intracanyon calcalkaline basaltic andesite flow has been dated at $332.3 \pm 7.5 \mathrm{ka}$, whereas the flows high on the canyon walls have dates of $1,899.5 \pm 25.2 \mathrm{ka}$ and $1,516.5 \pm 23.5 \mathrm{ka}$ $\left({ }^{40} \mathrm{Ar} /{ }^{\beta 9} \mathrm{Ar}\right.$ determinations by Andrew T. Calvert). 0.5

57.0 The highway leaves the Hat Creek Basalt and crosses a small patch of alluvium. Rocks to the right (southwest) of the road for the next 1.1 miles are calc-alkaline andesites and basaltic andesites of the Sugarloaf chain. The small cones adjacent to the road are the andesite of hill 4041 and the andesite of Calif. Hwy 89, whereas the large volcano to the south is the andesite of Sugarloaf Peak (46 \pm 7 ka). 0.8

Rancheria RV Park on the right. $\mathbf{0 . 8}$

58.6 Highway passes onto an outlier of the older andesitic rocks that form the west rim of the Hat Creek Valley. 1.1

59.7 At the bridge across Hat Creek, Calif. Hwy 89 passes from the older andesitic rocks back onto the Hat Creek Basalt. 0.6

60.3 Ahead and to the right are excellent views of the rugged flows of Sugarloaf Peak ( $46 \pm 7 \mathrm{ka}$ ), made prominent by a recent devastating forest fire. To the left (east) are excellent views of the Hat Creek Rim. Directly ahead are West Prospect Peak and (to the left) Prospect Peak. 1.9

62.2 Excellent view straight ahead of Lassen Peak and (to the right) Chaos Crags. 1.1

63.3 Turnoff to left leads to Subway Cave, a U.S. Forest Service exhibit that allows exploration of part of a lava tube in the Hat Creek Basalt. 0.3

63.6 Junction of Calif. Hwys 89 and 44. Turn left on Calif. Hwy 44. Note that no services are available on Hwy 44 until the city of Susanville (51 miles). $\mathbf{1 . 4}$

65.0 Cross the Hat Creek Fault and climb up the eroded 1,000-foot-high (350-m-high) fault scarp of the Hat Creek Rim. 
Rocks exposed on the eroded fault scarp of the Hat Creek Rim are regional basalts and andesites similar to the volcanic rocks on the west side of Hat Creek Valley. Two rocks from the top of the fault scarp gave ages of $1,645 \pm 35 \mathrm{ka}$ and $924 \pm 24 \mathrm{ka}$ (Clynne and Muffler, 2010). Total vertical offset has been at least $300 \mathrm{~m}$ (1,000 ft) in the past million years. The valley bottom has been filled with younger basalt flows, so the observed offset is a minimum amount. $\mathbf{1 . 4}$

66.4 Turn left onto side road to Hat Creek Rim Overlook. 0.4

66.8 Stop 4: Hat Creek Rim Overlook. Lat $40^{\circ} 42.12^{\prime}$ N., long $121^{\circ} 24.36^{\prime} \mathrm{W}$. From this vantage point at the top of the Hat Creek Fault scarp, one gets an excellent view of the crest of the Cascade Range from the Lassen Volcanic Center to Mount Shasta. To the south, in the Lassen Volcanic Center, prominent visible features include Lassen Peak, Chaos Crags, and Raker Peak, which is a $270 \pm 18$ ka hybrid andesite of the Twin Lakes sequence. Regional volcanoes include Table Mountain ( 700 ka) and Badger Mountain, a faulted $708 \pm 21 \mathrm{ka}$ andesite shield.

Volcanoes of the Cascade Range north of Lassen Peak are identified in an annotated panorama of the Cascade Range (fig. 21) taken from Parhams Point, 1.85 miles south-southeast (see Stop G-1 of Muffler and Clynne, 2015). These volcanoes are typical of Cascade Range volcanoes outside volcanic centers or away from large volcanoes. The flat, brush-covered area in the foreground and valley floor is the $24 \pm 6 \mathrm{ka}$ tholeiitic Hat Creek Basalt (Turrin and others, 2007), and the low mound just to the south of Old Station is its vent area. West of the vent area of the Hat Creek Basalt is the north-south-trending Sugarloaf chain of sparsely porphyritic olivine and pyroxene basaltic andesite and andesite volcanoes (all calc-alkaline), consisting of Sugarloaf Peak (46 $\pm 7 \mathrm{ka})$, Little Potato Butte (67 $\pm 4 \mathrm{ka})$, Potato Butte $(77 \pm 11 \mathrm{ka})$, and several smaller vents (Turrin and others, 2007). Together the Potato Buttes, the Hat Creek Basalt, and Sugarloaf Peak obscure the western boundary fault of the Hat Creek Valley that can be seen as a scarp farther north.
In the distance, to the left of Sugarloaf Peak, the cones in the Red Lake Mountain group ( $\sim 50 \mathrm{ka})$ and the southern end of the Tumble Buttes chain (Bear Wallow Butte; $35.1 \pm 3.1 \mathrm{ka}$ ) can be discerned. Hidden behind Sugarloaf Peak is deeply glaciated Magee volcano (Borg, 1989), the upper part of which has a K-Ar date of $210 \pm 120 \mathrm{ka}$. Older volcanoes and flows in this area are cut by many small faults. The prominent cone-shaped mountain to the north is Burney Mountain, a complex of 6 lava domes; the oldest dome has a ${ }^{40} \mathrm{Ar} /{ }^{39} \mathrm{Ar}$ age of $280 \pm 6 \mathrm{ka}$ (M.A. Lanphere, written commun., 1998). The area east of Burney Mountain contains a number of young scoria cones and lava flows, some of which may be postglacial.

On a clear day, Mount Shasta can be seen in the distance. With a volume of $>400 \mathrm{~km}^{3}$, it is the largest composite volcano in the high Cascade Range (Calvert and Christiansen, 2011). Its elevation is 14,179 feet (4,322 m), nearly 4,000 feet (1,130 m) higher than Lassen Peak. At $>300$ ka, Mount Shasta experienced an enormous debris avalanche that nearly destroyed the ancestral Sand Flat volcano (Crandell and others, 1984; Crandell, 1989), which is dated at $\sim 700-400 \mathrm{ka}$ (Calvert and Christiansen, 2011). The present edifice comprises four overlapping cones (Christiansen and Miller, 1989; Calvert and Christiansen, 2011): Sargents Ridge ( 300-100 ka), Misery Hill (60-35 ka), Shastina ( $\sim 11 \mathrm{ka})$, and Hotlum (11 $-3.1 \mathrm{ka})$. The last activity of Mount Shasta may have been a very small eruption in 1786 C.E. (Finch, 1930). Although that specific eruption is questionable, there is evidence of mildly explosive activity at Mount Shasta during the past few millennia, but probably no magmatic eruptions since $3.1 \mathrm{ka}$ (R.L. Christiansen and A.T. Calvert, oral commun., 2016).

Return to Calif. Hwy 44. 0.4

67.2 Turn left onto Calif. Hwy 44 and proceed north and then east towards Susanville. 1.6

68.8 On right is U.S. Forest Service Road 33N56. An excellent view of the Cascade Range (fig. 21) can be obtained by detouring $1.3 \mathrm{mi}$ south on this unpaved road (see Stop G-1 of Muffler and Clynne, 2015). 1.5

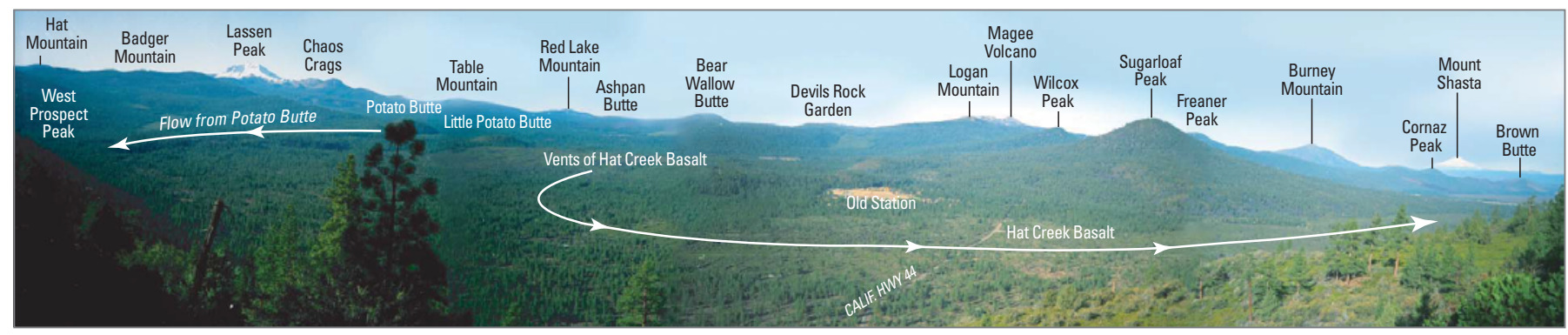

Figure 21. Panoramic photograph looking southwest (left) to northwest (right) from Parhams Point across the Hat Creek Graben and the Hat Creek Basalt ( $24 \pm 6$ ka) towards the crest of the Cascade Range north of Lassen Volcanic National Park. 
70.3 Summit Lake on the left is in a small fault-bounded depression. $\mathbf{1 . 0}$

71.3 Roadcut in basaltic andesite of Signal Butte $(\sim 1,000$ $900 \mathrm{ka})$, which erupted from the large scoria cone $0.7 \mathrm{mi}$ at 1:30. This lava flow is cut by small faults oriented parallel to the Hat Creek Fault and can be considered as the youngest unit of the Hat Creek Rim. 0.7

72.0 Contact with the tholeiitic basalt of Calif. Hwy 44 $(190 \pm 18 \mathrm{ka})$, exposed in good road cuts just ahead. This thin lava flow of sparsely porphyritic olivine basalt (49.6 percent $\mathrm{SiO}_{2}$ ) erupted from a fissure at hill 5855, $1.75 \mathrm{mi}$ to the south-southwest. This extensive lava flow was fed by lava tubes and flowed north along the base of Butte Creek Rim for $>9 \mathrm{mi}$ $(15 \mathrm{~km})$. It also flowed to the west and barely spilled over the Hat Creek Rim. The surface of the flow is relatively flat and has low relief, although punctuated by widely spaced tumuli. $\mathrm{A}^{40} \mathrm{Ar} /{ }^{39} \mathrm{Ar}$ age of $190 \pm 18 \mathrm{ka}$ is consistent with the flow's excursional magnetic direction (D.E. Champion, written commun., 2006). 1.0

73.0 Lassen County line. $\mathbf{1 . 6}$

74.6 View back to the right (southwest) of West Prospect

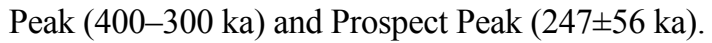
These andesite and basaltic andesite shield volcanoes are typical of regional calc-alkaline edifices.

At 2:00 is Sunrise Peak, the highly glaciated vent for the basalts of Sunrise Peak (393 $\pm 4 \mathrm{ka}$ ), at the western edge of the Caribou Volcanic Field just east of Butte Lake.

In the distance at 9:30 is the shield volcano of Blacks Mountain, a nearly aphyric olivine andesite (K-Ar date 2,403 \pm 19 ka; G.B. Dalrymple, written commun., 1991). This unusual regional calc-alkaline rock has a silica content of 59 percent $\mathrm{SiO}_{2}$ but contains only a few tiny olivine phenocrysts.

Highway in this area passes over glacial outwash brought from the volcanic highlands to the south along Butte Creek. 0.8

75.4 At right is U.S. Forest Service Road 32N21, a washboard unpaved road that goes $\sim 6$ miles south into LVNP. From the end of the road at Butte Lake (lat $40^{\circ} 33.90^{\prime} \mathrm{N}$., long $121^{\circ} 18.17^{\prime} \mathrm{W}$.; detailed description at Stop G-3 of Muffler and Clynne, 2015) is a 1.8 -mile $(2.9-\mathrm{km})$ trail that goes to the top of Cinder Cone, which, at 1666 C.E., is the youngest mafic volcano in the Lassen region (Sheppard and others, 2009). The products of the Cinder Cone eruption consist of five lava flows, two nested scoria cones, and a widespread mafic ash-fall deposit
(Clynne and others, 2000a; Clynne and others, 2002). Cinder Cone is part of the younger Twin Lakes sequence of the Lassen domefield. A scramble from Butte Lake up the west flank of Sunrise Peak east of Butte Lake to a bluff at approximately lat $40^{\circ} 33.35^{\prime} \mathrm{N}$., $40^{\circ} 33.35^{\prime} \mathrm{N}$., long $121^{\circ} 16.85^{\prime} \mathrm{N}$., long $121^{\circ} 16.85^{\prime} \mathrm{W}$. is rewarded by a spectacular view of Cinder Cone, Lassen Peak, and Chaos Crags (fig. 22). 1.6

$77.0 \quad$ U.S. Forest Service Road 32N26 goes south towards the young Bidwell Spring chain of the Caribou Volcanic Field. 0.6

77.6 View at 12:00 of scoria cones of the Poison Lake chain, a line of 39 small, monogenetic calc-alkaline basaltic volcanoes in a zone $14 \mathrm{~km}$ long and $2 \mathrm{~km}$ wide trending north-northwest parallel to and partially burying nearby Quaternary normal faults. 1.9

79.5 Stop 5: Poison Lake chain. Lat $40^{\circ} 39.21^{\prime}$ N., long $121^{\circ} 12.49^{\prime} \mathrm{W}$. Pull off on right shoulder. Be very aware of fast-moving traffic. On the left is Poison Lake. Visible from this point are several prominent scoria and agglutinate cones that mark vents for volcanoes of the Poison Lake chain, part of the Caribou Volcanic Field. The northern half of the Caribou Volcanic Field, including the Poison Lake chain, has not been glaciated, and constructional forms are well preserved. The 39 units of the Poison Lake chain (fig. 23) fall into 9 distinct groups based on stratigraphy, petrography, and major-element geochemistry (Muffler and others, 2011). Many units contain only sparse olivine; a few units are distinctly porphyritic with olivine, clinopyroxene, and plagioclase. $\mathrm{MgO}-\mathrm{SiO}_{2}, \mathrm{~K}_{2} \mathrm{O}-\mathrm{SiO}_{2}$, and $\mathrm{TiO}_{2}-\mathrm{SiO}_{2}$ relations illustrate clear differences in compatible and incompatible elements among the groups. Limited trace-element and ${ }^{87} \mathrm{Sr} /{ }^{86} \mathrm{Sr}$ data suggest little, if any, interaction with the upper crust. Precise ${ }^{40} \mathrm{Ar} /{ }^{39} \mathrm{Ar}$ determinations show that the lavas of the Poison Lake chain erupted at 110-100 ka. Paleomagnetic remanent directions suggest that the entire Poison Lake chain could represent three short-lived episodes of volcanism within a period as brief as 500 years. Collectively, the data indicate that each of the nine groups represents a small, discrete magma batch generated in the mantle and stored briefly in the lower crust. Episodic movement along a north-northwest normal fault zone provided transitory conduits for these batches of magma to ascend to the surface and erupt as distinct volcanic groups, each aligned along a segment of the Poison Lake chain.

Across Poison Lake at 2:00 is Cal Mountain, a regional calc-alkaline shield volcano of olivine andesite $(2,345 \pm 49 \mathrm{ka})$. In the distance at 9:00 is Blacks Mountain (See fig. 1 for location). $\mathbf{2 . 3}$ 


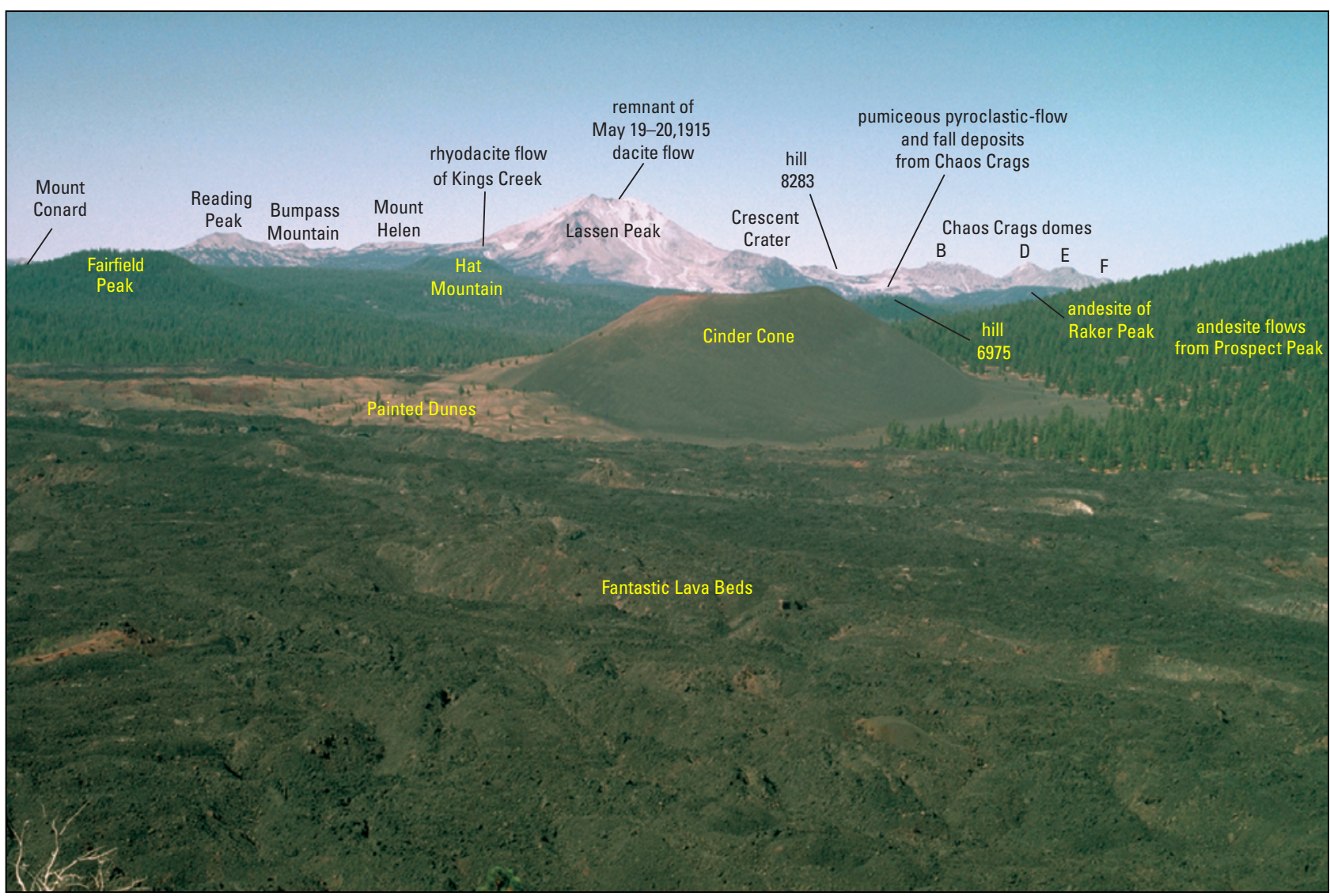

Figure 22. Photograph looking west-southwest from Sunrise Peak (just east of Butte Lake) towards the Lassen domefield (the youngest part of the Lassen Volcanic Center). In the foreground are Cinder Cone (1666 C.E.) and its related flows (Painted Dunes and Fantastic Lava Beds). Cinder Cone, Fairfield Peak (82 $\pm 14 \mathrm{ka})$, and Hat Mountain $(\sim 50-40 \mathrm{ka})$ are units in the younger Twin Lakes sequence of the Lassen domefield. Hill 6975 is the vent for the andesite and basaltic andesite of Cluster Lakes (300-250 ka). Both it and the andesite of Raker Peak ( $270 \pm 18 \mathrm{ka})$ are units in the older Twin Lakes sequence. Lassen Peak $(27 \pm 1 \mathrm{ka})$ and Chaos Crags $(1,103 \pm 13$ years B.P.) are domes of the Eagle Peak sequence of the Lassen domefield. Reading Peak (212 \pm 5 ka), Bumpass Mountain $(232 \pm 8 \mathrm{ka})$, Mount Helen $(249 \pm 12 \mathrm{ka})$, Crescent Crater $(236 \pm 1 \mathrm{ka})$, and hill $8283(261 \pm 5 \mathrm{ka})$ are domes of the Bumpass sequence. At the far left, Mount Conard is an erosional remnant of Brokeoff Volcano (590-385 ka), an older part of the Lassen Volcanic Center. Flows from Prospect Peak (247 $\pm 56 \mathrm{ka}$ ) are not part of the Lassen Volcanic Center, but instead are part of the regional calc-alkaline suite.

81.8 Pittville Road on left. For the next 8 miles, Calif. Hwy 44 traverses a flat valley underlain by the tholeiitic basalt of Grays Valley, a thin, extensive sheet of nearly aphyric, tholeiitic, olivine basalt ( 48.5 percent $\mathrm{SiO}_{2}$ ) erupted at $\sim 600$ ka from a spatter rampart east of Bogard Buttes (at 1:00). Multiple flow units of tube-fed pāhoehoe flowed north and filled the valley between Bogard Buttes, Cal Mountain, Cone Mountain (at 9:00), and Crater Mountain (at 11:00), all members of the regional calc-alkaline suite.

To the left (north of the highway) are the tracks of the Burlington Northern Santa Fe (BNSF) Railroad, originally the Western Pacific Railroad. From here to mile 107.3 just north of Westwood, this railroad parallels the field-trip route to the east. $\mathbf{1 . 4}$

83.2 To the right (south) of Calif. Hwy 44, a grove of aspen marks Robbers Spring, at the toe of a flow of the basalts of Robbers Spring (101.5 $\pm 8.7 \mathrm{ka}$ ), part of the Poison Lake chain (Muffler and others, 2011). 2.1

85.3 Mountains to the right of Calif. Hwy 44 are underlain by the dacite of Bogard Buttes (2,350 \pm 70 to 2,225 $\pm 49 \mathrm{ka}) . \mathbf{1 . 7}$

87.0 Inconspicuous vents for the tholeiitic basalt of Grays Valley are in the woods to the right. $\mathbf{0 . 7}$

87.7 Stop 6: Calc-alkaline volcanoes and intervening LKOT basalts. Lat $40^{\circ} 35.14^{\prime} \mathrm{N}$., long $121^{\circ} 05.29^{\prime} \mathrm{W}$. Pull off just beyond U.S. Forest Service Road 32N09.

The topography of this area is typical of that located to the east of the active Cascades Arc (see Borg, 1995). East of the Poison Lake chain, most of the volcanoes are 2-3 million years old, although a few are younger. 


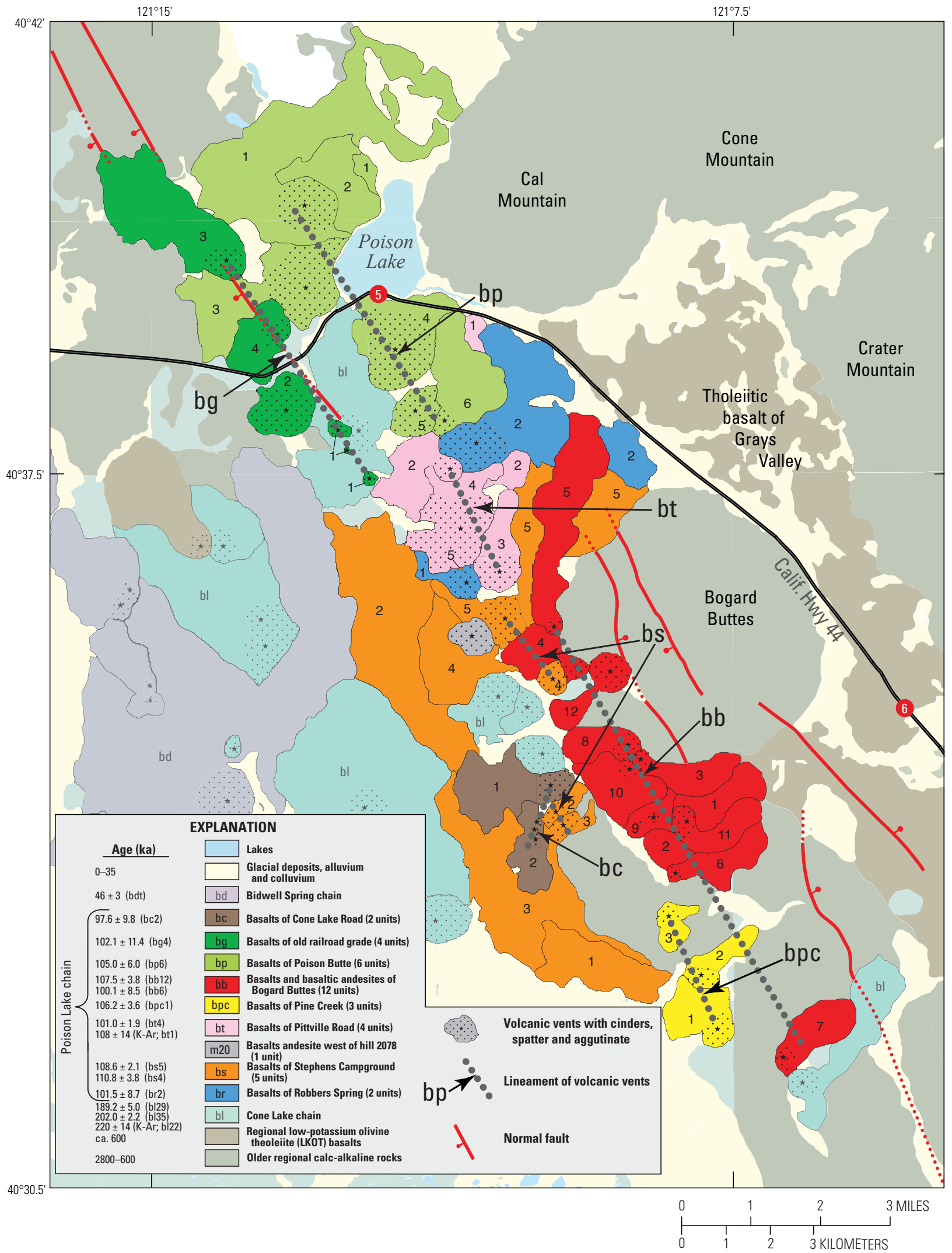

Figure 23. Geologic map of the Poison Lake chain, adapted from figure 4 of Muffler and others (2011). Unit labels (for example, bs = basalts of Stephens Campground) are taken from Clynne and Muffler (2010) as are abbreviations for rock type (for example, $\mathrm{b}=$ basalt; $\mathrm{m}=$ basaltic andesite) and group name (for example, $\mathrm{s}=$ Stephens Campground). Small numbers inside thin black lines denote individual mapped units within a group. Individual mapped units within the Bidwell Spring and Cone Lake chains are discriminated by thin black lines but are not labeled. Numbered red circles represent stop locations. 
The landscape is dotted with shield volcanoes, and the intervening valleys are flooded with widespread sheets of LKOT basalt lava. From this vantage point a number of shield volcanoes can be seen, including Crater Mountain, Bogard Buttes, Campbell Mountain, Logan Mountain, and Antelope Mountain. The shield volcanoes are composed of basaltic andesite to andesite lavas that are generally porphyritic, but without large or complexly zoned crystals. Each edifice is different; most are composed of a single rock type, but some have a narrow range of compositions. The density of faults on each volcano gives a relative indication of its age.

The large shield volcano to the northeast is Crater Mountain. Its surface is covered by forested block lava flows of augite-hypersthene andesite, with abundant small phenocrysts. A second, slightly more mafic olivine andesite lies mostly buried by the main edifice. The volcano is relatively large, with a nearly 5-mile diameter, rises about $1,750 \mathrm{ft}(530 \mathrm{~m})$ above the valley, and has a volume of about $10 \mathrm{~km}^{3}$. Crater Mountain is little eroded, has a thin soil, and is unfaulted. Its summit is weakly glaciated but still has a partially preserved scoria cone. It has a normal paleomagnetic direction and an age of $374 \pm 25 \mathrm{ka}$ (Germa and others, 2015). The lake at the summit is probably a cirque dammed by glacial deposits. U.S. Forest Service Road $32 \mathrm{~N} 08$, which leaves the highway at this point, is a well-maintained gravel road and makes a nice side trip to the summit of Crater Mountain.

Bogard Buttes, the forested shield volcano to the northwest, is composed of a single type of porphyritic augite-hypersthene dacite. It has a basal diameter of about $3 \mathrm{mi}$, rises $1,900 \mathrm{ft}(580 \mathrm{~m})$ above the valley floor, and has a volume of about $4 \mathrm{~km}^{3}$. The edifice has a thick soil, is cut by several conspicuous faults (not visible from this vantage point) and has no preserved vent area or scoria. Two K-Ar ages for Bogard Buttes are 2,350 \pm 70 and 2,225 $\pm 49 \mathrm{ka}$ (Clynne and Muffler, 2010).

$0.1 \mathrm{mi}$ south on USFS Road 32N09 and then $0.2 \mathrm{mi}$ west is Bogard Rest Area, constructed on the proximal high ground of the tholeiitic basalt of Grays Valley. This flow vented from the area of the inconspicuous low hills 0.25- 0.5 mile west of the rest area and flowed northward between Crater Mountain and Bogard Buttes into Grays Valley. The tholeiitic basalt of Grays Valley is a nearly aphyric, diktytaxitic, olivine basalt. The valley floor to the east of the rest area is flooded with another tholeiitic basalt lava flow, the basalt of Pine Creek Valley, which vented from an inconspicuous hill just above the fault scarp about 2 miles south-southeast of the rest area. The tholeiitic basalt of Pine Creek Valley is also a nearly aphyric, diktytaxitic, olivine basalt, but the two flows have subtle chemical differences. Neither of these basalt flows is dated, but both have normal polarity, thin soils, are relatively uneroded, and probably about $600 \mathrm{ka}$ in age.
This part of Calif. Hwy 44 marks the routes of both the Lassen Trail and the Nobles Trail to California from Missouri (Strong, 1989). The Lassen Trail was first traversed in 1847 by a party led by Peter Lassen. Coming from Goose Lake north of Alturas, the trail led down the Pit River and then south to what is now Calif. Hwy 44. The trail then went southeast and south, roughly paralleling the field-trip route, to Westwood and Big Meadows (now Lake Almanor) and thence down the ridge between Mill Creek and Deer Creek to the Sacramento Valley. The Nobles Trail, charted in 1851 by William Nobles, came west from Susanville along this section of Calif. Hwy 44, went south between Cinder Cone and Prospect Peak, crossed into the Hat Creek drainage, and then went down Shingletown Ridge to the Sacramento Valley. Along the parts of these trails near Calif. Hwy 44, emigrants to California in the early 1850s going southeast on the Lassen Trail were passing emigrants on the Nobles Trail travelling in the opposite, northwest direction! 1.0

88.7 Calif. Hwy 44 crosses over a nearly imperceptible contact between the tholeiitic basalt of Grays Valley and the tholeiitic basalt of Pine Creek Valley. Vents for this LKOT are in the hills to the south at 1:30. 0.7

To the right is U.S. Forest Service Road 31N26 leading west to Bogard Campground. The prominent scoria cone 2 miles away at 1:30 is the vent for the calc-alkaline basalt of Round Valley Butte ( $477 \pm 25 \mathrm{ka}$; K-Ar determination by G.B. Dalrymple). This basalt is separated from the tholeiitic basalt of Grays Valley by a series of discontinuous, en echelon normal faults (up to the southwest) that cut both units. 2.1

91.5 Roadcuts in the tholeiitic basalt of Pine Creek Valley. 0.7

92.2 Turn right onto Lassen County Road A21 south towards Westwood. [If one is not following the field trip guide to Westwood, he or she can continue east on Calif. Hwy 44 another 17.5 miles to a junction with Calif. Hwy 36 . From there, Calif. Hwy 36 continues another 6 miles east to the town of Susanville, where food, lodging, and gas services are available. A 1:100,000-scale geologic map of the Susanville Quadrangle (Grose and others, 2013) shows the geology along the route.] 0.2

92.4 Road curves right up the fault scarp onto the basalt of Round Valley Butte. 2.6

95.0 Road curves sharply left into an alluviated valley with the basalt of Round Valley Butte on the left and the basaltic andesites of Susan River on the right. These old calc-alkaline basaltic andesites $(>2,580 \mathrm{ka})$ show little constructional morphology and are thickly mantled 
by soil and by till of older glaciations (70-60 ka or older). 0.8

95.8 Road passes from alluvium onto the basaltic andesites of Susan River. 0.7

96.5 To the right, Lassen County Road 110 on the north side of the Susan River leads to Silver Lake on the east boundary of the Caribou Wilderness. The Caribou Wilderness comprises the highly glaciated, southern part of the Caribou Volcanic Field (fig. 24; see also fig. 10). 0.2

96.7 To the right, U.S. Forest Service Road 10 (also designated as 30N21) on the south side of the Susan River also leads to the Caribou Wilderness. 0.3

97.0 Through the trees to the left, one can catch a quick glimpse of the scoria cone of Bennett Knoll, a calcalkaline basalt. Hidden in the trees south of Bennett Knoll is Clover Butte, also a calc-alkaline scoria cone (K-Ar date $688 \pm 31 \mathrm{ka}$; G.B. Dalrymple, written commun., 1994). 0.2
97.2 Road passes from the andesites of Susan River onto till of older glaciations (60 to $>130 \mathrm{ka}) \mathbf{0 . 6}$

97.8 To the right, U.S. Forest Service Road 30N81 goes to the west along the northern flank of Swain Mountain, a large shield volcano composed of porphyritic olivine basaltic andesite with an age of 1,570 $\pm 35 \mathrm{ka}(\mathrm{K}-\mathrm{Ar}$ determination by G.B. Dalrymple). 0.1

97.9 Lassen County Road A21 passes onto the tholeiitic basalt of Westwood (401 $\pm 7 \mathrm{ka}$; weighted average of five ${ }^{40} \mathrm{Ar} /{ }^{\beta 9} \mathrm{Ar}$ determinations by P.R. Renne and one by B.D. Turrin). The inconspicuous vent for this very extensive basalt flow is hidden in the trees at 9:00, just south of Clover Butte. The tholeiitic basalt of Westwood flows at least 23 miles to the south and southwest into the canyon of the North Fork Feather River, 2.5 miles south of Lake Almanor. For the next 17.4 miles from this point, the field-trip route is on flat upper surface of the tholeiitic basalt of Westwood. 1.0

98.9 View at 12:00 of the andesite of Brush Hill, a calcalkaline edifice probably of late Pliocene age. $\mathbf{0 . 7}$

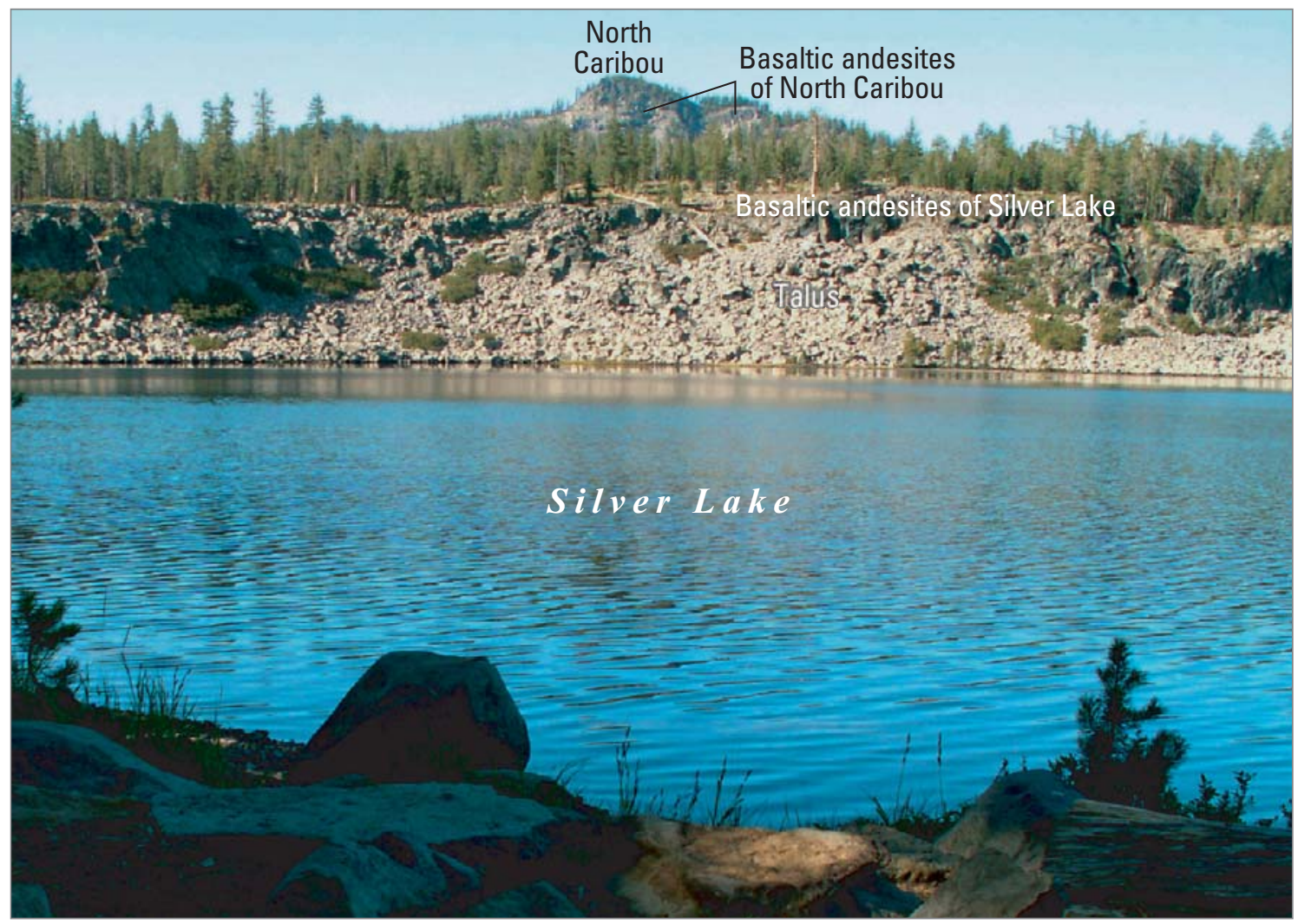

Figure 24. Photograph looking southwest across Silver Lake, illustrating the glaciated physiography of the southern part of the Caribou Volcanic Field. The cliffs on the far side of Silver Lake represent the glaciated flow margin of the basaltic andesites of Silver Lake $(400 \pm 14 \mathrm{ka})$, stripped of surficial vesicular blocks to expose the dense core of the lava flow. The summit of North Caribou is the glaciated agglutinate vent of the basaltic andesites of North Caribou ( 350 ka). Photograph by Carl E. Mortensen. Units generalized from photograph 36 of Muffler and others (2010). 
99.6 To the right is the road to a snowmobile park. $\mathbf{1 . 0}$

100.6 Flow surface of the tholeiitic basalt of Westwood. Note the intermittently preserved surface morphology of this LKOT lava flow. $\mathbf{0 . 9}$

101.5 View at 12:00 of the andesite of Brush Hill. 2.6

104.1 Tumuli on surface of the tholeiitic basalt of Westwood. 3.2

107.3 Lassen County Road A21 crosses Burlington Northern Santa Fe (originally Western Pacific) Railroad and Bizz Johnson National Recreation Trail (to the east towards Susanville; see http:/www.traillink.com/trail/bizz-johnson-national-recreation-trail.aspx). 0.2

107.5 Mountains in distance at 12:00 are composed of Paleozoic metamorphic rocks in the northernmost Sierra Nevada. 2.8

110.3 Junction with Calif. Hwy 36 just northwest of Westwood. Turn right (west) towards Chester and Red Bluff. 0.3

110.6 Calif. Hwy 36 crosses Burlington Northern Santa Fe Railroad. 2.6

113.2 On the left, Calif. Hwy 147 goes south to the community of Clear Creek. 0.5

113.7 Young normal fault (down to west) cutting tholeiitic basalt of Westwood. Lassen Trail crosses the highway at the historical marker just west of the fault. $\mathbf{0 . 2}$

\subsection{Plumas County Line. $\mathbf{1 . 4}$}

115.3 Pass from tholeiitic basalt of Westwood onto tholeiitic basalt of Rock Creek ( $989 \pm 49 \mathrm{ka}$ ). This older basalt has more subdued flow topography and reversed magnetic polarity. 2.1

117.4 Roadcut in tholeiitic basalt of Rock Creek. 0.2

117.6 View at 12:00 of Butt Mountain, to the west of Lake Almanor. Butt Mountain is composed of andesitic rocks related to the Yana Volcanic Center and has an age of $3,320 \pm 80 \mathrm{ka}\left({ }^{40} \mathrm{Ar} /{ }^{39} \mathrm{Ar}\right.$ determination by M.A. Lanphere). 0.8
118.4 At left is Plumas County Road A13, which leads southeast to Hamilton Branch and the Almanor Peninsula. Continue west on Calif. Hwy 36. 0.1

118.5 Contact with the basalts and basaltic andesites of Mud Creek Rim. This thick ( $>400 \mathrm{~m}$ ) section of calc-alkaline lava flows is exposed primarily in fault scarps that form the east boundary of the north part of the Lake Almanor Graben. Four K-Ar ages range from 2,785 $\pm 16 \mathrm{ka}$ to 2,200 \pm 49 ka. 0.7

119.2 Roadcut in basalts and basaltic andesites of Mud Creek Rim. 0.2

119.4 Lat $40^{\circ} 18.73^{\prime}$ N., long $121^{\circ} 11.81^{\prime}$ W. Rest area on left side of highway. Views across Lake Almanor to the Lassen and Maidu Volcanic Centers can be obtained by scrambling through the trees below the rest area. Beyond the rest area, Calif. Hwy 36 angles down a major fault scarp that forms the east boundary of the Lake Almanor Graben. 0.2

119.6 Large roadcut exposes a lava flow with a baked zone at the base and a silicic ash flow. 1.3

120.9 Large roadcut exposes basalts and basaltic andesites of Mud Creek Rim. 0.4

121.3 Turnoffs to North Shore and Last Chance campgrounds. 0.4

121.7 Stop 7: View of Lassen Volcanic Center.

Lat $40^{\circ} 18.73^{\prime} \mathrm{N}$., long $121^{\circ} 11.81^{\prime} \mathrm{W}$. Across the northern arm of Lake Almanor is a beautiful view of Brokeoff Volcano and the Bumpass and Eagle Peak sequences of the Lassen domefield (fig. 25). A few cars can pull off onto the right shoulder of the highway, but be very aware of the fast-moving traffic coming down the fault scarp from the east. Much better parking is on the left (south) side of the highway. Safest access to this parking is to drive west across the causeway into Chester, make a U turn, and drive back to the safe parking on the south side of Calif. Hwy 36. 1.6

123.3 Intersection to right at Fire Station with Feather River Drive, which leads to Plumas County Roads 318 (to Juniper Lake) and 312 (to Warner Valley and Drakesbad, both in LVNP). End of Day 3 road log. 


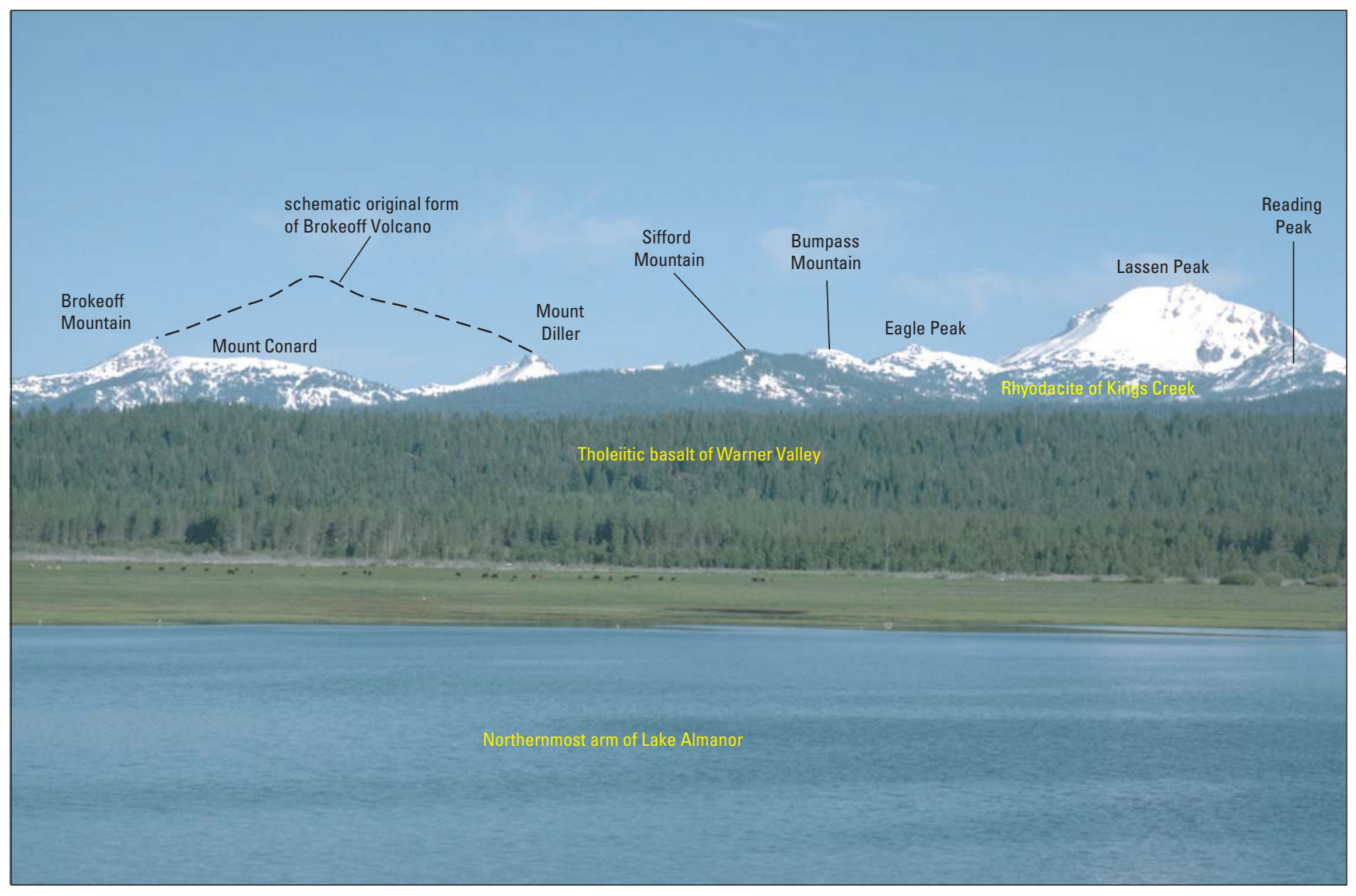

Figure 25. Telephoto view looking northwest from the fault scarp just east of the northernmost part of Lake Almanor. Rocks on Brokeoff Mountain are the dacite of Twin Meadows $(470 \pm 10 \mathrm{ka}$ ), the uppermost unit of the Mill Canyon sequence. Mount Diller consists of the andesite of Mount Diller ( $387 \pm 10 \mathrm{ka})$, part of the Diller sequence. Mount Conard forms the southeast rim of Brokeoff Volcano (>470 ka, part of the Mill Canyon sequence). The higher parts of Brokeoff Volcano (590-390 ka) were destroyed by glacial, landslide, and fluvial erosion; there is no evidence of a cataclysmic eruption or of a caldera. Central skyline is the Lassen Domefield. The dacite of Bumpass Mountain ( $232 \pm 8 \mathrm{ka})$ and the dacite of Reading Peak (212 $\pm 5 \mathrm{ka}$ ) are domes of the Bumpass sequence. The rhyodacite of Eagle Peak (66 $\pm 4 \mathrm{ka})$, the rhyodacite of Kings Creek ( $35 \pm 1 \mathrm{ka})$ and the dacite of Lassen Peak (27 $\pm 1 \mathrm{ka})$ are domes and flows in the Eagle Peak sequence. Sifford Mountain is a calc-alkaline basalt to basaltic andesite volcano ( $170 \mathrm{ka})$ that marks the southern limit of active volcanism in the Cascades Arc. The forested slopes in the foreground are the tholeitic basalt of Warner Valley (610 $\pm 22 \mathrm{ka}$ ). Image is Photograph 2 of Muffler and others (2010).

\section{Day 2 (Chester to Old Station)}

0.0

Intersection at Fire Station of Calif. Hwy 36 with Feather River Drive, which leads to Plumas County Road 318 to Juniper Lake and Road 312 to Warner Valley and Drakesbad, both in LVNP. Trails lead from the warm springs at Drakesbad through beautiful meadows and virgin forest to Boiling Springs Lake and to Devils Kitchen, a high-temperature fumarolic area (Muffler and others, 1982, 1983; Janik and McLaren, 2010;

Ingebritsen and others (2016).

Drive southwest along Calif. Hwy 36 towards Red Bluff. The highway is on outwash gravels of the younger glaciation $(35-17 \mathrm{ka}) . \mathbf{1 . 5}$

1.5 Chester Airport on left. $\mathbf{0 . 2}$
$1.7 \quad$ U.S. Forest Service Almanor Ranger Station on right. $\mathbf{0 . 7}$

2.4 Cross Chester flood control channel, the diversion for the North Fork Feather River. 0.2

2.6 Intersection of Calif. Hwy 36 with Calif. Hwy 89 from the left. Highway 89 goes south down the west side of Lake Almanor to Canyondam, traversing the tholeiitic basalt of Warner Valley $(610 \pm 22 \mathrm{ka})$ and the tholeiitic basalt of Rock Creek ( $989 \pm 49 \mathrm{ka}$ ). These lithologically nearly identical basalts can most easily be distinguished by their different magnetic polarities (the tholeiitic basalt of Rock Creek has reversed polarity). The contact between the two units was mapped using a flux-gate magnetometer.

Continue west on Calif. Hwys 36 and 89. 0.2 
2.8 Calif. Hwys 36 and 89 climb up onto the tholeiitic basalt of Warner Valley $(610 \pm 22 \mathrm{ka})$. This large LKOT flow erupted from vents in vicinity of Mount Harkness in the southern part of LVNP and flowed southward at least 36 miles through the Lake Almanor Graben and into the canyon of the North Fork Feather River. 0.6

3.4 Contact between the tholeiitic basalt of Warner Valley and the basaltic andesite of Stover Mountain, a small shield volcano with a basal diameter of about 5 miles. Stover Mountain is typical of the regional calc-alkaline sequence. It consists of a 1,500-foot-thick sequence of sparsely porphyritic olivine basaltic andesite lava flows. The volcano is old and eroded, has no preserved vent areas, and is covered by a thick soil. Stover Mountain has an age of $1,937 \pm 39 \mathrm{ka}$ (K-Ar determination by M.A. Lanphere). 0.5

3.9 Roadcuts in the basaltic andesite of Stover Mountain. On the left for the next few miles, through the trees, one can glimpse andesites of the northern part of the Yana Volcanic Center (3.4-2.4 Ma). 5.0

8.9 Tehama County line. Highway passes onto the tholeiitic basalt of Ice Cave Mountain ( $\sim 65 \mathrm{ka})$. The vent for this young LKOT flow is 6 miles to the north at Ice Cave Mountain. The flow went south down the valley of Lost Creek to this point and then split into two lobes, one flowing southeast for another 3 miles to Soldier Meadows and the other flowing west for 3.5 miles to Deer Creek Meadows. The tholeiitic basalt of Ice Cave Mountain overlies outwash gravel of the older glaciations ( $>130$ to $60 \mathrm{ka}$ ) and underlies outwash gravels of the younger glaciation $(35-17 \mathrm{ka}) . \mathbf{0 . 9}$

9.8 Hamlet of Saint Bernard. 0.6

10.4 Roadcut in the distal toe of the rhyodacite of Gurnsey Creek ( 1.3 Ma). This thick lava flow of coarsely porphyritic augite-hypersthene rhyodacite erupted from a vent several miles to the northwest and flowed east from the east flank of Maidu Volcanic Center. $\mathbf{0 . 5}$

10.9 Deer Creek restaurant. The highway continues northwest along the contact between outwash gravels of the older glaciations to the north and the tholeiitic basalt of Ice Cave Mountain to the south. 2.0

12.9 At left is Calif. Hwy 32, which leads south along Deer Creek between the Yana Volcanic Center to the east and the Maidu Volcanic Center to the west (see Section C of Muffler and Clynne, 2015). Inconspicuous outcrops at the junction and along Gurnsey Creek $0.5 \mathrm{mi}$ west and south expose the Rockland tephra, part of the Rockland caldera complex of the Lassen Volcanic Center. The Rockland tephra was erupted at
$609 \pm 7 \mathrm{ka}$ (Lanphere and others, 1999, 2004) from a small caldera now filled by younger rocks of the Lassen Volcanic Center (fig. 8). 0.3

13.2 View at 12:00 of the rhyolite of Lost Creek Plateau. For the next 7 miles to the north, the highway is in a broad valley cut in the rhyodacite of Gurnsey Creek (volume $\left.\sim 2 \mathrm{~km}^{3}\right)$. Overlying the rhyodacite of Gurnsey Creek on the right (east) is the rhyolite of Lost Creek Plateau $\left(\sim 5 \mathrm{~km}^{3} ; 1,305 \pm 10 \mathrm{ka}\right)$ and on the left (west) the rhyolite of Mill Creek Plateau $\left(\sim 7 \mathrm{~km}^{3}\right)$. These huge silicic flows, along with the rhyolite of North Stover Mountain $\left(\sim 8.5 \mathrm{~km}^{3}\right)$ and the rhyolite of Blue Ridge $\left(15 \mathrm{~km}^{3}\right)$, comprise the youngest part of the Maidu Volcanic Center and have an aggregate volume of $\sim 37 \mathrm{~km}^{3} .0 .6$

13.8 Bridge over Gurnsey Creek. To the left of the highway are exposures of one of the tholeiitic basalts of Mill Creek Plateau (140-100 ka). This basalt flow erupted from a vent 4 miles to the northwest, flowed northeast off the Mill Creek Plateau, and then south along Gurnsey Creek. Highway is on top of this flow for the next $1.3 \mathrm{mi} . \mathbf{0 . 8}$

14.6 Fire Mountain Lodge. $\mathbf{0 . 5}$

15.1 Bridge over Gurnsey Creek. Gurnsey Creek Campground to the right. In the bed of the creek just northwest of the bridge are outcrops of the tholeiitic basalts of Mill Creek Plateau. The valley of Gurnsey Creek for the next 5 miles is choked with glacial outwash and with colluvium from the friable rhyolite and rhyodacite flows that form the bluffs to the east and west. 1.1

16.2 View at 12:00 of the light-colored rhyolite of Mill Creek Plateau. 2.1

18.3 View at 11:30 of Brokeoff Mountain, part of the west rim of Brokeoff Volcano. This volcano $(\sim 590-385 \mathrm{ka})$ is part of the Lassen Volcanic Center. 0.4

18.7 To the right is Tehama County Road 769 to Wilson Lake. 1.8

20.5 Stop 8: View of Brokeoff Volcano. Lat $40^{\circ} 21.62^{\prime}$ N., long $121^{\circ} 29.67^{\prime} \mathrm{W}$. Pull off on the right at the Childs Meadows Resort. To the north, up Mill Creek, the view is into the core of Brokeoff Volcano, which is composed of the Mill Canyon sequence (590-470 ka). A similar but better view is shown in fig. 26, taken from lat $40^{\circ} 23.23^{\prime} \mathrm{N}$., long $121^{\circ} 30.19^{\prime} \mathrm{W}$., atop a prominent cliff on the east side of Mill Canyon 1.8 miles north of Childs Meadows.

The prominent peak in the left distance is Brokeoff Mountain (9,235 ft; 2,816 m), which forms the southwest rim of Brokeoff Volcano. Brokeoff Mountain consists 


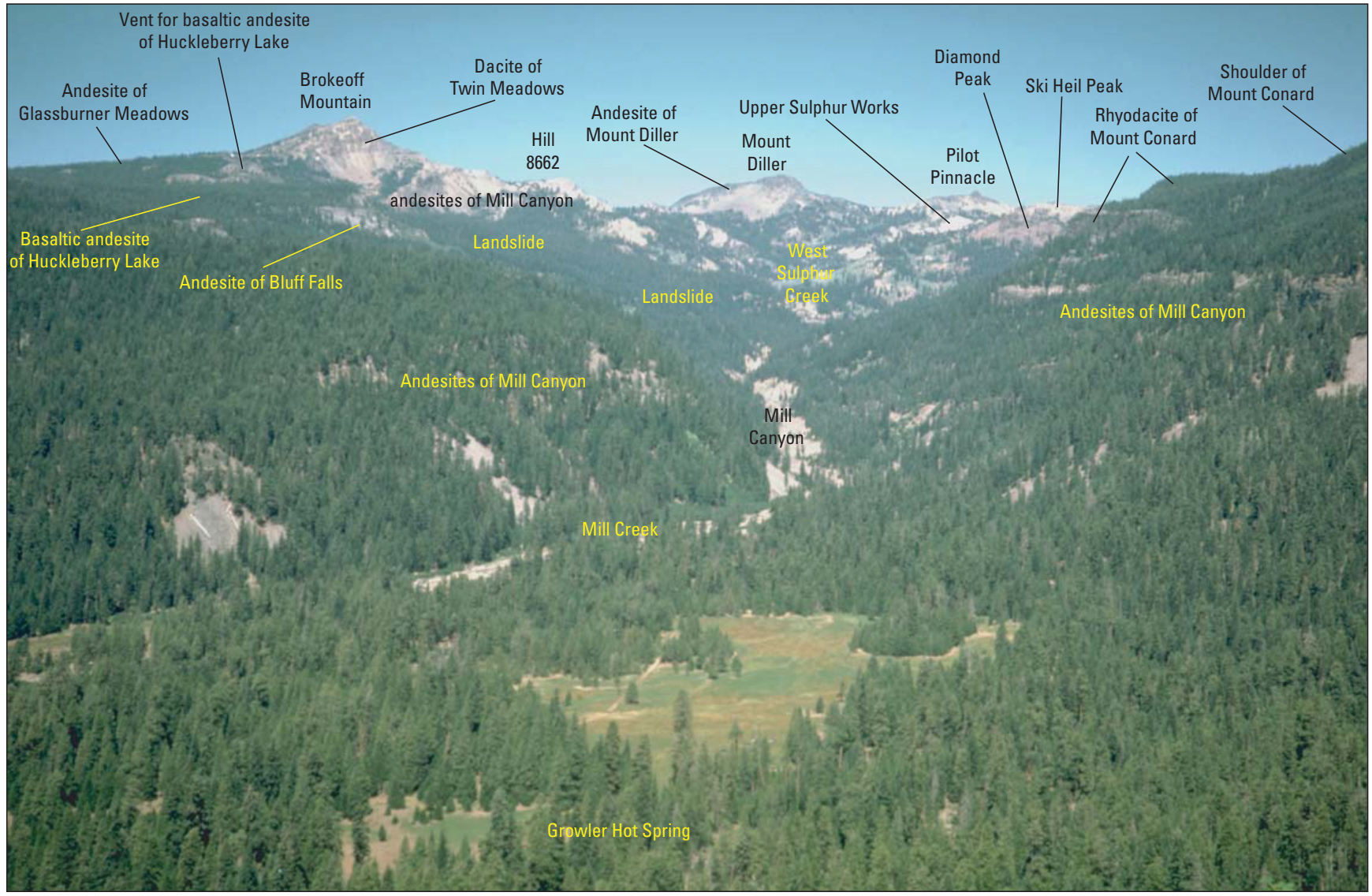

Figure 26. View looking north from cliffs on east side of Mill Creek, 1.8 mi northeast of Childs Meadows. The andesites of Mill Canyon (590-470 ka) in the core of Brokeoff Volcano (including Diamond Peak) consist of interbedded flows and breccias (many hydrothermally altered). The volcano is highly eroded by glacial, fluvial and landslide processes (the major landslide, visible in the photo, has a ${ }^{14} \mathrm{C}$ date of $3,310 \pm 55$ years B.P.). Brokeoff Mountain, Mount Diller, Pilot Pinnacle, and Mount Conard mark the resistant rim of the erosional amphitheater in Brokeoff Volcano. The cliffs on Brokeoff Mountain are the dacite of Twin Meadows ( $470 \pm 10 \mathrm{ka})$, the uppermost unit of the Mill Canyon sequence. Mount Diller and Pilot Pinnacle consist of the andesite of Mount Diller (387 $\pm 10 \mathrm{ka})$, part of the Diller sequence. The andesite of Glassburner Meadows ( 450 ka) and the andesite of Bluff Falls quarry (467 $\pm 10 \mathrm{ka})$ are also part of the Diller sequence. These units are overlain by the basaltic andesite of Huckleberry Lake ( $300 \mathrm{ka})$, a regional calc-alkaline unit unrelated to Brokeoff Volcano. The dacite of Ski Heil Peak $(244 \pm 10 \mathrm{ka}$ ) and the rhyodacite of Mount Conard $(298 \pm 9 \mathrm{ka})$ are part of the Bumpass sequence of the Lassen domefield. Upper Sulphur Works is the site of many acid fumaroles and represents major steam upflow from the vapor-dominated reservoir of the Lassen hydrothermal system (see fig. 11). The underlying hot-water reservoir flows south and is discharged in the near-neutral, chloride-bearing, silica-depositing springs of Growler Hot Spring and nearby Morgan Hot Springs. Image is photograph 4 of Muffler and others (2010).

primarily of the dacite of Twin Meadows $(470 \pm 10 \mathrm{ka})$, the uppermost unit of the Mill Canyon sequence. On the dip slope just to the left of the summit of Brokeoff Mountain is the overlying andesite of Mount Diller ( $387 \pm 10 \mathrm{ka})$, one of six thick, large-volume, resistant lava flows that erupted from flank vents between 470 and $385 \mathrm{ka}$.

In the right distance is Mount Conard, which forms the southeast rim of Brokeoff Volcano. Mount Conard consists of flows and breccias of the Mill Canyon sequence. On the west flank of Mount Conard is the rhyodacite of Mount Conard (298 $\pm 9 \mathrm{ka})$, part of the Bumpass sequence of the Lassen domefield.

To the left of Mill Canyon in the middle ground is Morgan Mountain (out of figure 25 to the left), one of several dacite domes emplaced at $\sim 800 \mathrm{ka}$ as part of the Rockland caldera complex of the Lassen Volcanic Center.

The cliffs to the east of Childs Meadows consist of the andesite of Wild Cattle Mountain ( 2.0-1.6 Ma), part of Stage 1 of the Dittmar Volcanic Center. The mountain south-southwest of Childs Meadows consists of the andesite of Doe Mountain (1.6-1.4 Ma; part of Stage 2 of the Dittmar Volcanic Center). 0.4

20.9 Highway passes through a small, geologically complex area containing andesites of Stage 1 of the Maidu Volcanic Center, the andesite of Doe Mountain, and a sliver of the andesite of Wild Cattle Mountain. 0.2 
21.1 Cross Mill Creek. 2.5 miles to the north up Mill Creek on private land are Morgan and Growler Hot Springs, both characterized by near-neutral-pH, chloridebearing boiling water that deposits siliceous sinter and pyrite. These springs represent outflow from the deep, $240{ }^{\circ} \mathrm{C}$ hot-water reservoir beneath the vapor-dominated system that feeds the fumarole areas such as Sulphur Works and Bumpass Hell in Lassen Volcanic National Park (Muffler and others, 1982; Ingebritsen and Sorey, 1985; Clynne and others, 2003; Janik and McLaren, 2010; Clynne and others, 2012).

Mill Creek and Deer Creek are the two major remaining free-running, salmon-spawning streams flowing into the Sacramento Valley. 0.4

21.5 Junction with Calif. Hwy 172, which loops south to the community of Mill Creek and then northwest to rejoin Calif. Hwy 36 at the town of Mineral. West of the junction, Calif. Hwys 36 and 89 climb up the south flank of Morgan Mountain and cross onto a large patch of till of older glaciations (>130-60 ka). 1.9

\subsection{Passing lane. 0.2}

23.6 Pass from till of older glaciations onto the andesites of Maidu Volcanic Center, Stage 1 ( 2.4 to $\sim 2.15 \mathrm{Ma}) . \mathbf{0 . 3}$

23.9 Pass onto white, hydrothermally altered dacites of the Maidu Volcanic Center, Stage 2 ( 2.15 to $\sim 2.05 \mathrm{Ma})$. This alteration was produced by a shallow fossil acidsulfate magmatic-hydrothermal system (John and others, 2005). 0.8

\subsection{Till of older glaciations. $\mathbf{0 . 2}$}

\subsection{Rest area at Morgan Summit (5,750 feet). 0.1}

25.0 Intersection of Calif. Hwy 36 to Red Bluff and Calif. Hwy 89. Turn right (north) onto Hwy 89 towards Lassen Volcanic National Park.

To the right (east) for the next 1.4 miles is the dacite dome of Morgan Mountain, one of the dacite domes of the Rockland caldera complex. The valley to the left (west) between Christie Hill and Morgan Mountain is filled by the basaltic andesite of Huckleberry Lake ( 300 ka), which erupted from a vent high on the flank of the extinct Brokeoff Volcano. This flow represents a return of the regional mafic volcanism after the extinction of Brokeoff Volcano about 385 ka. 2.3

27.3 Roadcut to left exposes till of younger glaciation ( $\sim 25-17 \mathrm{ka}) . \mathbf{1 . 6}$

28.9 Stop 9: Bluff Falls quarry (fig. 27). To visit this quarry (lat $40^{\circ} 24.85^{\prime} \mathrm{N}$. , long $121^{\circ} 32.00^{\prime} \mathrm{W}$.), park on the right at lat $40^{\circ} 24.82^{\prime} \mathrm{N}$., long $121^{\circ} 31.92^{\prime} \mathrm{W}$., walk $\sim 200 \mathrm{ft}$ north, cross the highway carefully, and climb up the slope just north of the small stream.

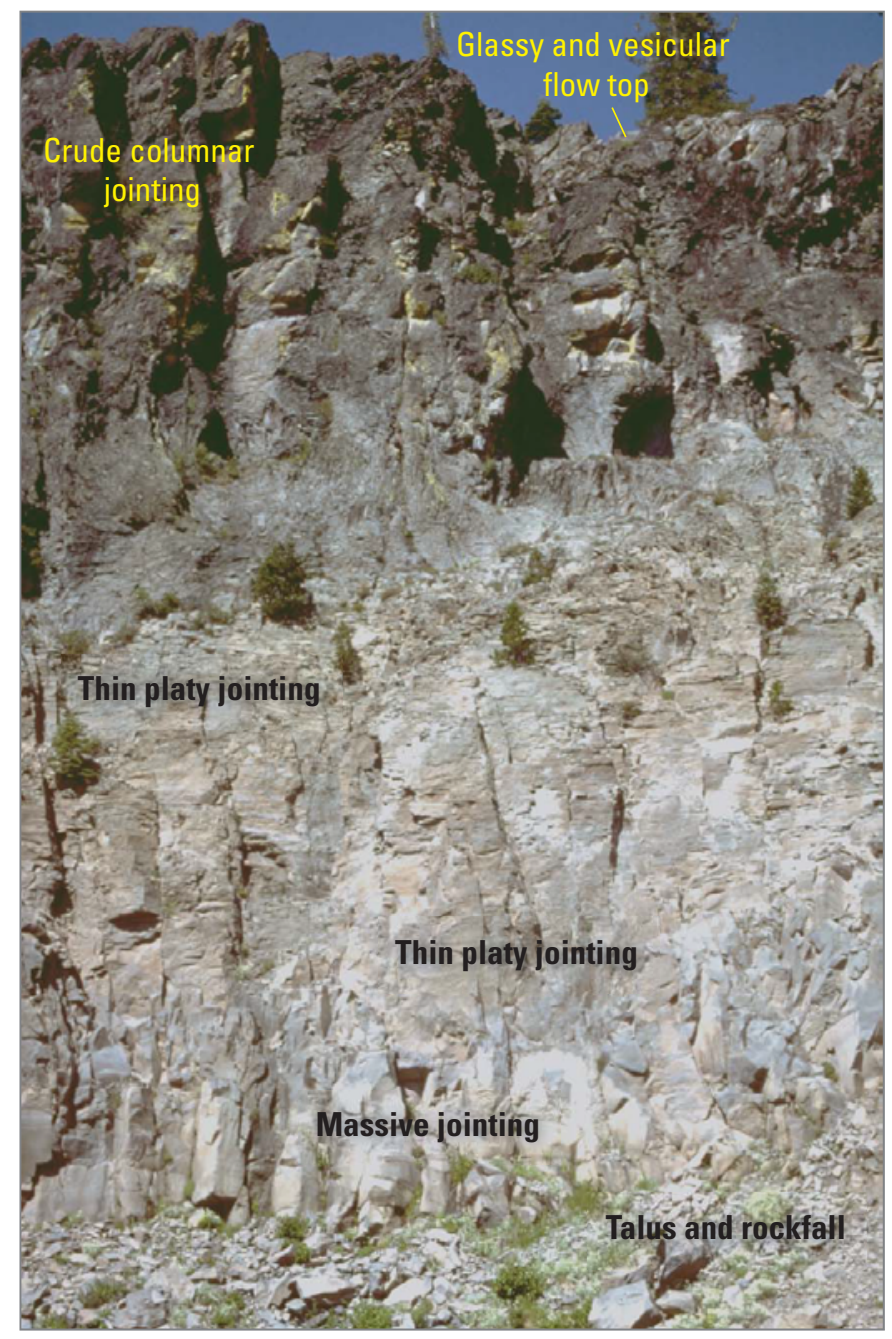

Figure 27. Photograph looking west at andesite flow exposed in the face of Bluff Falls quarry, just west of Calif. Hwy 89, 0.8 mile south of the south entrance to Lassen Volcanic National Park. The glacially carved cliff, modified by quarrying, exposes nearly the entire thickness of the andesite of Bluff Falls quarry ( $467 \pm 10 \mathrm{ka}$ ), a typical silicic andesite flow from the Diller sequence of Brokeoff Volcano. The base of the flow (not exposed here) consists of a thin, reddened, scoriaceous flow breccia that is overlain by a massively jointed, faintly flow-banded glass-rich zone. This zone grades upward into a thick zone of thin platy jointing. In the flow interior, platy jointing is nearly horizontal to slightly wavy, but at flow edges it can be ramped upward or highly contorted. On the glaciated flanks of Brokeoff Volcano, the orientation of platy jointing can be used to map flow edges and flow direction. The platy-jointed interior of the flow grades upward into a zone of crude columnar joints superimposed on the platy jointing. The upper surface of the flow is glassy and vesicular. The color change halfway up the cliff marks the base of the natural exposure. Large blocks at bottom of the photograph are $1-2 \mathrm{~m}$; cliff is $\sim 50 \mathrm{~m}$ high. Image is Photograph 12 of Clynne and Muffler (2010). 
This glacially carved cliff exposes nearly the entire thickness of the andesite of Bluff Falls quarry (467 $\pm 10 \mathrm{ka})$, a typical andesite lava flow of the Diller sequence of Brokeoff Volcano. The upper part of Brokeoff Volcano, called the Diller sequence (470$385 \mathrm{ka}$ ), is composed of six thick, laterally extensive lava flows, generally lacking intercalated fragmental deposits. Although different in detail, each unit of the Diller sequence is a porphyritic augite-hypersthene andesite containing about $30-40$ percent phenocrysts, dominantly plagioclase, and is difficult to distinguish from other units of the Diller sequence. Sparse olivine is commonly present and xenocrystic amphibole rarely so. Flows of the Diller sequence are characterized by abundant $\mathrm{mm}$ - to $\mathrm{cm}$-size glomeroporphyritic clots of the phenocryst minerals, but with slightly different compositions. The clots commonly display solidstate recrystallization of orthopyroxene from olivine as well as exsolution features in pyroxenes; the clots have been interpreted as cognate crystals derived from cumulates (Clynne, 1990). Larger inclusions with gabbroic bulk compositions are sparse, and quenched magmatic inclusions like those in Lassen domefield rocks are rare.

The major-element compositions of lavas in the Diller sequence range from about 58 to 63 percent $\mathrm{SiO}_{2}$ (fig. 9) and can be nicely modeled by crystal fractionation of average calc-alkaline basalt (Clynne, 1990) of the Lassen area. Incompatible trace-element abundances, however, increase much more rapidly in the models than they do in the lava suite, and addition of a high-silica component low in incompatible elements is required for the models to be viable. Addition of about 10 percent of a rhyolite melt remarkably similar to rhyolite lava flows found in the Lassen area satisfies this requirement. 1.6

30.5 Entrance station for Lassen Volcanic National Park. Just beyond is the Kohm Yah-mah-nee Visitor Center, with exhibits, gift shop, restaurant, and rest rooms. The entrance station and the visitor center are located on a large landslide that, $3,310 \pm 55$ years ago, moved $7 \mathrm{~km}$ down Mill Creek from the cliff at the base of Brokeoff Mountain. Reactivation of a small part of this landslide on January 2, 1997, temporarily blocked the park road just south of the entrance station. 1.0

31.5 Stop 10: Sulphur Works. Lat $40^{\circ} 26.92^{\prime}$ N., long $121^{\circ} 32.12^{\prime} \mathrm{W}$. Turn left into the parking lot and walk east along Calif. Hwy 89. Sulphur Works is an area of fumaroles, boiling pools, mudpots, and steaming ground; it is the most accessible of the thermal areas in LVNP. Expansion of the thermal area has forced removal of a boardwalk that used to lead north across the thermal area. Visitors can, however, take the first 300 feet of the trail to Ridge
Lakes for several good overlooks of the thermal area. Most of the area above Sulphur Works northward to Mount Diller comprises dozens of old landslides of hydrothermally altered lava flows and pyroclastic rocks (fig. 28).

Temporal and spatial variation of fumaroles has been observed in all thermal areas of Lassen Volcanic Park, but it has been most systematically documented in recent years at Sulphur Works. From 2004 to 2011 (fig. 29), fumarolic activity north of Calif. Hwy 89 migrated south towards the road and became concentrated in a large boiling mudpot adjacent to the sidewalk curb (fig. 30). In addition, borings into the roadbed by the Federal Highway Administration in April 2009 and November 2011 demonstrated that boiling temperatures have risen to a depth of 15-20 ft (5-6 m) under Calif. Hwy 89 , compromising the integrity of the roadbed. This situation led to extensive road repairs in the spring of 2013, the most recent of several road reconstructions across this treacherous area over the past 75 years. $\mathbf{1 . 4}$

32.9 Stop 11: Diamond Peak. Lat $40^{\circ} 26.68^{\prime}$ N., long $121^{\circ} 31.18^{\prime} \mathrm{W}$. Pull far off the road into the parking area on the right. Be careful crossing the road to examine the roadcut because visibility is restricted on this corner.

This viewpoint is near the center of Brokeoff Volcano. Virtually all the rocks that can be seen (fig. 31) are at least incipiently altered, and most areas in the core of the volcano are strongly to totally altered to propylitic and argillic assemblages related to fossil magmatichydrothermal systems at temperatures of 200 to $>300$ ${ }^{\circ} \mathrm{C}$ (Crowley and others, 2004; John and others, 2006). Unaltered rock is preserved only in dense, glassy, basal parts of lava flows. Flows and breccias on Diamond Peak dip steeply eastward, indicating that the summit vent of Brokeoff Volcano at the time of their eruption was nearby to the west. To the south, in the glacial valley of Mill Creek, the base of Brokeoff Volcano is exposed where it overlies rocks of Maidu Volcanic Center. Mill Canyon and the flanks of Brokeoff Mountain expose rocks representing nearly the complete history of Brokeoff Volcano. Thick flank flows of olivine-augite and hypersthene-augite andesite can be correlated across Mill Canyon with no offset by faulting. The triangleshaped peak of Brokeoff Mountain to the west is resistant to erosion by virtue of the thick flow of pyroxenehornblende dacite (the dacite of Twin Meadows; $470 \pm 10$ $\mathrm{ka})$ that ended the Mill Canyon sequence (590-470 ka). To the southeast, flows and breccias of the Mill Canyon sequence form most of Mount Conard. The cliff forming the prominent shoulder above Mill Canyon is a thick hornblende-biotite rhyodacite lava flow of the Bumpass sequence of the Lassen domefield. This flow followed the course of a canyon cut in rocks of the Mill Canyon sequence. The rhyodacite flow is dated at $298 \pm 9 \mathrm{ka}$ and 


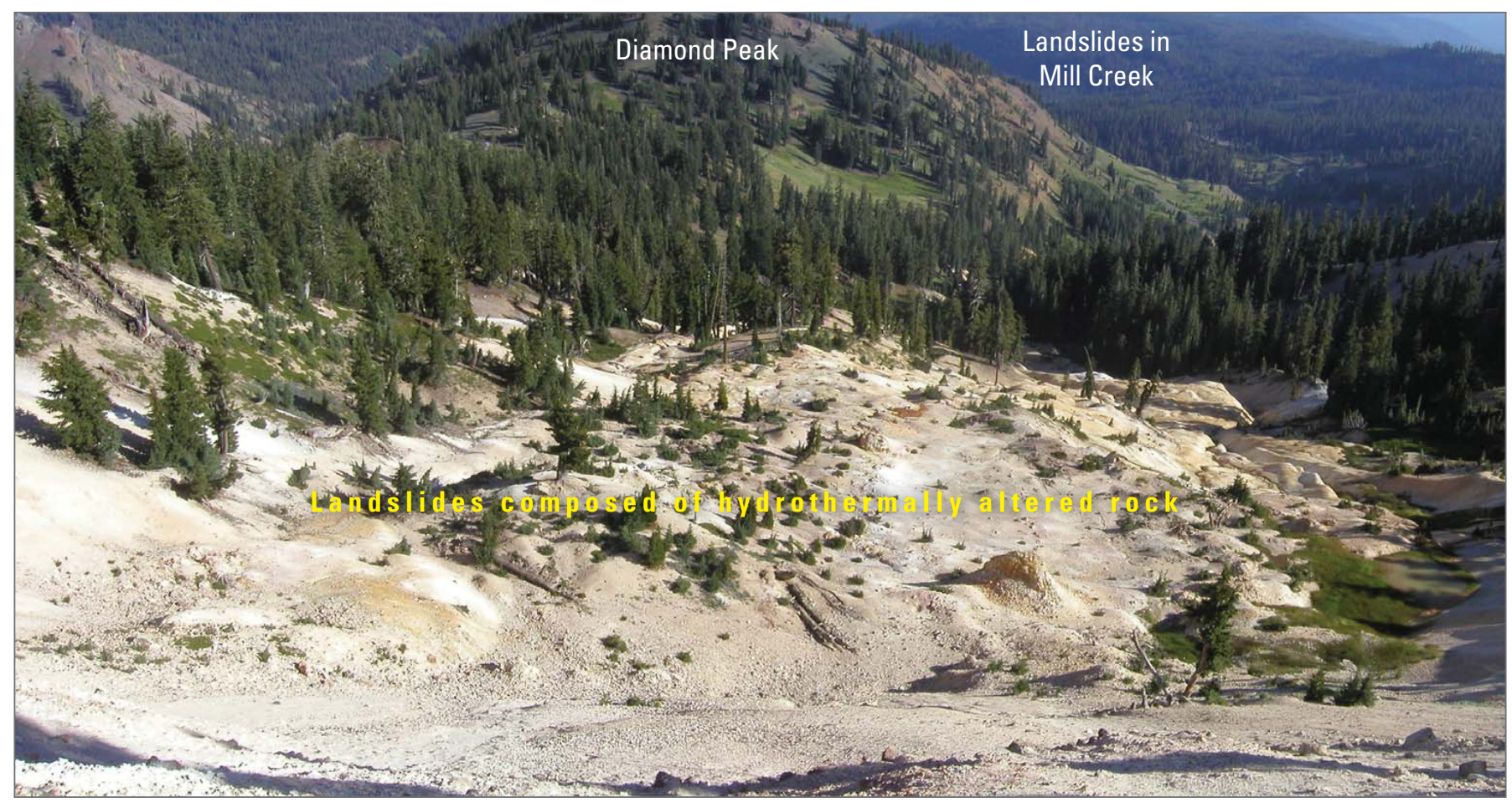

Figure 28. Photograph showing landslides in hydrothermally altered volcanic rocks. View looking southeast over active landslides in the area south of Pilot Pinnacle (out of the photograph to the left) and northwest of Diamond Peak. Most of the central area of Brokeoff Volcano is covered by these young landslides, which form in clay-rich, hydrothermally altered volcanic rock and are most active during the annual spring snowmelt. From figure 18 of Clynne and others (2012).

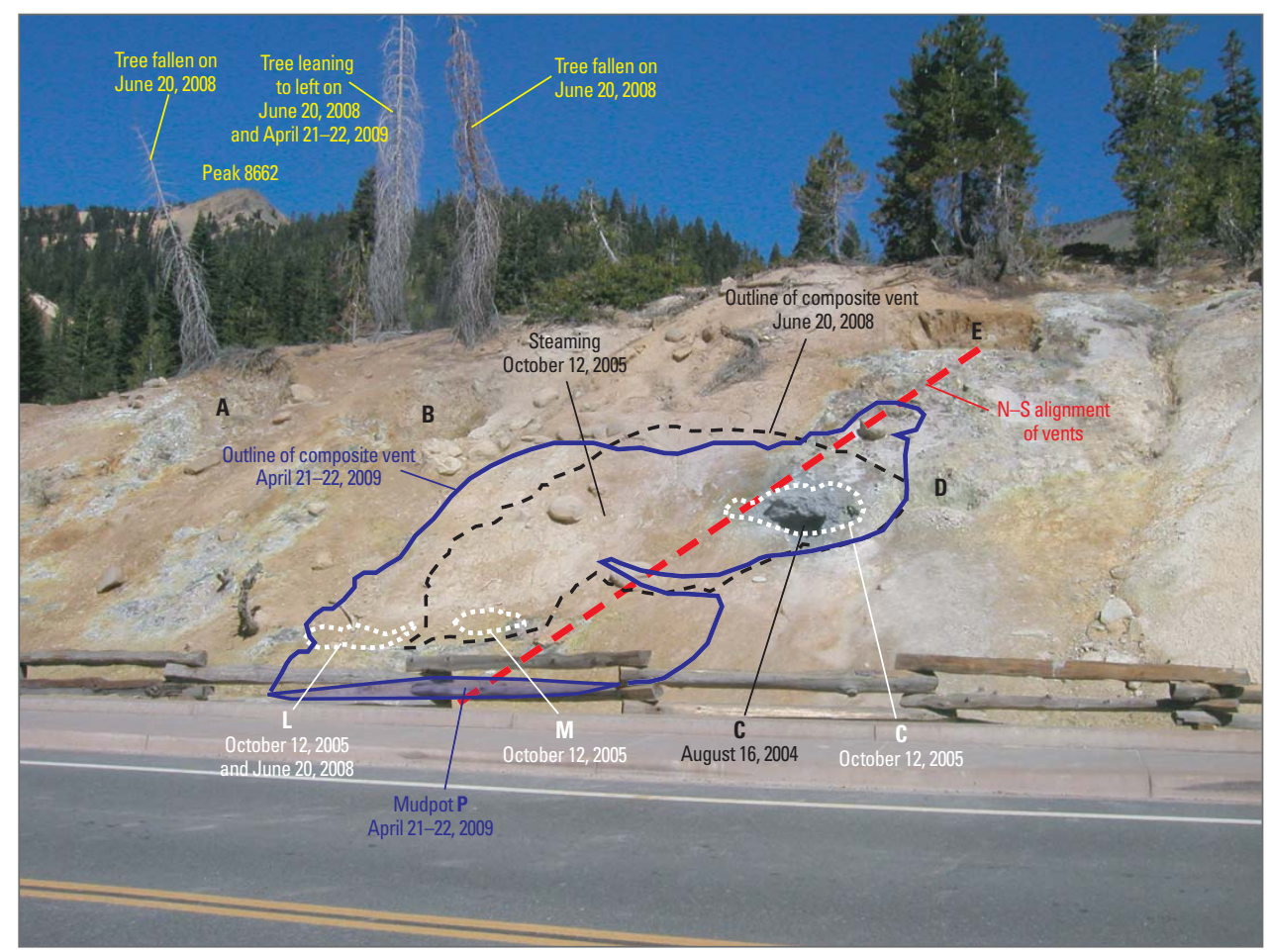

Figure 29. Annotated photograph showing changes of hydrothermal features at Sulphur Works from 2004 to 2005, 2008, and 2009. Photograph taken August 16,2004 , looking at $300^{\circ}$ azimuth across Calif. Hwy 89. Dotted white lines denote vents that were either enlarged (C) or new (L and M) as of October 12, 2005. Short-dashed black line represents the boundary of the large vent resulting from the collapse of the area between vent $M$ and vent $C$, sometime between October 16, 2005, and June 20, 2008, probably in the winter of 2007-2008. Vents $A, B, D$, and E were essentially unchanged from August 2004 to June 2008. By April 2009, the large vent of 2008 had expanded further (solid blue line) and had developed into a vigorous mudpot just north of the fence and sidewalk (see fig. 30). Red dashed line represents north-south alignment of vents in 2009. 
Figure 30. Photograph taken in November 2011 of mudpot $P$ (see fig. 2) north of Calif. Hwy 89 at Sulphur Works. The fence shown in figure 29 was just to the left of the curb at the lower right of the photograph.
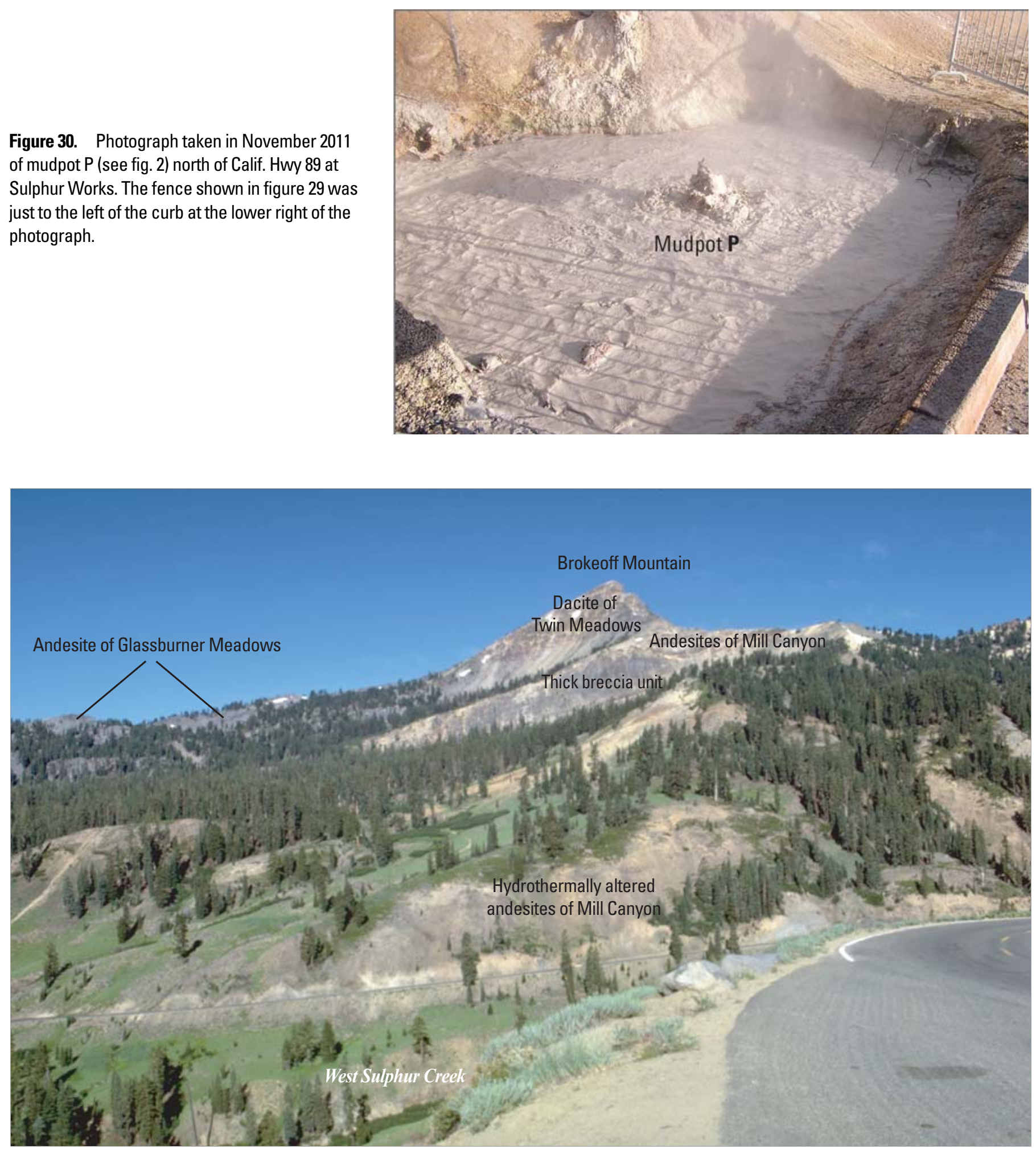

Figure 31. Photograph of Brokeoff Mountain looking west from turnout on Calif. Hwy 89 south-southwest of Diamond Peak, approximately at the center of Brokeoff Volcano. Foreground to middle ground consists of incipiently to strongly altered lava flows and fragmental deposits of the andesites of Mill Canyon, with many postglacial $(<15 \mathrm{ka}$ ) landslides. Brokeoff Mountain forms the southwest remnant of Brokeoff Volcano and consists primarily of the dacite of Twin Meadows ( $470 \pm 10 \mathrm{ka}$ ), the uppermost unit of the Mill Canyon sequence. The overlying andesite of Mount Diller (387 $\pm 10 \mathrm{ka})$, part of the Diller sequence, crops out at and beyond the summit of Brokeoff Mountain and is barely visible in this photograph. The andesite of Glassburner Meadows ( $450 \mathrm{ka}$ ) is also part of the Diller sequence. The prominent cliff in the thick breccia unit of the andesites of Mill Canyon marks the scarp of the large landslide that, 3,310 \pm 5 years ago, moved $7 \mathrm{~km}$ to the left (south) down Mill Canyon. Photograph 6 of Muffler and others (2010). 
illustrates the amount of erosion in the core of Brokeoff Volcano since that time.

The exposure in this roadcut is typical of the Mill Canyon sequence (590-470 ka), the lower part of Brokeoff Volcano. The Mill Canyon sequence is composed of packages of thin lava flows and intercalated fragmental deposits, including agglomerates (like this exposure), breccias, and lahars. Adjacent packages of flows can have very different phenocryst abundances, phenocryst assemblages, and bulk composition. The lavas are mostly a diverse array of porphyritic andesites. Phenocryst assemblages are generally plagioclase-dominated and include combinations of olivine, augite, and hypersthene. Sparse porphyritic dacites have augitehypersthene or hypersthene-hornblende assemblages. Abundant evidence for magma mixing includes resorption of phenocrysts, as well as reverse zoning, overgrowth rims, and compatible-element spikes in mafic phenocrysts. Small glomeroporphyritic clots of the phenocryst minerals are present in some Mill Canyon lavas, but are never as abundant as in the Diller sequence. Larger inclusions with gabbroic bulk compositions are sparse, and quenched magmatic inclusions like those in Lassen domefield rocks are absent.

The major-element compositions of lavas of the Mill Canyon sequence range from about 54 to 68 percent $\mathrm{SiO}_{2}$ (fig. 4), although most are 56-60 percent $\mathrm{SiO}_{2}$. As with the Diller sequence, they can be nicely modeled by crystal fractionation of average Lassen area calc-alkaline basalt (Clynne, 1990; see discussion at Stop 9). The lavas and fragmental deposits of the Mill Canyon sequence evolved in a magmatic system that processed small increments of magma and thus erupted a diverse array of lithologies. Compared to the Mill Canyon sequence, the larger-volume eruptions, less heterogeneous lithologies, and less evidence for mineralogic disequilibrium argue that the Diller sequence erupted from a magmatic system that was more mature and better integrated than during Mill Canyon time.

Pullouts over the next 2 miles provide excellent views of the east wall of Little Hot Springs Valley. Prominent are thin to thick lava flows of the andesites of Mill Canyon, part of the Mill Canyon sequence in the interior of Brokeoff Volcano. Permeable fragmental deposits are preferentially altered to light colors compared to the dark cores of lava flows. Overlying the andesites of Mill Canyon is the less-altered andesite of Mount Diller (387 $\pm 10 \mathrm{ka}$, part of the Diller sequence). Steam vents and acid springs are abundant in landslide deposits along the floor of Little Hot Springs Valley. 2.6

35.5 White, kaolinite-rich altered andesite of the Mill Canyon sequence of Brokeoff Volcano at sharp bend in road. $\mathbf{0 . 6}$
36.1 Just before the south end of Emerald Lake, the road crosses the contact between the uppermost preserved rocks of Brokeoff Volcano and the augite-hornblende dacite dome of Ski Heil Peak (244 \pm 10 ka; part of the Bumpass sequence of the Lassen domefield). Straight ahead, Eagle Peak is a hornblende-biotite rhyodacite dome (66 $\pm 4 \mathrm{ka}$; part of the Eagle Peak sequence of the Lassen domefield) that was preceded by a lava flow (the cliffs ringing the base of the dome) and a pyroclastic flow (which mantles Ski Heil Peak and is exposed distally just northwest of LVNP). 0.4

36.5 Stop 12: Bumpass Hell parking lot. Lat $40^{\circ} 27.98^{\prime}$ N., long $121^{\circ} 30.85^{\prime} \mathrm{W}$. Walk out to the south end of the parking lot for excellent views of Brokeoff Volcano and the Bumpass and Eagle Peak sequences of the Lassen domefield. The parking lot is built on the contact between lava flows of the Diller sequence of Brokeoff Volcano and overlying dacites of the Bumpass sequence. Note the glacial striations and glacial erratics; the prominent 4-m boulder (fig. 32) is hornblende-augite dacite from Bumpass Mountain.

To the southwest and south is the eroded core of Brokeoff Volcano, with the Maidu Volcanic Center in the distance. To the east is the hornblende-augite dacite of Bumpass Mountain (232 $\pm 8 \mathrm{ka})$. All the dacite domes of the Bumpass sequence have suffered extensive glacial erosion. Although the overall shapes of the domes have not been greatly modified, few traces of an outer glassy or pumiceous carapace or talus mantle are preserved. The view to the north is dominated by the weakly glaciated dacite dome of

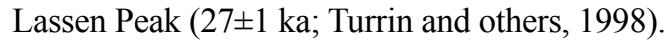

A gentle, level, 1.2-mi (2-km) trail winds southeast from the parking lot to Bumpass Hell, the major thermal area in this part of the park. The trail lies along the contact between the Diller sequence and the Bumpass sequence. Shortly after leaving the parking lot, one can see well-preserved glacial striae and polish on the massive dacite of Bumpass Mountain dome. The middle part of the trail has been blasted from the massively jointed devitrified interior of the dome. At the viewpoint where the trail turns east, $0.55 \mathrm{mi}(0.85 \mathrm{~km})$ from the parking lot (see photograph 7 of Muffler and others (2010), andesite of the Diller sequence is exposed, and a National Park Service exhibit shows a model of Brokeoff Volcano before erosion. Farther along the trail, explosion breccia related to emplacement of the dacite of Bumpass Mountain is prominently exposed.

Bumpass Hell (fig. 33) marks a major thermal upflow (37 \pm 5 megawatts; Sorey and Ingebritsen, 1995) of the Lassen geothermal system. Bumpass Hell is located at the vent for the dacite of Bumpass Mountain along the contact with the Diller sequence of Brokeoff Volcano. 


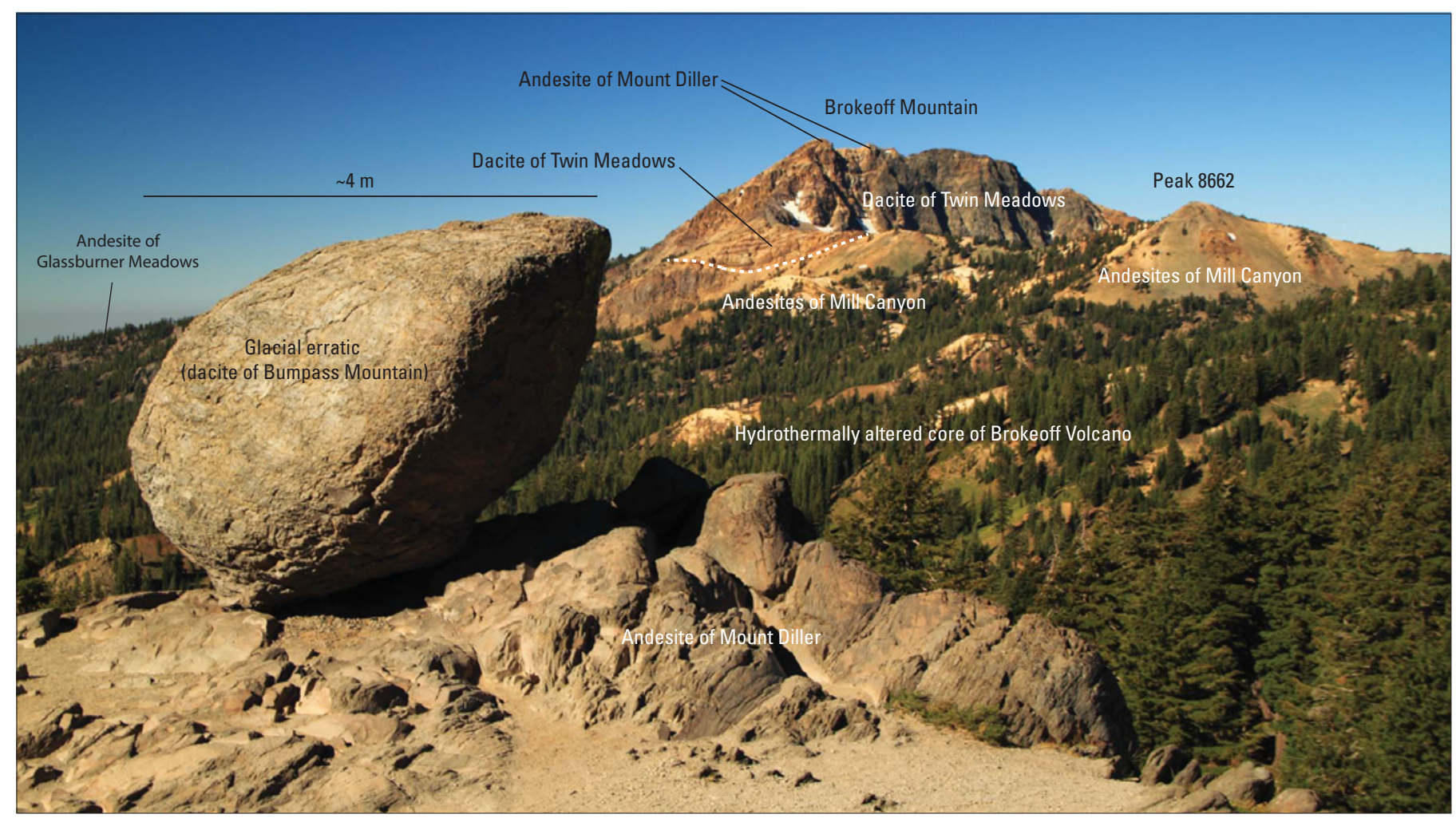

Figure 32. Photograph looking southwest at a glacial erratic of the dacite of Bumpass Mountain resting on polished and striated andesite of Mount Diller. At the summit of Brokeoff Mountain is the andesite of Mount Diller, dipping away from the camera and underlain by a thick section of the dacite of Twin Meadows. The white dashed line marks the approximate contact with the underlying andesites of Mill Canyon, which comprise the eroded core of Brokeoff Volcano. The white patches among the trees are altered rocks related to fossil hydrothermal systems (Crowley and others, 2004; John and others, 2006). Photograph by R. Forrest Hopson, with annotations by Michael A. Clynne.

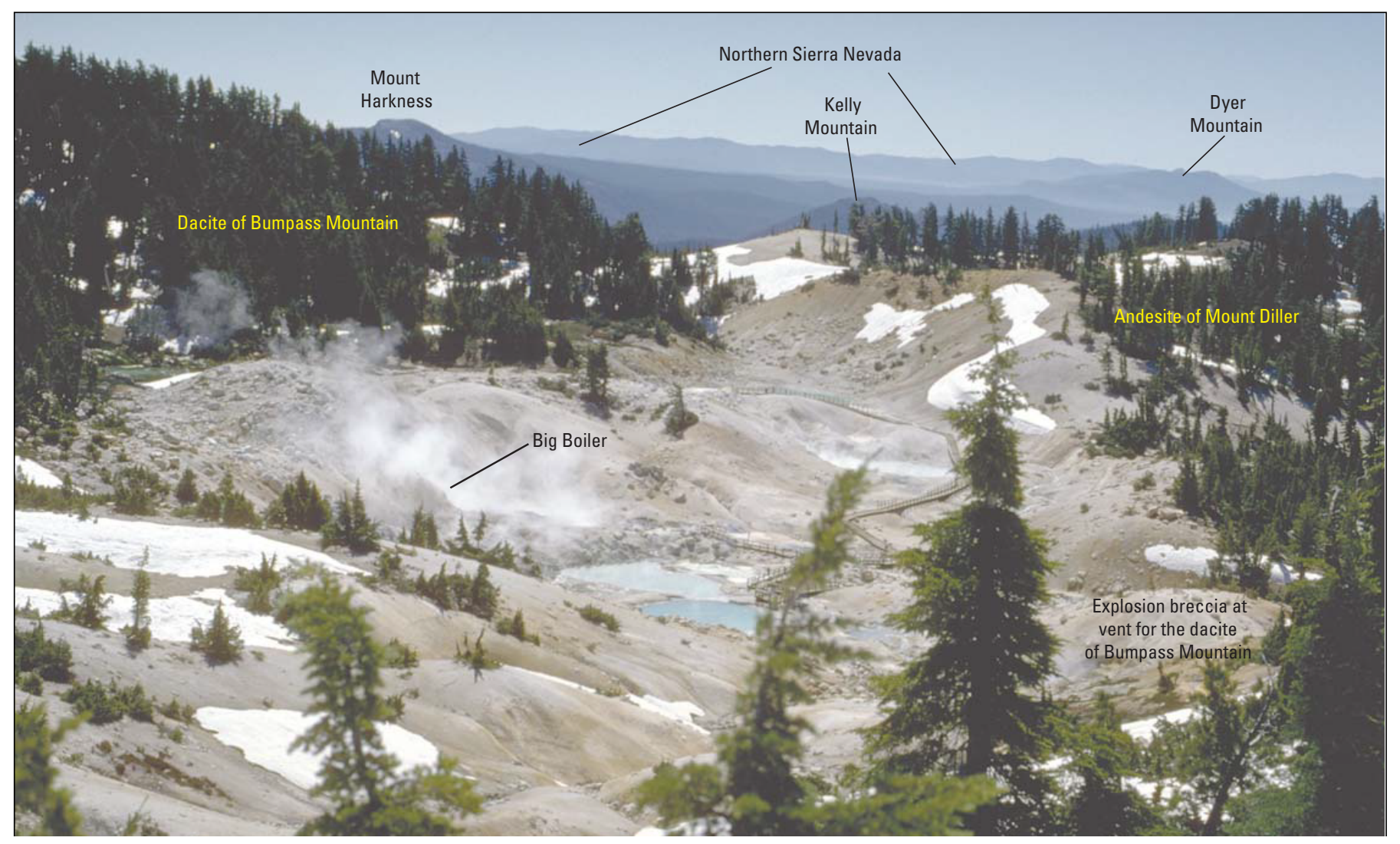


Bumpass Hell contains numerous superheated fumaroles (Muffler and others, 1982), one of which had a temperature in the summer of 1988 of $161.4^{\circ} \mathrm{C}$ (Clynne and others, 2003). Boiling of the $240^{\circ} \mathrm{C}$ hot water in the reservoir provides the steam that feeds the surface features. Approximately 75 major fumaroles, acidsulfate hot springs, and mudpots, plus myriad smaller features, occur in an area of approximately $0.13 \mathrm{~km}^{2}$ that is intensely altered to an aggregate of opal and kaolinite. Much of the surface of the active part of Bumpass Hell is covered with orange and yellow sulfates; many steam vents are lined with bright-yellow native sulfur. Pyrite is common as linings of the vents and discharge channels, as scum floating on the surface of pools, and as dispersions in gray or black mudpots.

The acid-sulfate water from Bumpass Hell is typical of hot springs related to a vapor-dominated reservoir in having low $\mathrm{pH}$, high sulfate concentrations, and no significant $\mathrm{Cl}$. Most other thermal areas in LVNP have thermal features and chemistry similar to Bumpass Hell and are also manifestations of the vapor-dominated reservoir. Some springs just below Sulphur Works (see photograph on page 4 of Clynne and others, 2003), in upper Little Hot Springs Valley, and at Drakesbad are relatively rich in $\mathrm{HCO}_{3}^{-}$(bicarbonate) and deposit travertine (calcium carbonate) or a mixture of silica and travertine. These springs are interpreted to be surface discharge from the zone of steam condensate that overlies the vapor-dominated reservoir (Muffler and others, 1982). 0.6

37.1 For the next 0.4 mile the road passes through the dacite of Mount Helen (249 $\pm 12 \mathrm{ka}$ ), a lava dome of the Bumpass sequence. This glaciated dome contains very abundant quenched mafic inclusions (Feeley and others, 2008b). See Stop 15 (Chaos Crags) for a discussion of the origin and significance of quenched mafic inclusions. To the west is Lake Helen, in a cirque of the younger glaciation. 0.7

37.8 Lat $40^{\circ} 28.42^{\prime}$ N., long $121^{\circ} 30.32^{\prime}$ W. Lassen Peak parking lot. The large parking lot marks the start of an excellent trail that gains $1,950 \mathrm{ft}(600 \mathrm{~m})$ in elevation as it switchbacks for $2.5 \mathrm{mi}(4 \mathrm{~km})$ to the summit of
27 \pm 1 -ka Lassen Peak (Eagle Peak sequence of the Lassen domefield) at 10,457 ft (3,187 m). Although outer, pumiceous material has been removed by glaciation, Lassen Peak is still an impressively large dacite dome with a volume approaching $2 \mathrm{~km}^{3}$, about 10 times the size of the composite dome at Mount St. Helens. The dacite of Lassen Peak has an unusual and distinctive phenocryst assemblage consisting of plagioclase, hornblende, biotite, quartz, augite, and olivine. The sparse augite and olivine were derived from disaggregation of the abundant quenched mafic inclusions in the dacite (see petrologic discussion of quenched mafic inclusions at Stop 15). Paleomagnetic work by Duane Champion (Turrin and others, 1998) indicates that Lassen Peak was emplaced over a short period of time, perhaps as little as 5 years.

At the summit of Lassen Peak (fig. 39), one can observe the 1915-17 eruption craters and deposits (see 1:2,500-scale geologic map of the summit area in Christiansen and others, 2002) and on a clear day have good views of the Sierra Nevada, Sacramento Valley, Coast Ranges, Klamath Mountains, Mount Shasta, and the Medicine Lake highlands. To the west of the parking lot is the hornblende-augite dacite dome of Lassen Peak parking lot (260-250 ka), part of the Bumpass sequence. Glacial erosion has exposed intricate flow banding in the margin of the dome. On the east side of the parking lot, a small tuff cone marks the vent for the hornblende-biotite rhyodacite lava flow and pyroclastic flows of Kings

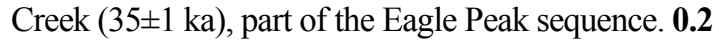

38.0 This pass at 8,511 $\mathrm{ft}(2,594 \mathrm{~m})$ is the crest of the Cascade Range in this area. To the right is the glaciated biotite-hornblende dacite dome of Mount Helen $(249 \pm 12 \mathrm{ka})$, rich in quenched mafic inclusions. On the left is the rhyodacite flow of Kings Creek. Much of the pumiceous glassy carapace and structure of the flow is preserved because it has not been heavily glaciated. Directly ahead, the next roadcut exposes thick breccia at the base of the flow. To the right beyond Mount Helen is the hornblende-augite dacite dome and flow complex of Bumpass Mountain (232 $\pm 8 \mathrm{ka}$ ) and a short, stubby, biotite-hornblende dacite lava flow from Mount Helen. 0.7

Figure 33. View looking east-southeast from trail at the west end of Bumpass Hell. Bumpass Hell is the surface expression of the major upflow from the vapor-dominated reservoir of the Lassen hydrothermal system (Muffler and others, 1982; Ingebritsen and Sorey, 1985; Janik and McLaren, 2010). Bumpass Hell contains many fumaroles, mud pots, and acid hot springs (Muffler and others, 1983). "Big Boiler" is a superheated fumarole (temperatures up to $161^{\circ} \mathrm{C}$; Clynne and others, 2003). Bumpass Hell lies along the contact between the dacite of Bumpass Mountain (232 $\pm 8 \mathrm{ka}$; part of the Bumpass sequence of the Lassen domefield) and the andesite of Mount Diller (387 $\pm 10 \mathrm{ka}$; part of the Diller sequence of Brokeoff Volcano). At lower right is the explosion breccia at the vent for the dacite of Bumpass Mountain. Mount Harkness $(188 \pm 32 \mathrm{ka}$ ) is a small calc-alkaline basalt and andesite volcano that marks the southern limit of active volcanism in the Cascades Arc. Kelly Mountain is part of the Dittmar Volcanic Center (2,300-1,300 ka). Dyer Mountain is composed of Paleozoic metasedimentary rocks and is part of the northern Sierra Nevada. 
38.7 View of Reading Peak, a deeply glaciated, dacite dome complex $(212 \pm 5 \mathrm{ka})$ of the Bumpass sequence. Before being eroded by glaciers, the Reading Peak complex was probably bigger than Lassen Peak. To the right and in the distance behind Reading Peak are Mount Harkness (a late Pleistocene basaltic andesite shield volcano), Kelly Mountain (a remnant of the 2.4-1.3 Ma Dittmar Volcanic Center), and Sifford Mountain, a basalt to basaltic andesite shield volcano (172 $\pm 23 \mathrm{ka}$ and $167 \pm 4 \mathrm{ka})$. Sifford Mountain is the southernmost young regional volcano in the Cascades Arc and marks the approximate southern limit of active volcanism in the Lassen area. Over the past 2.5-3 m.y., the southern limit of active volcanism has migrated $27 \mathrm{~km}$ to the north from the vicinity of the Yana Volcanic Center (about $1 \mathrm{~cm} / \mathrm{yr}$ ). The broad, flat plateau to the east of Sifford Mountain is a thick lava flow that is part of the dacite of Bumpass Mountain (232 $\pm 8 \mathrm{ka}) .0 .7$

39.4 Lat $40^{\circ} 28.49^{\prime}$ N., long $121^{\circ} 29.88^{\prime}$ W. A set of linear cracks extends from here northwest across the Kings Creek lava flow but cannot be traced into adjacent rock units. The en echelon segments define a zone of extension $1.1 \mathrm{~km}$ long. Segment widths range from a few meters to a few tens of meters, and there is no vertical offset. Opening took place after the Chaos Crags eruption at $1,103 \pm 13$ years B.P. ( $\sim 850$ C.E.) and before the 1915 eruption of Lassen Peak. The most likely origin of the cracks is extension above a propagating dike that did not quite reach the surface. The cracks might be related to the 1915 eruption of Lassen Peak. 1.8

41.2 Excellent view of Lassen Peak at 12:00, Mount Helen at 10:30, and Bumpass Mountain at 9:30. The shoulder to the left of Bumpass Mountain is the Diller sequence of Brokeoff Volcano. Further to the left is Mount Conard, composed of andesites of the Mill Canyon sequence. 2.0

43.2 Lat $40^{\circ} 07.63^{\prime}$ N., long $121^{\circ} 27.60^{\prime}$ W. Cross Kings Creek. To the left is the $212 \pm 5 \mathrm{ka}$ dacite dome of Reading Peak. To the right is the large dacite flow $(232 \pm 8 \mathrm{ka})$ that vented at Bumpass Mountain.

The trail to Kings Creek Falls begins here and winds through delightful meadows and past beautiful cascades as Kings Creek descends through the thick dacite flow. Kings Creek Falls is just beneath the dacite flow, where the creek plunges over a thick lava flow of the augite-hypersthene andesite of Rice Creek (485 $\pm 12 \mathrm{ka}$ and $477 \pm 14 \mathrm{ka}$ ), part of the Diller sequence of Brokeoff Volcano. 0.8

44.0 The skyline to the east, visible through the trees for the next 2.7 miles, is the Caribou Volcanic Field, an intensely glaciated area of more than 100, mostly small, late Pleistocene basalt to andesite volcanoes. Volcanism in the Caribou Volcanic Field began $\sim 425 \mathrm{ka}$ and was especially active from 400 to $300 \mathrm{ka}$ and from $110 \mathrm{ka}$ to the present. Conspicuous volcanic peaks in the Caribou Volcanic Field are Red Cinder, North Caribou, and South Caribou. 1.3

45.3 Elevation $7,000 \mathrm{ft}(2,134 \mathrm{~m})$. For the next $0.75 \mathrm{mi}$, volcanic vents of the Central Plateau are visible to the right through the trees. Rocks of the Central Plateau are all hybrid andesites of the Twin Lakes sequence that erupted from vents on the periphery of the more central Bumpass and Eagle Peak sequences. The hybrid andesite magmas formed by mixing approximately equal amounts of dacite magma from beneath the domefield and calc-alkaline basaltic magma responsible for the regional volcanism. Hybrid andesite lava flows are thick, cover large areas, and are characterized by the coexistence of olivine and quartz. These rocks were called quartz basalts by Finch and Anderson (1930) and by Williams (1932). The two youngest volcanic events in Lassen Volcanic National Park, Cinder Cone (1666 C.E.) and the 1915 eruption at the summit of Lassen Peak, are hybrid andesites of the Twin Lakes sequence. At 12:00 is Hat Mountain, a 50-40 ka hybrid andesite. Most of the Central Plateau visible from here consists of the thick lava flows from Hat Mountain. Exposed along the road is monolithologic till derived from Reading Peak. 1.6

46.9 Turnoff to right to south shore of Summit Lake. $\mathbf{0 . 4}$

47.3 Ranger station on East Fork Hat Creek. For the next 2.5 miles, the road passes through till of younger glaciations (35-17 ka) derived from Reading Peak, with sporadic outcrops of a $193 \pm 11$ ka lava flow, the dacite of Dersch Meadows, which is the youngest dacite of the Bumpass sequence. 2.4

Cross West Fork Hat Creek. 0.4

\subsection{Stop 13: Devastated Area parking lot.}

Lat $40^{\circ} 27.91^{\prime} \mathrm{N}$., long $121^{\circ} 27.91^{\prime} \mathrm{W}$. From the Devastated Area parking lot, first look southwest towards Lassen Peak. The May 1915 eruptions at the summit of Lassen Peak destroyed the $\mathrm{mi}^{2}\left(8 \mathrm{~km}^{2}\right)$ Devastated Area (Clynne and others, 2014). The mature conifer forest that covered the area (fig. 34) was completely destroyed by the eruptions of May 1915 (figs. 35 and 36). Compare figure 34 with the vigorously growing trees that now cover the area.

Next, follow the gentle trail to the north of the parking lot to observe the deposits from the May 1915 eruptions. Note that the large "Hot Rock" in the Loomis photographs (figs. 35 and 36) can still be seen adjacent to the trail, but views of the Devastated Area are now obscured by trees.

Modern field and laboratory studies (Clynne, 1999; Christiansen and others, 2002) have produced a 

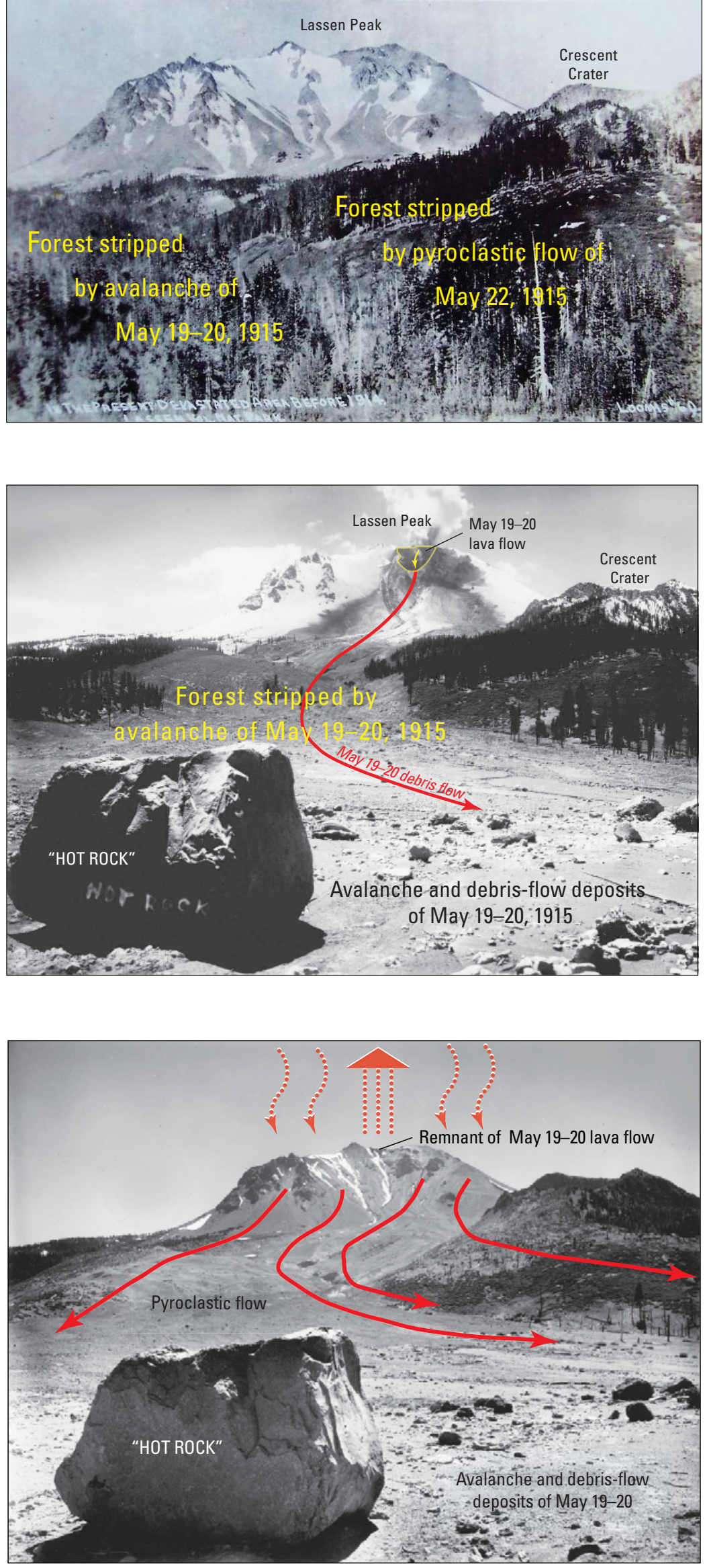

Figure 34. Photograph of the northeast flank of Lassen Peak taken by B.F. Loomis in June 1913, before the 1914-1917 eruption. The photograph looks southwest and shows the forest subsequently stripped by the eruptions of May 1915 (see figs. 35 and 36 ). Annotations by L.J.P. Muffler and M.A. Clynne.

Figure 35. Photograph of the Devastated Area taken by B.F Loomis on the morning of May 22, 1915 , before the subplinian eruption at $\sim 4$ p.m, later that day. The photograph shows the path of the avalanche and debris flow of May 19-20. Note that the northeast lobe of the May 19-20 lava flow at the summit of Lassen Peak is still in place. Annotations by L.J.P. Muffler and M.A. Clynne.

Figure 36. Photograph showing the Devastated Area after the eruption of May 22, 1915. Taken by B.F. Loomis in June 1915, the photograph shows the path of the pyroclastic flow produced by the Plinian eruption of $\sim 4: 00 \mathrm{pm}$ on May 22, 1915. Note the much wider zone of devastation compared to that of May 19-20 (fig. 35). Also, the May 19-20 lava flow high on the northeast flank of Lassen Peak is almost entirely gone. Vertical dashed lines indicate diagrammatically the subplinian eruption column. Curved dashed lines indicate diagrammatically the column collapse. Solid red lines indicate path of pyroclastic flow. Annotations by L.J.P. Muffler and M.A. Clynne. 
revised scenario of the May 1915 eruptions of Lassen Peak (fig. 37).

The eruptive sequence began on May 30, 1914, with a phreatic explosion at the top of Lassen Peak. By mid-May of 1915, more than 180 steam explosions had blasted out a 300-m-long crater at the summit (Day and Allen, 1925). In the week before May 19, 1915, a small dacite lava dome filled the crater. On the late evening of May 19, 1915, the growing dacite dome was disrupted by a large explosion. Hot blocks of lava thrown onto the snow-covered upper flanks and summit of Lassen Peak initiated an avalanche of snow and rock that swept down the steep northeast face of Lassen Peak, over the low till ridge northeast of Emigrant Pass, and into Hat Creek (fig. 38). The avalanche was quickly followed by a debris flow generated by melting of snow by the hot dacite lava blocks and incorporation of underlying loose rock debris. The debris flow followed the same path as the avalanche until it encountered the low till ridge northeast of Emigrant Pass, where it was deflected west into Lost Creek and flowed another $10 \mathrm{~km}$ to about $3 \mathrm{~km}$ west of Twin Bridges (the confluence of Hat and Lost Creeks). During the early morning hours of May 20, 1915, the debris-flow and avalanche deposits released large volumes of water that caused a flood along Hat Creek north of Old Station. Also in the late evening and early morning of May 19-20, 1915, dacite lava, which was less viscous than that erupted during the previous week, welled up into and filled the newly excavated crater. It spilled over two low spots on the rim and emplaced two short lava flows on the steep west and northeast flanks of Lassen Peak (Christiansen and others, 2002; Clynne and others, 2014).

The eruptive sequence culminated two days later at approximately 4:00 p.m. on May 22, 1915. A vertically directed column of pumice and gas blasted through the May 19-20 lava flow, created a new crater, and rose to $30,000 \mathrm{ft}$ ( $6 \mathrm{mi} ; 9 \mathrm{~km})$. Partial collapse of the eruption column initiated a pyroclastic flow on the northeast slope of Lassen Peak, which rapidly incorporated and melted snow in its path. By the time the pyroclastic flow reached the lower Devastated Area, it had transformed into a

\section{Spring of 1917}

- Steam blast activity excavates a new crater at the summit of Lassen Peak

May 22, 1915

- Small debris flows on all flanks of Lassen Peak

- Explosive eruption of dacite pumice generates a pyroclastic flow on the northeast flank of Lassen Peak; melting of snow transforms the pyroclastic flow into a fluid debris flow that goes down Lost Creek and generates a second flood in Hat Creek Valley; ash falls as far east as Elko, Nevada

May 19-20, 1915

- Dacite lava flow emplaced at the summit of Lassen Peak

- Explosive disruption of the dome generates an avalanche of hot dacite and snow down the northeast flank of Lassen Peak; melting of snow transforms the avalanche to a debris flow that goes north along Lost Creek and causes a flood in the Hat Creek Valley

May 14-19, 1915

- Black lava dome fills crater

\section{May 30, 1914 to mid May 1915}

- More than 180 steam blast eruptions excavate a crater $\sim 300 \mathrm{~m}(1,000 \mathrm{ft})$ in length at the summit of Lassen Peak

Figure 37. Chart giving a summary of events in the 1914-1917 eruptions of Lassen Peak. In stratigraphic order: earliest event at bottom; latest event at top. From Clynne and others (2014). 


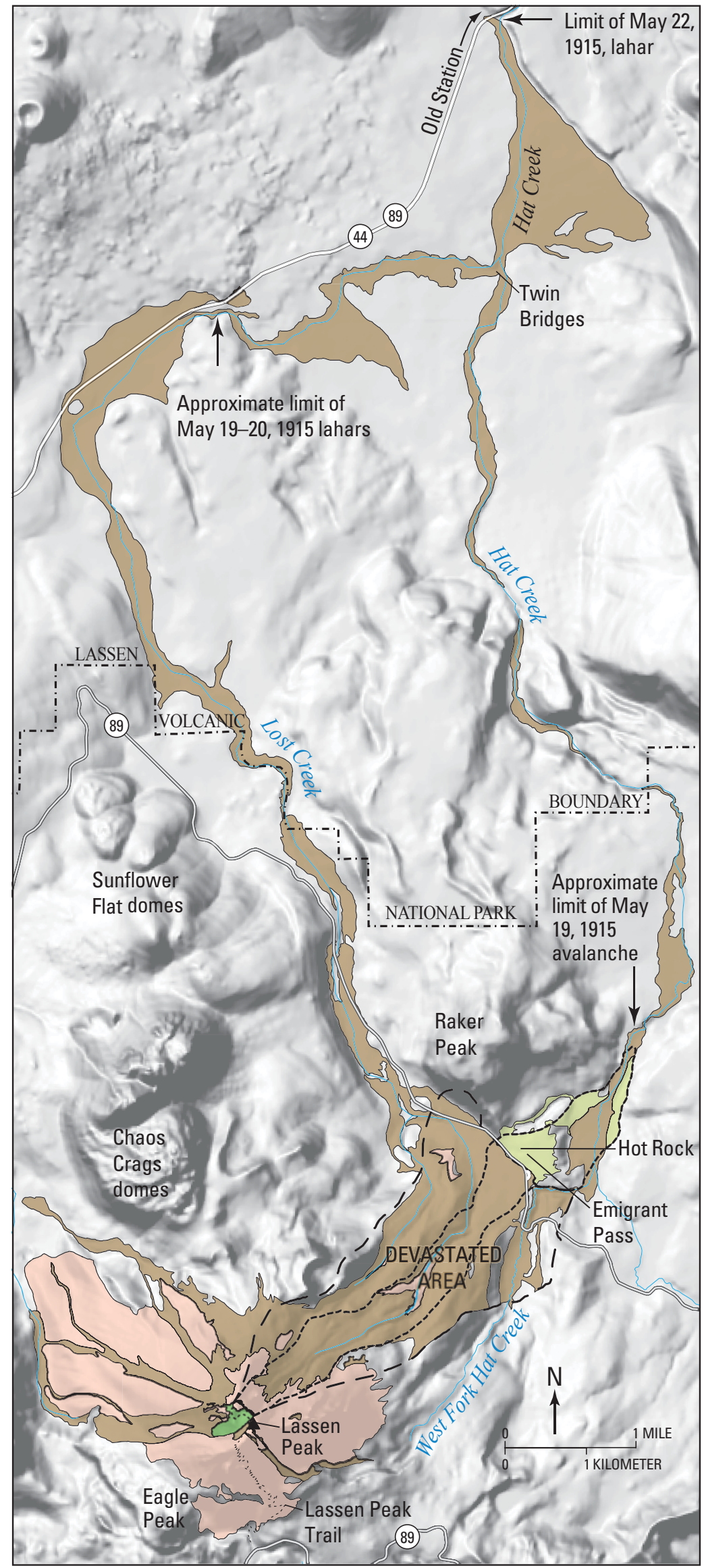

\section{EXPLANATION}

\section{May 22, 1915 Deposits}

Pyroclastic flow and related lahars

May 19-20, 1915 Deposits

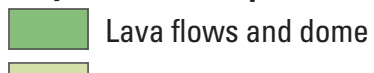

Avalanche and lahar

\section{Lassen Peak lava dome 27,000 years old \\ ...... Lassen Volcanic National Park boundary}

Tree blow-down limits

- - May 22, 1915

------ May 19-20, 1915

(89) California state highway

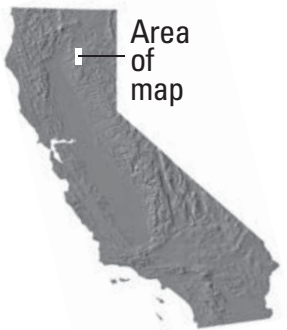

Figure 38. Generalized geologic map of deposits from the May 1915 eruptions at the summit of Lassen Peak. Map adapted from Clynne and others (2014), in turn taken from plate 1 of Christiansen and others (2002) and plate 1 of Clynne and Muffler (2010). 
fluid debris flow that traveled down Lost Creek to Twin Bridges, where it released water and caused a second flood along Hat Creek north of Old Station. Fallout from the eruption cloud emplaced a pumice deposit on the upper slopes of Lassen Peak and a thin fallout lobe directed northeast towards Cinder Cone. Ash fall was recorded as far away as Elko, Nevada, $280 \mathrm{mi}(450 \mathrm{~km})$ to the east. Pumice that fell on remaining snow-covered areas high on Lassen Peak generated six viscous debris flows that were emplaced on the west, north, and east flanks of Lassen Peak. The May 19-20 lava flow on the northeast flank of Lassen Peak was removed in this eruption and incorporated into May 22 deposits, and the still-hot lava at the summit partially slumped back into the May 22 crater (fig. 39). Only a small, dark fragment of this flow can be seen from the Devastated Area parking lot in the notch at the top of Lassen Peak (fig. 40). In contrast, the entire May 19-20 lava flow on the west flank of Lassen Peak can be seen today (fig. 41).
For several years after the 1915 eruption, spring snowmelt percolating into Lassen Peak encountered hot rock and triggered steam explosions. Particularly vigorous phreatic explosions in May 1917 blasted out the northwestern of the two craters at the summit of Lassen Peak and emplaced phreatic deposits high on the west flank of Lassen Peak. The craters continued to emit substantial amounts of steam into the 1950s. Today, on cold days, one can still find a few weakly steaming vents. Despite the widespread effects of the 1915 eruption, the total volume erupted was small, about $0.03 \mathrm{~km}^{3}$.

In the May 1915 eruptions, four types of volcanic rock were produced:

- black dacite (64-65 percent $\mathrm{SiO}_{2}$ ) erupted as a lava dome between May 14 and 19 and as a lava flow (64-65 percent $\mathrm{SiO}_{2}$ ) emplaced on May 19-20 (fig. 42A)

- unbanded light-colored pumice (64-68 percent $\mathrm{SiO}_{2}$ ) erupted on May 22 (fig. 42B)

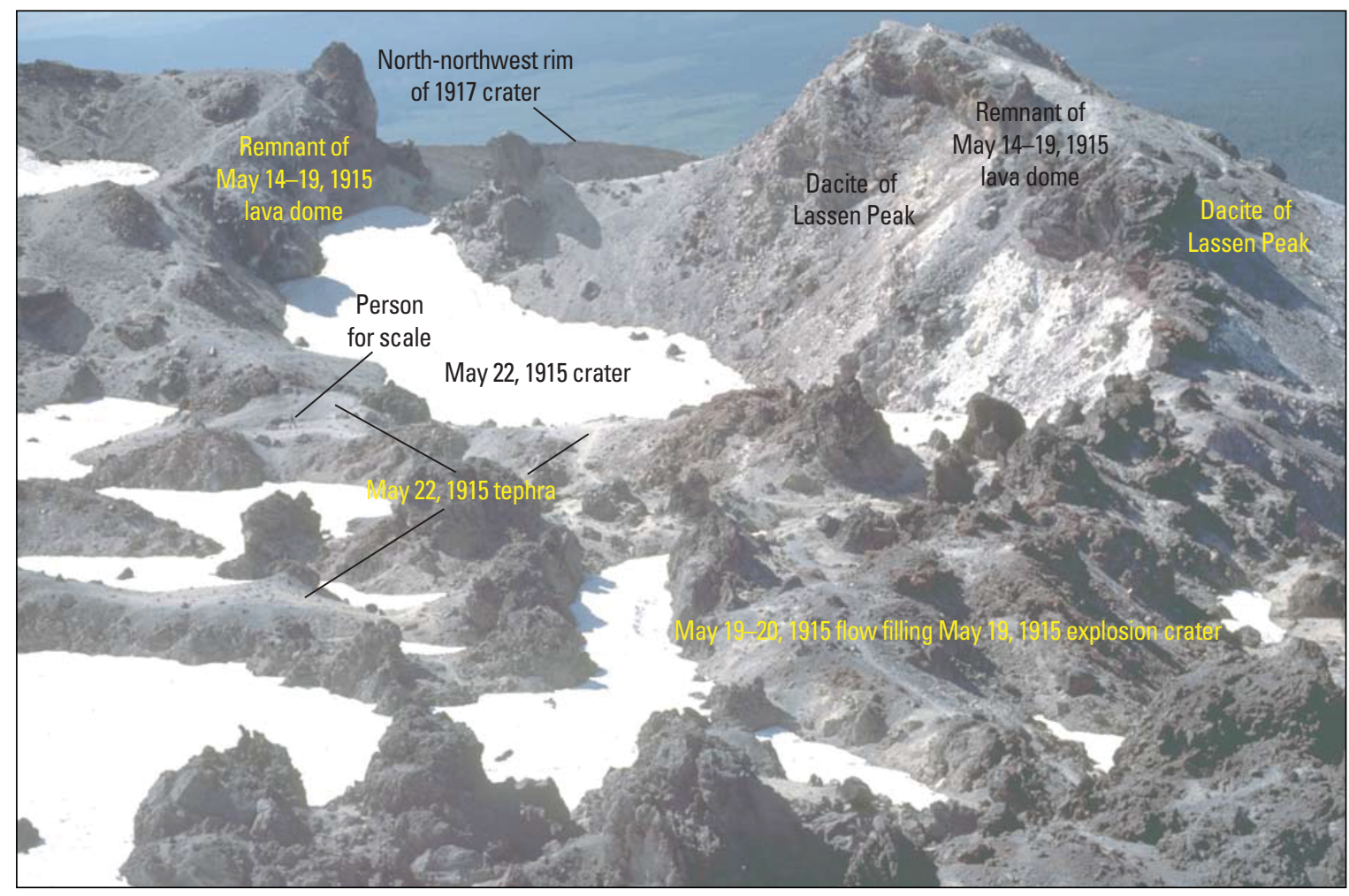

Figure 39. Photograph of the May 22, 1915, crater at the summit of Lassen Peak. View looking north-northwest from the summit of Lassen Peak at deposits from the summit eruption of 1914-1917 (Clynne and others, 2014; Christiansen and others, 2002). Black crags on left and right skyline are remnants of the dacite dome erupted May 14-19, 1915, filling the May 30, 1914May 14, 1915, crater. Craggy area in the foreground to middle ground is the May 19-20, 1915, lava flow that filled the crater created when the lava dome was disrupted on the late evening of May 19, 1915. Crater (now snow-filled) in the middle to upper ground resulted from the pyroclastic eruption of May 22, 1915. Troughs (also snow-filled) in the lava flow resulted from partial slumping of the still-hot lava flow into the May 22 crater. Light-gray patches on the lava flow are tephra from the May 22,1915 , eruption. Gray walls of the May 22 crater are formed of weakly hydrothermally altered dacite of Lassen Peak $(27 \pm 1$ ka) and are partially covered by yellow sulfur deposits related to the 1915 eruption. Rim of crater formed by phreatic eruptions in 1917 visible on the center skyline. Modified from photograph 23 of Muffler and others (2010). 
Figure 40. Low-angle oblique aerial photograph looking southwest at Lassen Peak and the proximal Devastated Area. Terrain with sparse trees marks the paths of avalanche and debris-flow deposits of May 19-20, 1915, and pyroclasticflow and fluid debris-flow deposits of May 22, 1915 (Clynne and others, 2014; Christiansen and others, 2002). Small dark crags just to right of the summit are remnants of the May 19-20, 1915, lava flow. The composite dacite dome of Lassen Peak (27 $\pm 1 \mathrm{ka}$ ) dominates the upper part of the view. Lithic pyroclasticflow deposit from partial collapse of the dome of Lassen Peak is exposed in the canyon of the headwaters of Lost Creek in center of view. Ridges flanking central area are glacial moraines thinly covered by deposits of the 1915 eruption of

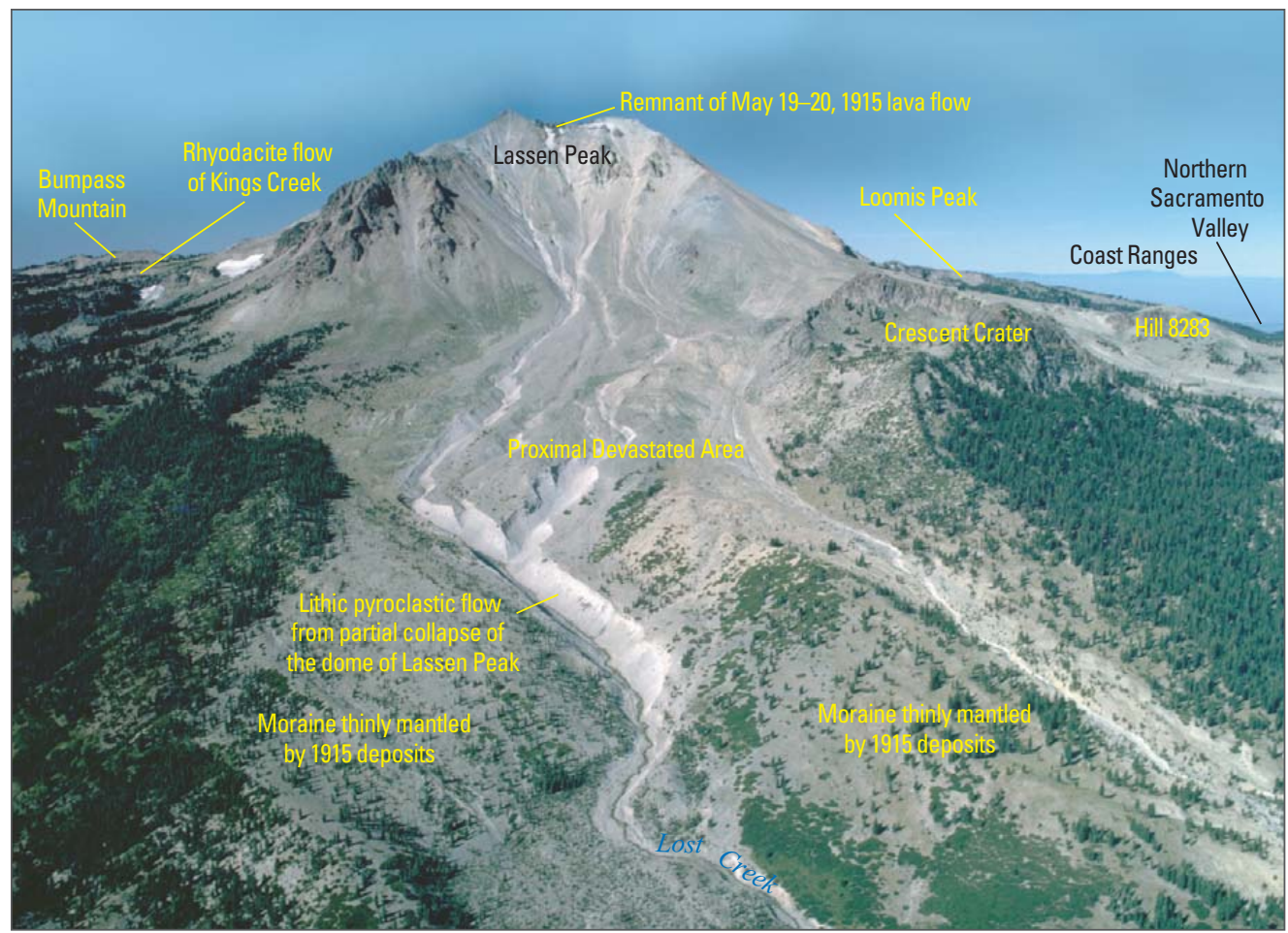
Lassen Peak (Christiansen and others, 2002). A small permanent snowfield is seen on the left lower slope of Lassen Peak. Area to left of the snowfield is the rhyodacite lava flow of Kings Creek ( $35 \pm 1$ ka, part of the Eagle Peak sequence). Dacite domes of Bumpass Mountain (232 \pm 8 ka), Crescent Crater (236 $\pm 1 \mathrm{ka})$, hill $8283(261 \pm 5 \mathrm{ka})$ and rhyodacitic Loomis Peak ( 300 ka) are part of the Bumpass sequence. Photograph 15 of Muffler and others (2010).

Figure 41. Telephoto view northeast from summit of Brokeoff Mountain looking at Lassen Peak (27 $\pm 1 \mathrm{ka}$ ) and the west lobe of the dacite flow of May 19-20, 1915. The rhyodacite of Eagle Peak ( $66 \pm 4 \mathrm{ka}$ ) is part of the Eagle Peak sequence. The dacite of Ski Heil Peak (244 \pm 10 ka, part of the Bumpass sequence) is a dome mantled by tephra from the eruption of Eagle Peak. Ridge in the foreground is composed of the altered andesite of Mount Diller (387 $\pm 10 \mathrm{ka})$, part of the Diller sequence of Brokeoff Volcano. Photograph 21 of Muffler and others (2010).

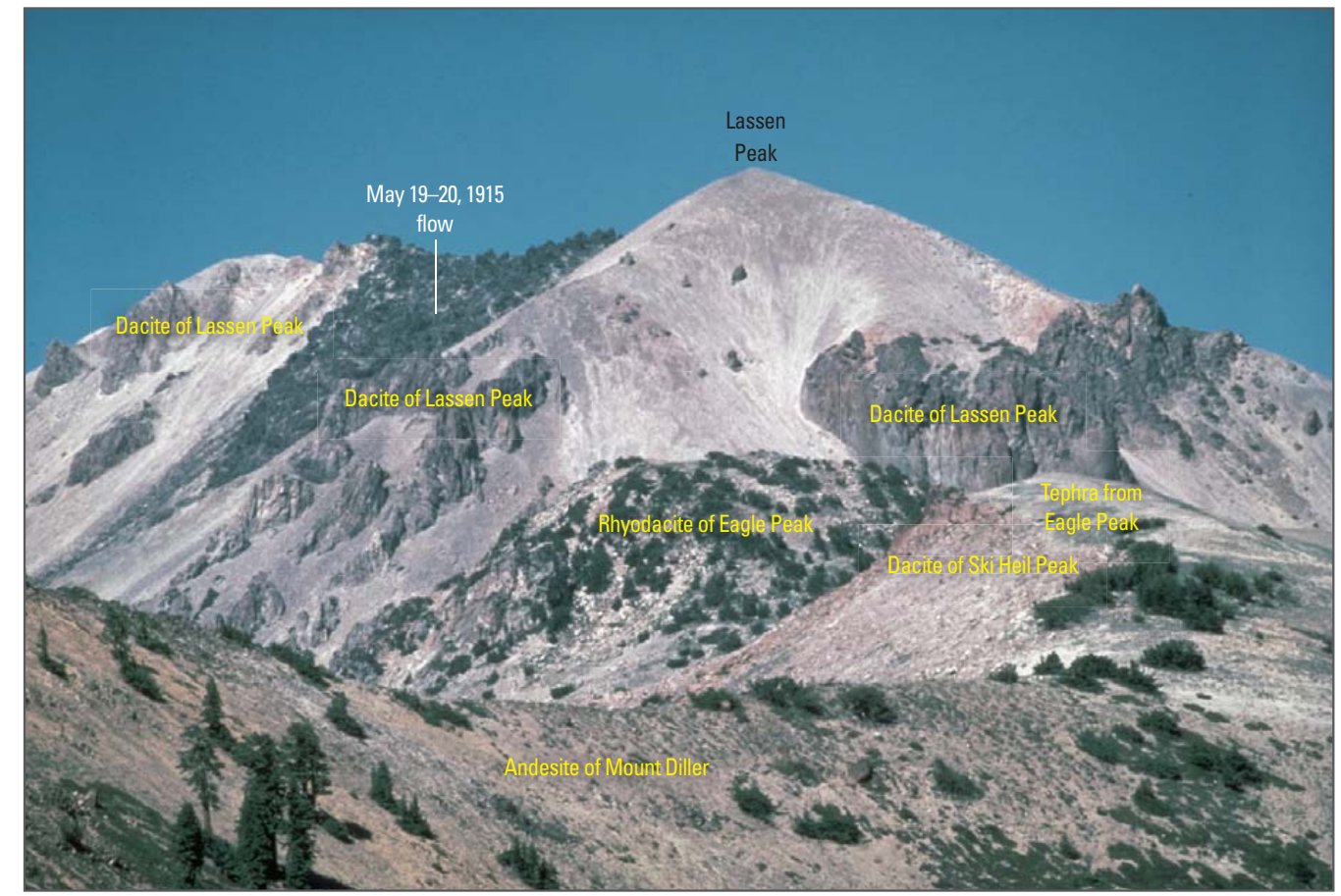



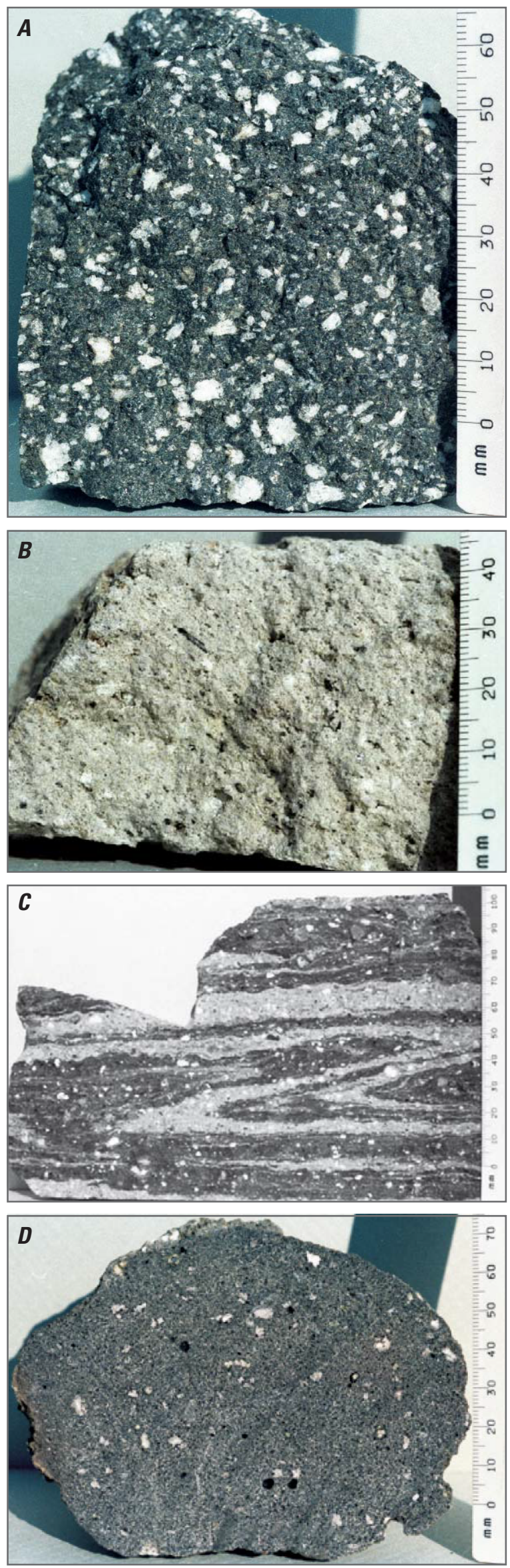

- compositionally banded pumice with dark (60-61 percent $\mathrm{SiO}_{2}$ ) and light bands (64-68 percent $\mathrm{SiO}_{2}$ ) erupted on May 22 (fig. 42C)

- quenched inclusions of andesitic magma (57-60 percent $\mathrm{SiO}_{2}$ ) that are abundant in the black lavas and sparse in the light pumice (fig. $42 D$ ).

The light bands in the banded pumice are generally compositionally equivalent to the black dacite, and the dark bands are compositionally equivalent to the quenched andesitic magma.

The 1915 rock types contain a complex mineral assemblage that indicates mixing between two compositionally distinct magmas: hornblende-biotite rhyodacite (approaching 70 percent $\mathrm{SiO}_{2}$ ) and olivine basaltic andesite ( $\sim 54$ percent $\left.\mathrm{SiO}_{2}\right)$. Each of the 1915 rock types is formed from different proportions of these two magmas through a complex series of interactions (Clynne, 1999). Intrusion of basaltic andesite heated and mobilized rhyodacitic hornblende-biotite crystal mush. Formation and disaggregation of partially crystalline quenched inclusions of the hydridized basaltic andesite played a critical role in forming the array of compositions erupted. It is likely that the intrusion and magma-mixing event that produced these rock types also provoked the eruptions.

As one leaves the Devastated Area parking lot, the cliff ahead and to the right is the rhyolite of Raker Peak (588 $\pm 69 \mathrm{ka})$, a dome of the Rockland caldera complex. The front face of the dome is glaciated, exposing the internal flow structure of the dome. A much younger hybrid andesite volcano, Raker Peak (older Twin Lakes sequence), was built on top of the rhyolite dome at $270 \pm 18$ ka.

For the next 1.8 miles, the road crosses 1915 debris flows, then a recessional moraine of the till of younger glaciation ( $\sim 25-17 \mathrm{ka})$, and then drops down onto the 1915 debris flows again. $\mathbf{1 . 4}$

Figure 42. Photographs of hand specimens of four rock types of very different appearance that were produced over a weeklong period during the May 1915 eruption from the summit of Lassen Peak. Black dacite $(A)$ erupted as the lava dome during approximately May 14-19 and as the lava flows on the late evening to early morning of May 19-20. Light dacite pumice $(B)$ and banded pumice $(C)$ were erupted during the pyroclastic eruption on May 22. The composition of light dacite pumice is similar to that of the light bands in the banded pumice $(C)$ and to that of the black dacite $(A)$. The composition of the dark bands in the banded pumice $(C)$ is similar to that of blobs of andesite found as quenched inclusions $(D)$ in both the black dacite and the light dacite pumice. All four rock types are the products of incomplete mixing between two magmas with contrasting compositions. The mixing process was interrupted by eruption of the partially mixed magmas (Clynne, 1999). 
$51.5 \quad$ Stop 14: Lost Creek sand pit. Lat $40^{\circ} 31.70^{\prime} \mathrm{N}$., long $121^{\circ} 29.11^{\prime} \mathrm{W}$. To the left, 300 feet down a locked service road, the Lost Creek sand pit exposes the two lower pyroclastic flows of Chaos Crags. The sand pit also provides excellent views to the south of Lassen Peak (behind Crescent Crater), several highly glaciated domes of the Bumpass sequence, and four of the six Chaos Crags domes (behind a large lateral moraine of the till of younger glaciation).

The Chaos Crags eruption at $1,103 \pm 13$ years B.P. ( $\sim 850$ C.E.) is the third youngest eruption in Lassen Volcanic National Park. This eruption is typical of the type of volcanic activity to be expected in the Lassen domefield in the future. Detailed geologic mapping (Christiansen and others, 2002) has added significant new detail to the general stratigraphy of the Chaos Crags given by Crandell and others (1974). The Chaos Crags eruptive sequence consists of three pumiceous pyroclastic flows, six domes, and two dome-collapse lithic pyroclastic flows (fig. 43). The volume of the Chaos Crags deposits is approximately $1.2 \mathrm{~km}^{3}$, about 15 percent as pyroclastic flows (not including distal ash).

The initial event of the Chaos Crags eruptive sequence was the eruption of pumice and lithic debris and the formation of a tuff cone. Eruption of the lower and middle pyroclastic flows quickly followed. These were confined to the valleys of Lost and Manzanita
Creeks, where they flowed to a distance of $5 \mathrm{~km}$. The most accessible exposures of these pyroclastic flows are at the Lost Creek sand pit. Whole tree trunks converted to charcoal are often found in the basal zone of the lower pyroclastic flow, indicating that it flowed through and destroyed mature Jeffrey pine forest. The middle pyroclastic flow apparently followed the same path and rarely contains charcoal. At Lost Creek sand pit, tar from distillation of a tree trunk crosses the contact between the two pyroclastic flows and indicates that the middle pyroclastic flow was erupted and emplaced before the lower pyroclastic flow had completely cooled. Although bulldozing in 2008 destroyed the best exposure in the sand pit, there are other locations in the pit where these relations can still be seen.

Shortly after eruption of the lower and middle pyroclastic flows, the vent of the tuff cone was plugged by growth of a small dome, designated "dome A." Dome A was mostly destroyed by a large pyroclastic event that emplaced the widespread upper pyroclastic flow. At $3 \mathrm{~km}$ from the vent, the upper pyroclastic flow became confined to the drainages of Lost Creek and Manzanita Creek, where it flowed to distances of 18 $\mathrm{km}$ and $28 \mathrm{~km}$, respectively. The eruption also built a second tuff cone and deposited a lobe of air-fall pumice that can be traced northeast for $25 \mathrm{mi}(40 \mathrm{~km})$. Near the vent, the upper pyroclastic flow contains blocks of

- Three cold rockfall avalanches from dome $\mathrm{C}$ formed Chaos Jumbles. Radiocarbon age is $278 \pm 28$ years (weighted average of 3 samples)

hiatus of approximately 800 years

- Emplacement of dome $\mathrm{F}$

- Hot dome-collapse lithic pyroclastic avalanche from dome $\mathrm{E}$

- Emplacement of dome $\mathrm{E}$

- Hot dome-collapse lithic pyroclastic flow from dome D

- Emplacement of dome D

- Emplacement of dome C

Possible short hiatus

- Emplacement of dome B

- Explosive disruption of dome A by eruption of the upper pyroclastic flow, accompanied by airfall pumice lobe and formation of a tuff cone. Radiocarbon age is $1,103 \pm 13$ years (weighted average of 16 samples from upper, middle and lower pyroclastic flows)

- Emplacement of dome A

- Eruption of pumiceous lower and middle pyroclastic flows and formation of a tuff cone

- Initial vent opening, air-fall pumice and lithic deposit

Figure 43. Chart giving a summary of events in the formation of Chaos Crags. In stratigraphic order: earliest event at bottom; latest event at top. Adapted from Clynne and others (2002). 
dome $\mathrm{A}$ up to $1 \mathrm{~m}$ in size. No evidence of erosion has been found between the pyroclastic flows, and all three are closely similar in age. A weighted average of 16 uncalibrated ${ }^{14} \mathrm{C}$ ages from all three pyroclastic flows is $1,103 \pm 13$ years B.P. (Clynne and others, 2002).

Subsequent eruption of domes B-F is discussed at Stop 15. 1.1

52.6 Lost Creek. 1915 debris flows overlie pyroclastic flows from the Chaos Crags eruptions of $1,103 \pm 13$ years B.P. ( $\sim 850$ C.E.). For the next 2 miles, the road passes through till of younger glaciation $(\sim 25-17 \mathrm{ka})$ that is composed primarily of dacite boulders from Lassen Peak. 2.1

54.7 To the left are the Sunflower Flat domes, a group of eight $41 \pm 1 \mathrm{ka}$, hornblende-biotite rhyodacite domes that were preceded by eruption of air-fall pumice and a pyroclastic flow (the flat over which the road passes). Mature forest obscures the relatively youthful, unglaciated morphology of the domes. $\mathbf{0 . 6}$

55.3 On the right is the bouldery block-lava flow surface of the two-pyroxene andesite of Table Mountain, a shield volcano ( $\sim 700 \mathrm{ka})$ related to regional volcanism outside the Lassen Volcanic Center. 1.4

56.7 Talus on left is from the northernmost of the Sunflower Flat rhyodacite domes; the road is once again on pyroclastic flow of Sunflower Flat. $\mathbf{0 . 8}$

\subsection{Edge of Chaos Jumbles. 0.6}

58.1 Stop 15: Chaos Crags, Chaos Jumbles, and quenched mafic inclusions. Lat $40^{\circ} 32.50^{\prime} \mathrm{N}$., long $121^{\circ} 30.58^{\prime} \mathrm{W}$. The initial events of the Chaos Crags eruptive sequence $(1,103 \pm 13$ years B.P.; $\sim 850$ C.E. $)$ were discussed at the Lost Creek sand pit (mile 51.5). Subsequent to eruption of the upper pyroclastic flow, a series of domes was emplaced, probably in rapid succession (fig. 43). The domes are designated in chronological order, $\mathrm{B}$ through F. Domes D and E had hot collapse events that produced short lithic pyroclastic flows. Approximately 350 years ago in the mid 1600 s C.E. $(278 \pm 28$ years B.P., referenced to 1950 C.E.), the Chaos Jumbles were formed when dome $\mathrm{C}$ partially collapsed in three cold rockfall avalanches (fig. 44).

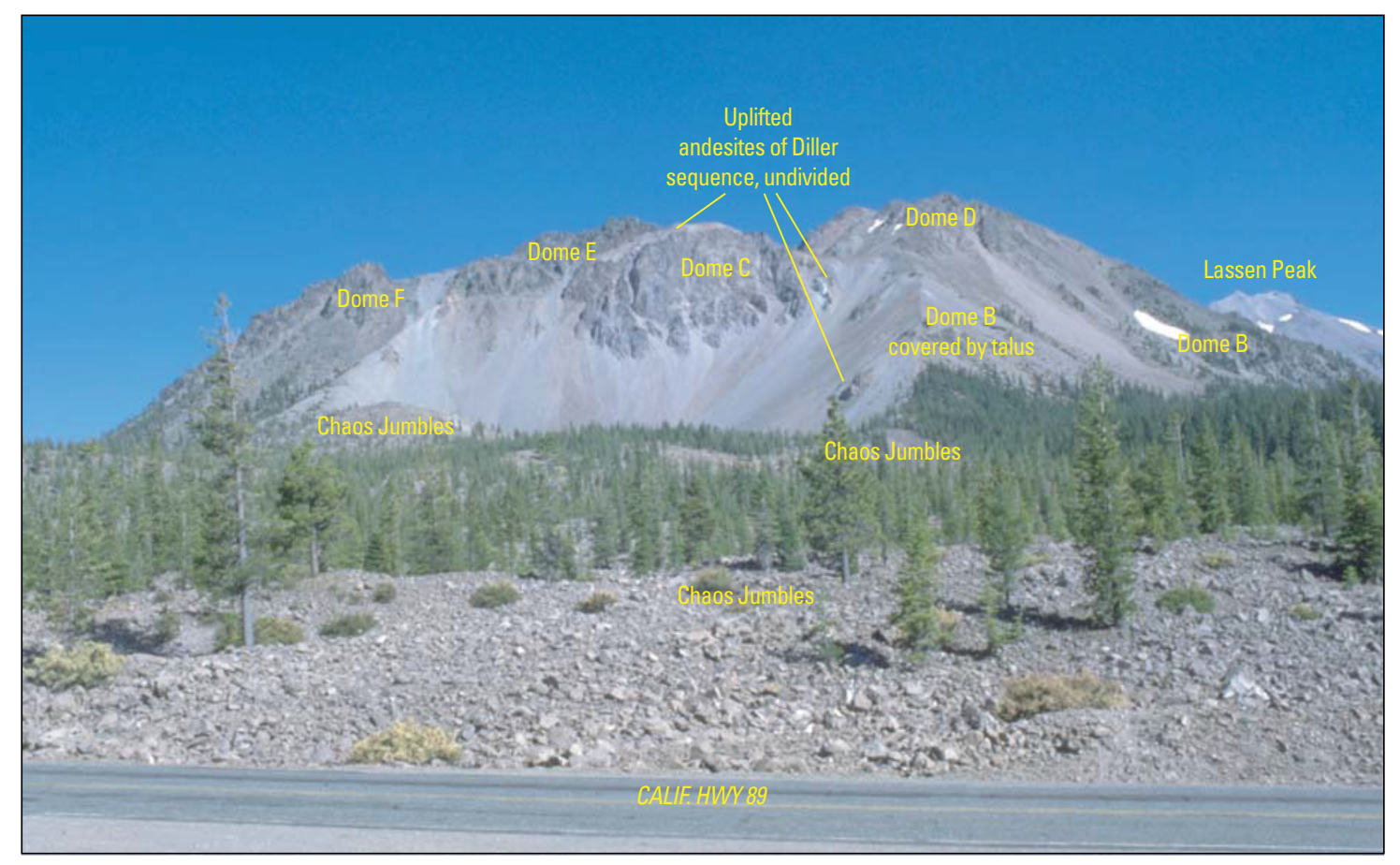

Figure 44. Photograph of Chaos Crags and Chaos Jumbles looking southeast from Calif. Hwy 89. Hummocky surface of the avalanche deposits of Chaos Jumbles (278 \pm 28 years B.P.; mid 1600 s C.E.) is in the foreground and middle ground. The oval-shaped massive rock cliff (dome $C$ of Chaos Crags) in the center of the view is the source of the Chaos Jumbles deposits. The highest peak is dome $D$, and the high ground above and to the left of dome $C$ is dome $E$. Small peak on the left is dome $F$. The sparsely tree-covered area (below the large snow bank) on the right flank of dome $D$ is dome $B$, which extends beneath talus from younger domes to the sharp talus-covered ridge beneath dome D. Lassen Peak $(27 \pm 1 \mathrm{ka})$ is on the extreme right at the skyline. Forested area on right below the domes is underlain by young glacial moraines. Light-colored smooth surface above dome $C$ and outcrops to right of dome $C$ are andesite of the Diller sequence (part of Brokeoff Volcano) uplifted during emplacement of the dome. Photograph 29 of Muffler and others (2010). 
All of the Chaos Crags units are porphyritic hornblende-biotite rhyodacites or dacites that contain 67-70 percent $\mathrm{SiO}_{2}$ (fig. 45). Dense rocks of Chaos Crags contain about 40 volume percent crystals of plagioclase, biotite, hornblende, quartz, and xenocrystic olivine and augite. Two lithologic groups are recognized: group 1 comprises the three pyroclastic flows plus domes $\mathrm{A}$ and $\mathrm{B}$. This group has a narrow range of composition (69-70 percent $\mathrm{SiO}_{2}$ ), contains sparse quenched inclusions (see below), and displays little evidence of disaggregated inclusions. Group 2 comprises domes $\mathrm{C}-\mathrm{F}$ and contains 67-69 percent $\mathrm{SiO}_{2}$, abundant inclusions (sometimes approaching 20 percent of the rock), and abundant evidence of disaggregated inclusions. The compositional variation in the Chaos Crags is due to disaggregation of inclusions (Tepley and others, 1999).

Quenched inclusions ("blobs") of mafic magma occur in all the Chaos Crags rocks but are especially abundant in the later domes. The inclusions form when blobs of hot mafic magma are injected into cooler silicic magma and are thus chilled (fig. 46). The inclusions display a variety of textures from aphyric (with a relatively coarse-grained groundmass) to porphyritic (with a relatively fine-grained groundmass). The phenocrysts in the porphyritic variety are resorbed felsic crystals derived from mixing with the silicic host magma at the time of inclusion formation. Where both aphyric and porphyritic types occur in the same inclusion, the finer-grained porphyritic material concentrically surrounds the coarser-grained aphyric material. Most quenched inclusions also contain olivine, calcic plagioclase, and augite phenocrysts inherited from their basaltic parent. The magma-mixing events associated with the intrusion of basalt and the formation and disaggregation of quenched inclusions play an important role in maintaining the magmatic system at the Lassen Volcanic Center by adding heat and mass to mostly crystalline magma, and in some cases these events provoked eruptions (Guffanti and others, 1996; Clynne, 1999; Klemetti and Clynne, 2014).
Figure 45. Graph of $\mathrm{SiO}_{2}$ content versus $\mathrm{K}_{2} \mathrm{O}$ content for the quenched mafic inclusions and host rocks in Chaos Crags. The composition of the intruded basalt magma was approximately 52 percent $\mathrm{SiO}_{2}$ and 0.7 percent $\mathrm{K}_{2} \mathrm{O}$, and the composition of the resident rhyodacite magma was approximately 70 percent $\mathrm{SiO}_{2}$ and 2.8 percent $\mathrm{K}_{2} \mathrm{O}$. The basalt magma was variably hybridized by mixing with rhyodacite before quenching to form inclusions. Convection of the host rhyodacite magma caused disaggregation of the inclusions (Clynne, 1999; Tepley and others, 1999), thus also hybridizing the rhyodacite. Inclusions in group 1 (the pyroclastic flows plus domes $A$ and $B)$ have a relatively narrow range of composition, from weakly hybridized to about 58 percent $\mathrm{SiO}_{2^{\prime}}$ and the units of group 1 contain little evidence for inclusion disaggregation. Inclusions in group 2 (domes $\mathrm{C}-\mathrm{F}$ ) have a wider

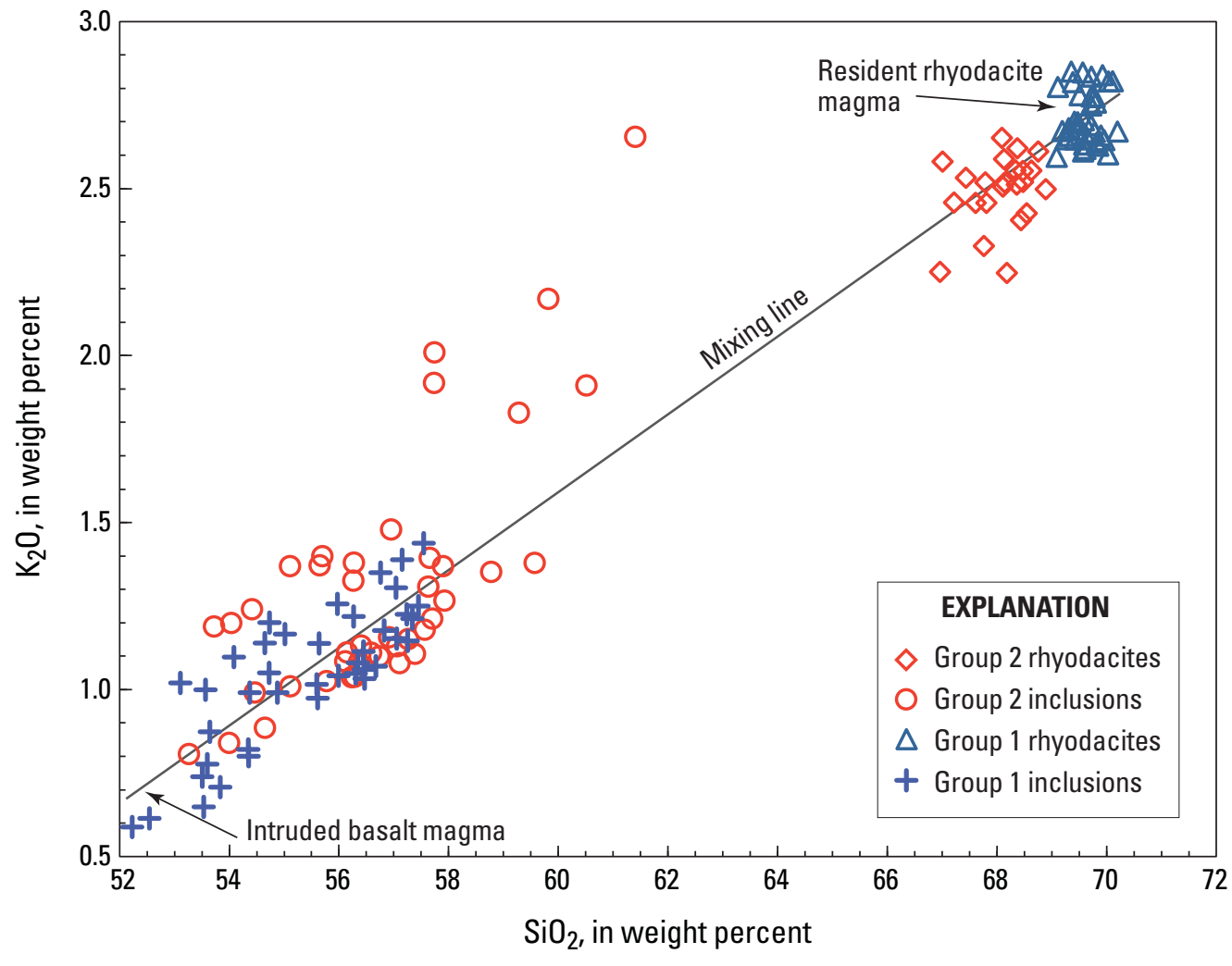
range of compositions (to nearly 60 percent $\mathrm{SiO}_{2}$ ), and disaggregation of inclusions in domes of group 2 is conspicuous. Thus, interaction between the basalt and host magma increased as the Chaos Crags eruption progressed. The position of the mixing line on this figure is approximate, especially at the mafic end, because the inclusions are often autofractionated by gas filter pressing as they vesiculate (Bacon, 1986). Crystallization of an inclusion with a quenched margin approximates a closed system, and when the residual magma reaches vapor saturation it vesiculates. Residual liquid is forced toward the inclusion margins and produces liquid-enriched compositions. The remaining core of the inclusion is the corresponding liquiddepleted composition. Thus, the chemical analysis of a sample from an inclusion may not be precisely representative of two-component mixing, resulting in the expanded array of compositions surrounding the mixing line. A few inclusions in group 2 are anomalously enriched in $\mathrm{K}_{2} \mathrm{O}$ and $\mathrm{SiO}_{2}$ and thus plot significantly above the mixing line of this figure (Scruggs and others, 2014). These inclusions also have more radiogenic ${ }^{87} \mathrm{~S} /{ }^{86} \mathrm{Sr}$ than the main array of the inclusions (Tepley and others, 1999). These chemically anomalous inclusions must have been contaminated by an additional felsic component, perhaps Sierran basement. 
Figure 46. Photograph of quenched mafic inclusion in dacite/rhyodacite of Chaos Crags. This inclusion shows some of the features that can be observed in the suite of inclusions from Chaos Crags. The inclusion has a fine-grained quenched rim with a convolute boundary against the host, whereas its core is more coarsely crystalline. Fingers of the inclusion demonstrate how the host silicic magma is pinched off and crystals are "captured" by the mafic inclusion. This inclusion has relatively few host crystals, but a few can be seen even in the core of the inclusion. Brown spots at the lower left are lichen.

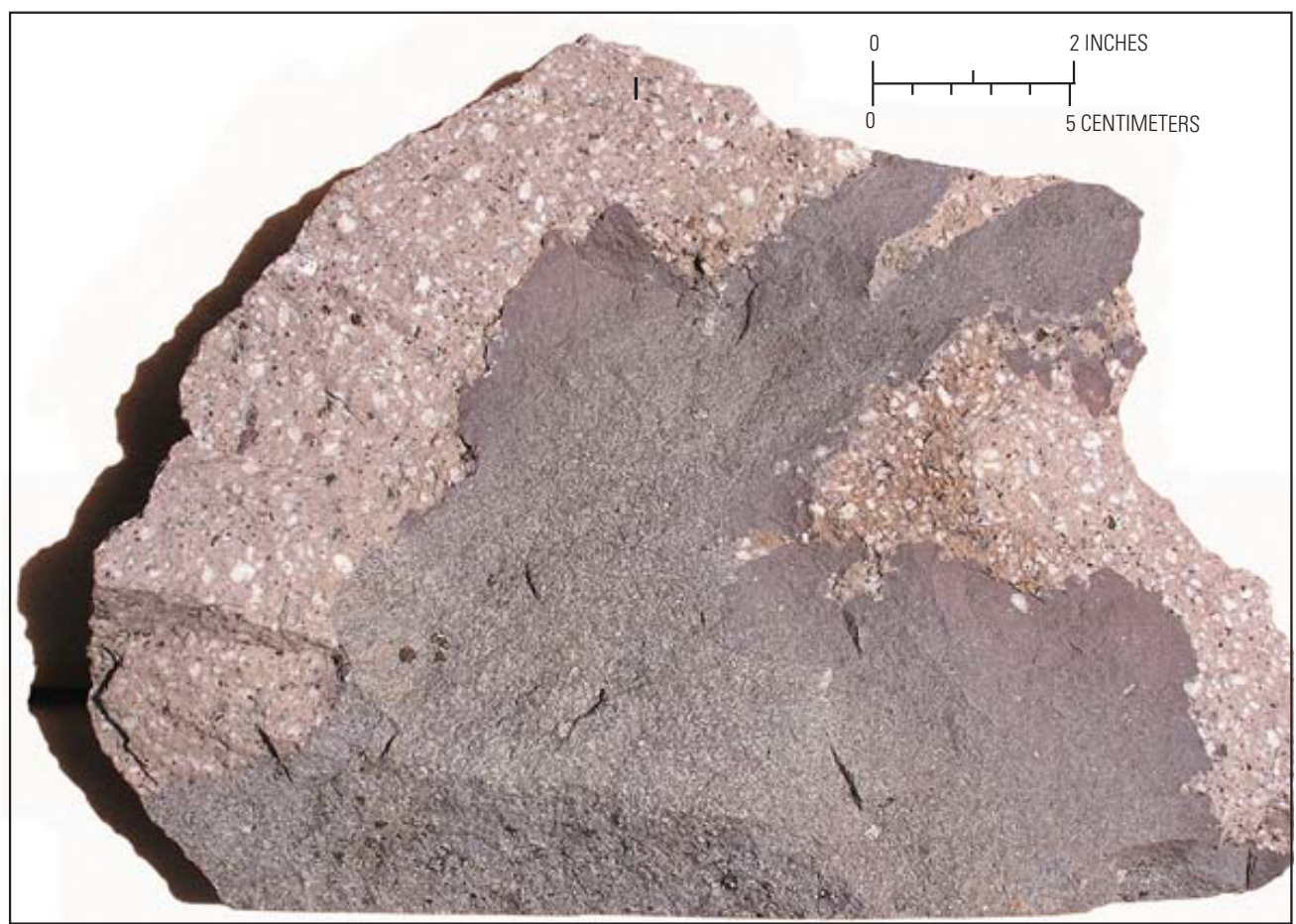

The Chaos Jumbles comprise three separate rockfall avalanches covering $2.5 \mathrm{mi}^{2}\left(6.8 \mathrm{~km}^{2}\right)$ that can be distinguished on the basis of flow margins and distribution of block sizes. The deposits consist of a monolithologic breccia of Chaos Crags dacite blocks in a matrix of pulverized dacite. The deposits have steep distal and lateral margins $1-5 \mathrm{~m}$ in height. The first rockfall avalanche was the largest and traveled $\sim 3 \mathrm{mi}$ $(\sim 5 \mathrm{~km})$ with a vertical drop of $2,200 \mathrm{ft}(670 \mathrm{~m})$ from the breakaway scar on dome $\mathrm{C}$ of Chaos Crags. The other avalanches were successively smaller and shorter, but thicker. The avalanche paths were controlled by existing topography. The initial direction of each avalanche was west-northwest towards Table Mountain. The first avalanche deposit rode up nearly $400 \mathrm{ft}(120 \mathrm{~m})$ onto Table Mountain before being deflected to the west. Groovelike linear features on the surface of the deposit were interpreted by Eppler and others (1987) to be strikeslip faults caused by compression during flow as the avalanche was deflected by Table Mountain. Regularly spaced surface ridges are oriented perpendicular (transverse) to the direction of flow. The avalanches apparently were emplaced as material of high yieldstrength, capable of deforming and shearing, rather than as a plug of nondeforming material being carried on a deforming basal layer (Eppler and others, 1987).

Steep-sided volcanic domes are clearly unstable and prone to collapse, but the trigger for the Chaos Jumbles collapse is unknown. A number of mechanisms have been proposed, including an explosion at the base of dome C (Williams, 1932) and renewed volcanic activity on dome $\mathrm{D}$, which was reported by the Whitney Survey to have been steaming in 1857 (Brewer, 1930). However, there is no evidence to support either of these ideas, and the most likely explanation is triggering by a large earthquake, possibly on the Hat Creek Fault 20 mi to the north. $\mathbf{1 . 7}$

59.8 To the left across Manzanita Lake can be seen Loomis Peak, a rhyodacite lava flow ( $\sim 300 \mathrm{ka})$ of the Bumpass sequence. To the east is the $66 \pm 4$ ka rhyodacite dome of Eagle Peak. To the right, Reflection Lake is a closed depression on the Chaos Jumbles rockfall avalanche. The oldest of the three Chaos Jumbles rockfall avalanches crossed and dammed Manzanita Creek to form Manzanita Lake. Radiocarbon ages of wood samples from trees drowned in the lake that formed behind the dam (Clynne and others, 2002) are consistent with cores taken from trees on the oldest avalanche (Heath, 1959) and confirm the conclusion of Crandell and others (1974) that all three avalanches occurred in quick succession about 350 years ago. 0.7

60.5 T-junction with Calif. Hwy 44. To the left, Calif. Hwy 44 leads west to Redding (see Section H of Muffler and Clynne, 2010). Turn right on Calif. Hwy 44 and 89 north towards Old Station. Roadcuts are in rhyodacite pyroclastic-flow deposits from Eagle Peak (66 $\pm 4 \mathrm{ka}$ ). Pass out of the Lassen Volcanic Center and onto rocks related to regional volcanism. $\mathbf{1 . 3}$

61.8 Noble Pass. To the left is Eskimo Hill ( $\sim 75 \mathrm{ka})$, which marks the crest of the Cascade Range in this area. Scoria 
cones ahead and to the left are vents for basaltic andesite and andesite of Red Lake Mountain (also $\sim 75 \mathrm{ka}$ ). For the next 6 miles, the road lies on slightly older flows from Red Mountain. The northern flank of Table Mountain $(\sim 700 \mathrm{ka})$ is on the right. $\mathbf{4 . 6}$

66.4 Lat $40^{\circ} 36.41^{\prime} \mathrm{N}$., long $121^{\circ} 31.33^{\prime} \mathrm{W}$. Boulders on the flat to the right were deposited by the May 19-20, 1915, debris flow from Lassen Peak. The May 22 debris flow also left a thin deposit in this area, but that debris flow was too fluid to carry large boulders this far. The debris flows lie on the upper pyroclastic flow from Chaos Crags (1,103 \pm 13 years B.P.; $\sim 850$ C.E. $). \mathbf{1 . 0}$

67.4 Lat $40^{\circ} 36.82^{\prime} \mathrm{N}$., long $121^{\circ} 30.36^{\prime} \mathrm{W}$. To left is the block-lava flow front of a 35-ka augite-olivine andesite from Bear Wallow Butte, which is the southernmost of a group of 10 scoria cones and lava flows of the Tumble Buttes chain. The youngest of these, the andesite of Devils Rock Garden, may be Holocene (less than $11 \mathrm{ka}$ ), and most of the units are less than $\sim 50 \mathrm{ka}$. This $15-\mathrm{km}-$ long line of scoria cones and lava flows is oriented at azimuth $345^{\circ}$, parallel to regional faults, and illustrates fault control of the patterns of vents of the regional volcanism. The most likely future volcanic event in the Lassen area is eruption of mafic magma leading to the formation of a scoria cone and lava flows like those in the Tumble Buttes chain (Clynne and others, 2012). 0.9

68.3 The flat plateau at 12:00 is the Hat Creek Rim, the upthrown block of a normal fault bounding the Hat Creek Valley on the east (See miles 48.2 and 64.4 of day 3). The rounded shield volcano on the skyline is Blacks Mountain, a nearly aphyric olivine andesite $(2,403 \pm 19 \mathrm{ka})$. Good views of Lassen Peak and Chaos Crags to the south. $\mathbf{0 . 7}$

69.0 Lat $40^{\circ} 37.52^{\prime} \mathrm{N}$., long $121^{\circ} 28.77^{\prime} \mathrm{W}$. On the right is a U.S. Forest Service exhibit entitled "Panoramic Point" that once had an excellent view of Lassen Peak to the south. Unfortunately, uncontrolled growth of the forest since it was planted in 1961 has (as of 2016) completely obscured the view. Restrooms and picnic tables are available. $\mathbf{1 . 4}$

70.4 Lat $40^{\circ} 38.63^{\prime}$ N., long $121^{\circ} 28.17^{\prime} \mathrm{W}$. Big Spring, the source of much of the water in Hat Creek, discharges along a prominent fault uplifting the tholeiitic basalt of Twin Bridges (780-730 ka), which is exposed in roadcuts for the next 0.7 mile. $\mathbf{0 . 7}$

71.1 Old Station Post Office is built on glacial outwash of the younger glaciation $(\sim 25-17 \mathrm{ka})$, which contains cobbles derived from the dacite of Lassen Peak. 1.5
Stop 16: Vents of Hat Creek Basalt. Lat $40^{\circ} 40.15^{\prime} \mathrm{N}$., long $121^{\circ} 26.61^{\prime} \mathrm{W}$. Parking area on the right for the trail to the vent area of the Hat Creek Basalt, a $24 \pm 6 \mathrm{ka}$ (Turrin and others, 2007) low-K olivine tholeiitic (LKOT) basalt lava flow that is characteristic of volcanism in the Basin and Range Province of the western United States. This type of lava erupts from a fissure and builds a low edifice capped by spatter cones. The lava forms an extensive but thin sheet that is distributed by a system of lava tubes. The Hat Creek Basalt flowed for 20 miles to the north in Hat Creek Valley (Anderson, 1940). The flow covered $\sim 100 \mathrm{~km}^{2}$, is as thick as $50 \mathrm{~m}$ along the axis of the Hat Creek Graben, and has a volume of $\sim 2.5 \mathrm{~km}^{3}$. The rock has sparse olivine phenocrysts in a completely crystalline (holocrystalline) groundmass, often diktytaxitic. For details of petrology and geochemistry of the Hat Creek Basalt see Anderson (1971), Anderson and others, (1982), and Anderson and Gottfried (1971).

A 1.5-mile hike (round trip) along this trail takes one to the vent area for the Hat Creek Basalt. The trail begins in an old calc-alkaline lava flow and then winds along the margin of the Hat Creek Basalt before ascending onto the flow. The flow locally displays a pāhoehoe surface and is broken by tumuli. White hornblende-biotite pumice lapilli and ash scattered on the ground are from the eruption of Chaos Crags at $1,103 \pm 13$ years B.P.; $\sim 850$ C.E.) The vent area is a 1.75-mile-long rampart dotted with small spatter cones. 1.6

74.2 Junction of Calif. Hwys 89 and 44. Continue straight on Calif. Hwy 89 north down the Hat Creek Valley towards Burney. For the next 17 miles, the field-trip route duplicates part of day 3, miles 35.8 to 63.0 , but in reverse and excluding the loop to Stop 3. $\mathbf{0 . 3}$

74.5 Turnoff to right leads to Subway Cave, a U.S. Forest Service exhibit that allows exploration of part of a lava tube in the Hat Creek Basalt. For the next 17 miles, Calif. Hwy 89 lies primarily on the Hat Creek Basalt.

To the left is the rugged edifice of the andesite of Sugarloaf Peak (46 \pm 7 ka; Turrin and others, 2007), the most prominent volcano of the Sugarloaf chain. Units of the Sugarloaf chain bury faults on the west boundary of Hat Creek Valley. 3.6

78.1 Calif. Hwy 89 crosses Hat Creek and passes from the Hat Creek Basalt onto an outlier of the older andesitic rocks that form the west rim of the Hat Creek Valley. $\mathbf{1 . 2}$

79.3 Rocks to the left of the road for the next 1.1 miles are units of the Sugarloaf chain. 1.6 returns to the Hat Creek Basalt. In the right distance is 
the valley of Lost Creek, which cuts a prominent canyon through the Hat Creek Rim. The water in Lost Creek is derived by underground flow from Butte Creek (east of the Hat Creek Rim) and ultimately from the eastern part of Lassen Volcanic National Park.

The ridge to the left (west) of the highway consists of older andesitic rocks and separates the Hat Creek Basalt from a north-trending belt of quite young volcanic rocks, as yet undated. $\mathbf{4 . 2}$

85.1 On the right, the south entrance to Doty Road leads to Stop 2 of Day 3 (the "Active Scarp" of the Hat Creek Fault). 1.7

86.8 On right is the north entrance to the loop of Doty Road. Calif. Hwy 89 is on the Hat Creek Basalt, but steep hills just to the left (west) of the highway are much older (early to middle Pleistocene?) andesites. The prominent, rugged volcanic edifice to the northeast is the basaltic andesite of Cinder Butte $\left({ }^{40} \mathrm{Ar}{ }^{\beta 9} \mathrm{Ar}\right.$ age of $38 \pm 7 \mathrm{ka}$; Turrin and others, 2007). $\mathbf{1 . 6}$

88.4 Highway crosses Hat Creek. $\mathbf{1 . 6}$

90.0 Highway crosses Hat Creek and passes along the contact between alluvium to the right and the toe of the late Pleistocene basalt of Doyles Corner, one of the units in the belt of the young lava flows that lies west of the early to middle Pleistocene(?) andesites that form the west rim of Hat Creek Valley. The vent for the basalt of Doyles Corner is 2 miles to the southwest. 0.8

90.8 Doyles Corner. Road 7R01 (Cassel Road) to the right leads along Hat Creek to the town of Cassel. $\mathbf{0 . 3}$

91.1 Highway passes from alluvium across a fault scarp onto the tholeiitic basalt of Rocky Ledge (197 \pm 8 ka). 0.2

91.3 Intersection on left with a gravel road (Mountain View Road) that leads south for a mile and then west five miles to the town of Burney. Calif. Hwy 89 continues northwest on the flat upper surface of the tholeiitic basalt of Rocky Ledge. $\mathbf{2 . 3}$

93.6 The mountain to the right, Brush Mountain, is a complex, faulted, calc-alkaline volcano probably $2.5 \mathrm{Ma}$ in age. Surprisingly, the summit of the mountain consists of a much younger basalt plug and basaltic andesite cinder cone, perhaps $\sim 50 \mathrm{ka}$ in age. $\mathbf{2 . 0}$

95.6 Four-way stop at the busy, major highway intersection with Calif. Hwy 299. Calif. Hwy 89 continues straight across the tholeiitic basalt of Rocky Ledge to McArthurBurney Falls Memorial State Park (6 miles), across the Pit River, and eventually to Interstate 5 at the city of
Mount Shasta. Calif. Hwy 299 to the right leads northeast across the Pit River to Fall River Mills and eventually to Alturas.

Turn left on Calif. Hwy 299 towards Burney. 0.7

96.3 Calif. Hwy 299 crosses the prominent scarp of the Rocky Ledge Fault, which displaces the tholeiitic basalt of Rocky Ledge $\sim 100$ feet vertically. The northeast end of the roadcut consists of the tholeiitic basalt of Rocky Ledge, whereas the southwest part of the roadcut consists of much older underlying calc-alkaline basalt $\left(2,740 \pm 110 \mathrm{ka} ;{ }^{40} \mathrm{Ar} /{ }^{39} \mathrm{Ar}\right.$ determination by P.R. Renne). 0.8

97.1 Pass through community of Johnson Park. 2.4

99.5 Black Ranch Road (7P200) to the right as one passes into the town of Burney. At 10:30 is Burney Mountain (280 6 ka; M.A. Lanphere, written commun., 1998). The summit of this large dome complex is at an elevation of 7,863 ft (2,397 m), nearly 4,800 ft (1,463 m) above the town of Burney. At the summit, dome 6 rises above the much larger dome 5 . The lower flanks of the mountain are dome 2. 0.7

100.2 Prominent stop light in the town of Burney at the intersection of Calif. Hwy 299 with Mountain View Road on the left. End of Day 4 road log.

\section{Day 3 (Burney to Pole Creek)}

Prominent stop light in the town of Burney at the intersection of Calif. Hwy 299 with Mountain View Road on the left. Drive north on Calif. Hwy 299. Highway is on the upper surface of tholeiitic basalt of Rocky Ledge. 0.7

Black Ranch Road (7P200) to the left (west). 2.4

3.1 Pass through community of Johnson Park. 0.5

Lat $40^{\circ} 55.56^{\prime} \mathrm{N}$., long $121^{\circ} 37.16^{\prime} \mathrm{W}$. Rocks exposed at the southwest end of the large roadcut (fig. 47) comprise a kipuka of calc-alkaline basalt $(2,740 \pm 110 \mathrm{ka}$; ${ }^{40} \mathrm{Ar} /{ }^{39} \mathrm{Ar}$ determination by P.R. Renne). The kipuka is overlain in the northeast part of the roadcut by the tholeiitic basalt of Rocky Ledge (197 \pm 8 ka; weighted average of three ${ }^{40} \mathrm{Ar}{ }^{39} \mathrm{Ar}$ determinations by A.T. Calvert). 0.3 .

Calif. Hwy 299 crosses the prominent scarp of the Rocky Ledge Fault, which displaces the tholeiitic basalt of Rocky Ledge $\sim 100$ feet vertically. $\mathbf{0 . 7}$ Hwys 89 and 299. Straight ahead, Calif. Hwy 299 leads 


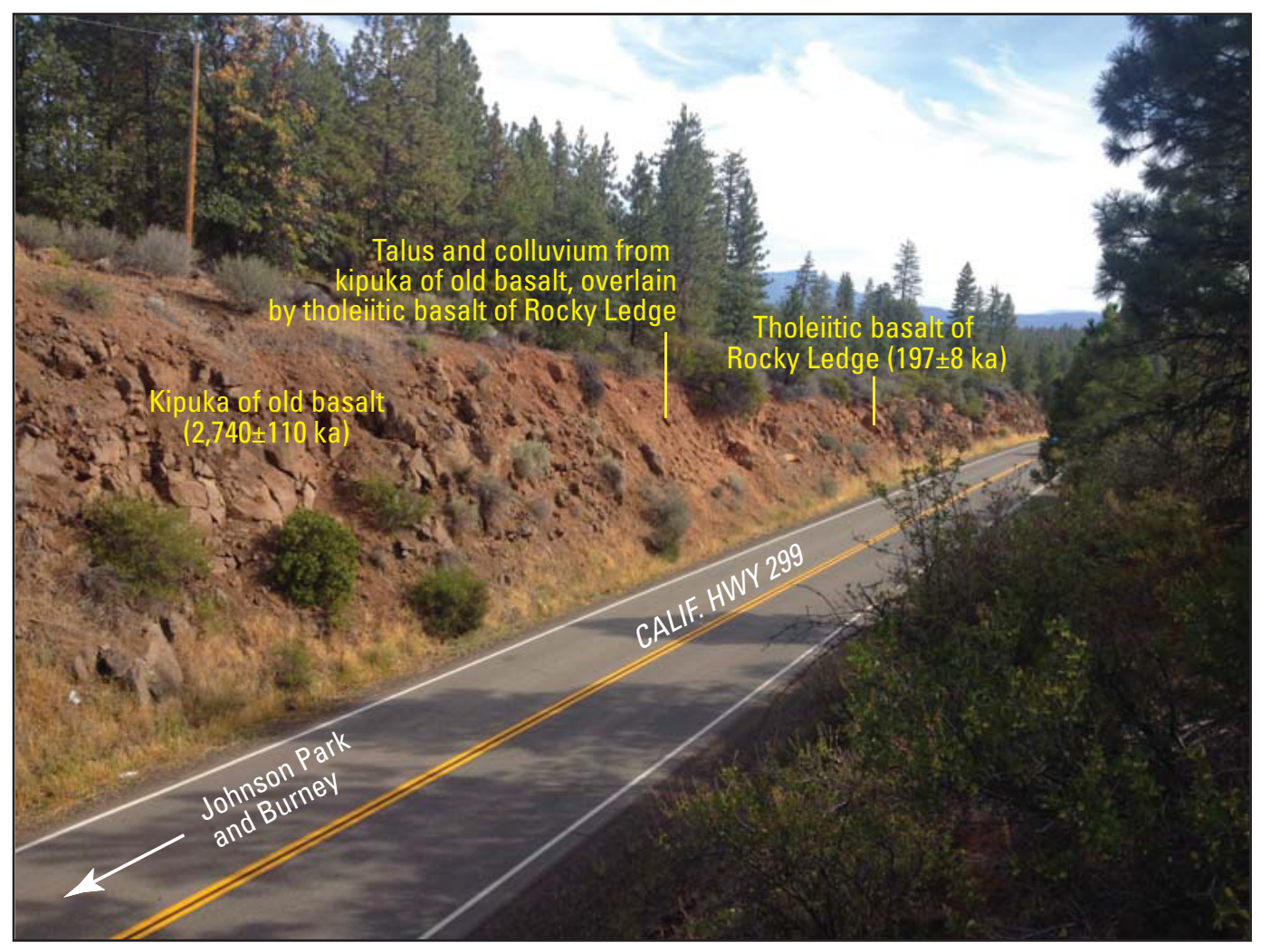

Figure 47. Photograph looking north across roadcut along Calif. Hwy 2990.5 mile northeast of Johnson Park.

northeast across the tholeiitic basalt of Rocky Ledge to the Pit River, Fall River Mills, and eventually reaches to Alturas. Calif. Hwy 89 to the right goes south to Old Station. Turn left on Calif. Hwy 89. For the next 8 miles, Calif. Hwy 89 is on the upper surface of the tholeiitic basalt of Rocky Ledge. $\mathbf{0 . 9}$

5.5 Calif. Hwy 89 crosses right of way for the PG\&E gas pipeline. 1.4

6.9 Old railroad grade that provides excellent exposures of the tholeiitic basalt of Rocky Ledge. $\mathbf{0 . 8}$

7.7 To the right (east) across the grassy area is a prominent normal fault (up to the east) exposing several flow units of the tholeiitic basalt of Rocky Ledge. $\mathbf{0 . 7}$

8.4 To the left is Clark Creek Road, which leads $3 \mathrm{mi}$ northwest to the PG\&E Pit \#3 dam, which impounds Lake Britton. 2.0

10.4 Entrance on left to McArthur-Burney Falls Memorial State Park. A short walk from the parking lot leads one to Burney Falls (see fig. 14). 1.2
11.6 On the right are exposures of a small littoral cone, probably formed at the distal end of the tholeiite of Rocky Ledge where it entered a lake. $\mathbf{0 . 2}$

11.8 On the right is a large roadcut of diatomite that underlies the tholeiitic basalt of Rocky Ledge, followed immediately to the east by a bold outcrop of older ( $>2 \mathrm{Ma}$ ?) calc-alkaline andesite.

Cliffs high above to the right of the highway are the tholeiitic basalt of Rocky Ledge, and an exposure $1.1 \mathrm{mi}$ to the southeast displays excellent pillow breccia at the base of the flow. This flow vented $>12 \mathrm{mi}(19 \mathrm{~km})$ to the south and flowed north to the Pit River. Flows of tholeiitic basalt both from the south and from the north terminate along the course of the modern Pit River, indicating that this area has been a topographic low for at least a million years. $\mathbf{0 . 3}$

12.1 Bridge over Lake Britton, a lake impounded behind a PG\&E-owned dam $2.8 \mathrm{mi}(4.5 \mathrm{~km})$ to the west. The lake is along the course of the Pit River, the major tributary of the Sacramento River. The outcrops just south of the bridge are older calc-alkaline volcanic rock. The bridge abutments and the railroad grade just to the northwest, however, are in diatomite. Drill holes 
show that the diatomite here was deposited in rugged canyon topography cut into the older calc-alkaline volcanic rocks. $\mathbf{1 . 2}$

13.3 Stop 16. Roadcut exposes white diatomite overlain by the tholeiitic basalt of Pole Creek. (Same as Stop 1.) At the base of the basalt are excellent pillows of basalt pushing into the underlying diatomite, showing that the diatomite was wet at the time of basalt emplacement. Overlying the pillows s pillow breccia and then subaerial basalt at the top of the roadcut. The age of the tholeiitic basalt of Pole Creek ( $974 \pm 12 \mathrm{ka})$ puts an an upper limit on the age of the diatomite at this site. $\mathbf{0 . 1}$

13.4 Road to right (USFS Road 37N03) leads east across the tholeiitic basalt of Pole Creek to Coyote Flat Reservoir and eventually to the summit of the older (2-3 Ma?) calc-alkaline edifice of Soldier Mountain. For the next 14 miles, Calif. Hwy 89 is on the upper surface of the tholeiitic basalt of Pole Creek. 1.3
14.7 Clark Creek road to left (west); Cayton Valley road to right (east). View to right of the calc-alkaline edifice of Soldier Mountain. Continue straight on Calif. Hwy 89 on the upper surface of the tholeiitic basalt of Pole Creek. 6.9

21.6 Junction on right with Shasta County Road A19 from Dana, McArthur, and Fall River Mills. Continue north on Calif. Hwy 89. At 12:00 are views of Mount Shasta. 2.6

24.2 Prominent electrical transmission line. $\mathbf{1 . 5}$

25.7 USFS Road 24 on the right leads to the old logging camp of Pondosa. Continue northwest on Calif. Hwy 89.1.5

27.2 Lat $41^{\circ} 11.43^{\prime}$ N., long $121^{\circ} 44.09^{\prime}$ W. Calif. Hwy 89 crosses Pole Creek, still on the tholeiitic basalt of Pole Creek. End of road log for Lassen segment of IAVCEI field trip. Continue with Shasta segment, starting with mile 0.0 .

Bacon, C.R., Bruggman, P.E., Christiansen, R.L., Clynne, M.A., Donnelly-Nolan, J.M., and Hildreth, W., 1997, Primitive magmas at five Cascade volcanic fields; melts from hot, heterogeneous sub-arc mantle: Canadian Mineralogist, v. 35, p. 397-423.

Berge, P.A., and Stauber, D.A., 1987, Seismic refraction study of upper crustal structure in the Lassen Peak area, northern California: Journal of Geophysical Research, v. 92, p. 10571-10579.

Blakely, R.J., Christiansen, R.L., Guffanti, M., Wells, R.E., Donnelly-Nolan, J.M., Muffler, L.J.P., Clynne, M.A., and Smith, J.G, 1997, Gravity anomalies, Quaternary vents, and Quaternary faults in the southern Cascade Range, Oregon and California - Implications for arc and backarc evolution: Journal of Geophysical Research, v. 102, p. 22513-22527.

Blakeslee, M.W., and Kattenhorn, S.A., 2013, Revised earthquake hazard of the Hat Creek fault, northern California; A case example of a normal fault dissecting variable-age basaltic lavas: Geosphere, v. 9, p. 1397-1409.

Borg, L.E., 1989, Petrogenesis of Magee composite volcano, northern California: Austin, University of Texas, M.A. thesis, 128 p.

Borg, L.E, 1995, The origin and evolution of magmas from the Lassen region of the southernmost Cascades: Austin, University of Texas, Ph.D. dissertation, $228 \mathrm{p}$.

Borg, L.E., Blichert-Toft, J., and Clynne, M.A., 2002, Ancient and modern subduction zone contributions to the mantle sources of lavas from the Lassen region of California inferred from $\mathrm{Lu}-\mathrm{Hf}$ isotopic systematics: Journal of Petrology, v. 43, p. 705-723. 
Borg, L.E., Brandon, A.D., Clynne, M.A., and Walker, R.J., 2000, Re-Os isotopic systematics of primitive lavas from the Lassen region of the Cascade arc, California: Earth and Planetary Science Letters, v. 177, p. 301-317.

Borg, L.E., and Clynne, M.A., 1998, The petrogenesis of felsic calc-alkaline magmas from the southernmost Cascades, California; Origin by partial melting of basaltic lower crust: Journal of Petrology, v. 39, p. 1197-1222.

Borg, L.E., Clynne, M.A., and Bullen, T.D., 1997, The variable role of slab-derived fluids in the generation of a suite of primitive calc-alkaline lavas from the southernmost Cascade Range: Canadian Mineralogist, v. 35, p. 425-452.

Brewer, W.H., 1930, Up and down California in 1860-1864; the journal of William H. Brewer (Farquhar, F.P., ed., 4th ed.): Berkeley, University of California Press, $628 \mathrm{p}$.

Bullen, T.D., and Clynne, M.A., 1990, Trace element and isotopic constraints on magmatic evolution at Lassen Volcanic Center, California: Journal of Geophysical Research, v. 95, p. 19671-19691.

Busby, C.J., 2013, Birth of a plate boundary at ca. $12 \mathrm{Ma}$ in the ancestral Cascades arc, Walker Lane belt of California and Nevada: Geosphere, v. 9, p. 1147-1160.

Busby, C.J., Hagan, J.C., Putirka, K., Pluhar, C.J., Gans, P.B., Wagner, D.L., Rood, D., DeOreo, S.B., and Skilling, I., 2008, The ancestral Cascades arc; Cenozoic evolution of the central Sierra Nevada (California) and birth of a new plate boundary in Wright, J.E., and Shervais, J.W., eds., Ophiolites, arcs, and batholiths - A tribute to Cliff Hopson: Geological Society of America Special Paper 438, p. 331-378.

Calvert, A.T., and Christiansen, R.L., 2011, Episodic growth of Mt. Shasta, CA, documented by argon geochronology [abs.]: American Geophysical Union, Fall Meeting 2011 Abstracts, abstract no. V13C-2613, accessed May 3, 2017, at http://abstractsearch.agu.org/meetings/2011/FM/V13C2613.html.

Christiansen, R.L., Clynne, M.A, and Muffler, L.J.P., 2002, Geologic map of the Lassen Peak, Chaos Crags, and Upper Hat Creek area, California: U.S. Geological Survey Geologic Investigations Series I-2723, 1 sheet, scale 1:24,000, pamphlet $17 \mathrm{p}$.

Christiansen, R.L., and Miller, C.D., 1989, Mount Shasta and vicinity in Muffler, L.J.P., Bacon, C.R., Christiansen, R.L., Clynne, M.A., Donnelly-Nolan, J.M., Miller, C.D., Sherrod, D.R., and Smith, J.G., South Cascades arc volcanism, California and southern Oregon, Excursion 12B of Chapin, C.E., and Zidek, J., eds., Field excursions to volcanic terranes in the western United States, v. II., Cascades and Intermountain West: New Mexico Bureau of Mines and Mineral Resources Memoir 47, p. 216-225.
Clynne, M.A., 1984, Stratigraphy and major element geochemistry of the Lassen Volcanic Center, California: U.S. Geological Survey Open-File Report 84-224, 168 p.

Clynne, M.A., 1990, Stratigraphic, lithologic and major element geochemical constraints on magmatic evolution at Lassen Volcanic Center, California: Journal of Geophysical Research, v. 95, p. 19651-19669.

Clynne, M.A., 1993, Geologic studies of the Lassen Volcanic Center, Cascade Range, California: Santa Cruz, University of California, Ph.D. dissertation, 404 p.

Clynne, M.A., 1999, Complex magma mixing origin for rocks erupted in 1915, Lassen Peak, California: Journal of Petrology, v. 40 , p. $105-132$.

Clynne, M.A., and Borg, L.E., 1997, Olivine and chromian spinel in primitive calc-alkaline and tholeiitic lavas from the southernmost Cascade Range, California-A reflection of relative fertility of the source: Canadian Mineralogist, v. 35, p. 453-472.

Clynne, M.A., Champion, D.E., Trimble, D.A., Hendley, J.W., II, and Stauffer, P.H., 2000a, How old is "Cinder Cone"? - Solving a mystery in Lassen Volcanic National Park, California: U.S. Geological Survey Fact Sheet 023-00, 4 p. [Also available at http://pubs.usgs.gov/fs/2000/fs0200/.]

Clynne, M.A., Christiansen, R.L., Stauffer, P.H., Hendley, J.W., II, and Bleick, Heather, 2014, A sight "fearfully grand"-Eruptions of Lassen Peak, California, 1914 to 1917: U.S. Geological Survey Fact Sheet 2014-3119, 4 p. [Also available at http:// pubs.usgs.gov/fs/2014/3119/.]

Clynne, M.A., Christiansen, R.L., Trimble, D.A., and McGeehin, J.P., 2002, Radiocarbon dates from volcanic deposits of the Chaos Crags and Cinder Cone eruptive sequences and other deposits, Lassen Volcanic National Park and vicinity, California: U.S. Geological Survey Open-File Report 02-290, 21 p.

Clynne, M. A., Janik, C.J., and Muffler, L.J.P., 2003, Hot water in Lassen Volcanic National Park-Fumaroles, steaming ground, and boiling mudpots: U.S. Geological Survey Fact Sheet 101-02, 4 p. [Also available online at http://pubs.usgs.gov/ fs/2002/fs101-02/.]

Clynne, M.A., and Muffler, L.J.P., 2010, Geologic map of Lassen Volcanic National Park and vicinity: U.S. Geological Survey, Scientific Investigations Map 2899, 3 sheets, scale 1:50,000, pamphlet 116 p. [Also available at http://pubs.usgs.gov/ $\operatorname{sim} / 2899 /$.

Clynne, M.A., Muffler, L.J.P., and Christiansen, R.L., 2004, Late Quaternary volcanic units in the Lassen region of the Cascade Range; Recurrence intervals and intercalation with glacial deposits [abs.]: International Association of Volcanology and Chemistry of the Earth's Interior, General Assembly, Pucón, Chile, symposium 12b, abstract no. 12b_o_04, [call no. QE521.5.I58 2004]. 
Clynne, M.A., Muffler, L.J.P., Siems, D.F., Taggart, J.E., Jr., and Bruggman, P., 2008, Major and EDXRF trace element chemical analyses of volcanic rocks from Lassen Volcanic National Park and vicinity: U.S. Geological Survey OpenFile Report 2008-1091, 11 p., spreadsheet, accessed May 3, 2017, at https://pubs.usgs.gov/of/2008/1091.

Clynne, M.A., Robinson, J.E., Nathenson, M., and Muffler, L.J.P., 2012, Volcano hazards assessment for the Lassen region, northern California: U.S. Geological Survey Scientific Investigations Report 2012-5176-A, 47 p., 1 plate, scale 1:200,000. [Also available at http://pubs.usgs.gov/ $\operatorname{sir} / 2012 / 5176 / \mathrm{a} /$.

Colman, S.M., and Pierce, K.L., 1992, Varied records of early Wisconsin alpine glaciation in the western United States derived from weathering-rind thicknesses in Clark, P.U., and Lea, P.D., eds., The last interglacial-glacial transition in North America: Geological Society of America Special Paper 270, p. 269-278.

Crandell, D.R., 1972, Glaciation near Lassen Peak, northern California: U.S. Geological Survey Professional Paper 800-C, p. 179-188.

Crandell, D.R., 1989, Gigantic debris avalanche of Pleistocene age from ancestral Mount Shasta volcano, California, and debris-avalanche hazard zonation: U.S. Geological Survey Bulletin 1861, 32 p.

Crandell, D.R., Miller, C.D., Glicken, H., Christiansen, R.L., and Newhall, C.G., 1984, Catastrophic debris avalanche from ancestral Mount Shasta volcano, California: Geology, v. 12, p. 143-146.

Crandell, D.R., Mullineaux, D.R., Sigafoos, R.S., and Rubin, M., 1974, Chaos Crags eruptions and rockfall-avalanches, Lassen Volcanic National Park, California: U.S. Geological Survey Journal of Research, v. 2, p. 49-59.

Crowley, J.K., Mars, J.C., John, D.A., Muffler, L.J.P., and Clynne, M.A., 2004, Hydrothermal mineral zoning within an eroded stratocone; Remote sensing spectral analysis of Brokeoff Volcano, California in King, P.L., Ramsey, M.S., and Swayze, G.A., eds., Infrared spectroscopy in geochemistry, exploration geochemistry, and remote sensing: London, Ontario, Mineralogical Association of Canada Short Course 33, p. 215-226.

Day, A.L., and Allen, E.T., 1925, The volcanic activity and hot springs of Lassen Peak: Carnegie Institution of Washington, publication $360,190 \mathrm{p}$.

Diller, J.S., 1895, Description of the Lassen Peak sheet in Lassen Peak folio, California: U.S. Geological Survey Geologic Atlas of the United States, Folio 15, 4 p., accessed May 3, 2017, at https://pubs.er.usgs.gov/publication/gf15.
Eppler, D.B., Fink, J., and Fletcher, R., 1987, Rheologic properties and kinematics of emplacement of the Chaos Jumbles rockfall avalanche, Lassen Volcanic National Park, California: Journal of Geophysical Research, v. 92, p. 3623-3633.

Evernden, J.F., Savage, D.E., Curtis, G.H., and James, G.T., 1964, Potassium-argon dates and the Cenozoic mammalian chronology of North America: American Journal of Science, v. 262, p. 145-198.

Faulds, J.E., and Henry, C.D., 2008, Tectonic influences on the spatial and temporal evolution of the Walker Lane-An incipient transform fault along the evolving Pacific-North American plate boundary, in Spencer, J.E., and Titley, S.R., eds., Ores and orogenesis - Circum-Pacific tectonics, geologic evolution, and ore deposits: Arizona Geological Society Digest 22 , p. $437-470$.

Feeley, T.C., Clynne, M.A., Winer, G.S., and Grice, W.A., 2008a, Oxygen isotope geochemistry of the Lassen Volcanic Center, California; Resolving crustal and mantle contributions to continental arc magmatism: Journal of Petrology, v. 49, no. 5, p. 971-997.

Feeley, T.C., Wilson, L.F., and Underwood, S.J., 2008b, Distribution and compositions of magmatic inclusions in the Mount Helen dome, Lassen Volcanic National Park, California; Insights into magma chamber processes: Lithos, v. 106, p. 173-189.

Finch, R.H., 1930, Activity of a California volcano in 1786: The Volcano Letter, no. 308, p. 3.

Finch, R.H., and Anderson, C.A., 1930, The quartz basalt eruptions of Cinder Cone, Lassen Volcanic National Park, California: University of California, Department of Geological Sciences Bulletin, v. 19, p. 245-273.

Germa, A., Conner, C., Connor, L., Malservisi, R., Tavarez, S., Charbonnier, S., Clynne, M.A., Perry, C., Quidelleur, X., and Ricci, J., 2015, New geochronological constraints of the Lassen segment's regional volcanism: American Geophysical Union, Fall Meeting 2011 Abstracts, abstract no. V31A, accessed May 17, 2017, at http://abstractsearch.agu.org/meetings/2015/FM/ V31A-3008.html.

Gill, J.B., 1981, Orogenic andesites and plate tectonics: New York, Springer-Verlag, $390 \mathrm{p}$.

Grose, T.L.T., Saucedo, G.J., and Wagner, D.L., 2013, Preliminary geologic map of the Susanville 30' x 60' quadrangle, California: California Division of Mines and Geology, available at ftp://ftp.consrv.ca.gov/pub/dmg/rgmp/Prelim_geo_pdf/ Susanville_100k_v2.0_Map.pdf; accompanying pamphlet available at ftp://ftp.consrv.ca.gov/pub/dmg/rgmp/Prelim_geo_ pdf/Susanville_100k_v2.0_Pamphlet.pdf. 
Guffanti, M., Clynne, M.A., and Muffler, L.J.P., 1996, Thermal and mass implications of magmatic evolution in the Lassen volcanic region, California, and minimum constraints on basalt influx to the lower crust: Journal of Geophysical Research, v. 101, p. 3003-3013.

Guffanti, M., Clynne, M.A., Smith, J.G., Muffler, L.J.P., and Bullen, T.D., 1990, Late Cenozoic volcanism, subduction and extension in the Lassen region of California, Southern Cascade Range: Journal of Geophysical Research, v. 95, p. 19453-19464.

Guffanti, M., and Weaver, C.S., 1988, Distribution of late Cenozoic volcanic vents in the Cascade Range, volcanic arc segmentation and regional tectonic considerations: Journal of Geophysical Research, v. 93, p. 6513-6529.

Harkness, H.W., 1875, A recent volcano in Plumas County: Proceedings of the California Academy of Sciences, v. 5, p. $408-412$.

Hart, G.L., Johnson, C.M., Shirey, S.B., and Clynne, M.A., 2002, Osmium isotope constraints on lower crustal recycling and pluton preservation at Lassen Volcanic Center, CA: Earth and Planetary Science Letters, v. 199, p. 269-285.

Heath, J.P., 1959, Dating Chaos Jumbles, an avalanche deposit in Lassen Volcanic National Park: American Journal of Science, v. 257, p. 537-538.

Helley, E.J., and Harwood, D.S., 1985, Geologic map of the late Cenozoic deposits of the Sacramento Valley and northern Sierra Foothills, California: U.S. Geological Survey Miscellaneous Field Studies Map MF 1790, 5 sheets, scale 1:62,500, pamphlet $24 \mathrm{p}$.

Helley, E.J., Harwood, D.S., Barker, J.A., and Griffin, E.A., 1981, Geologic map of the Battle Creek Fault Zone and adjacent parts of the northern Sacramento Valley, California: U.S. Geological Survey Miscellaneous Field Studies Map MF-1298, scale 1:62,500.

Ingebritsen, S.E., Bergfeld, D., Clor, L.E., and Evans, W.C., 2016, The Lassen hydrothermal system: American Mineralogist, v. 101, p. 343-354.

Ingebritsen, S.E., and Sorey, M.L., 1985, A quantitative analysis of the Lassen hydrothermal system, north central California: Water Resources Research, v. 21, p. 853-868.

Janik, C.J., and McLaren, M.K., 2010, Seismicity and fluid geochemistry at Lassen Volcanic National Park, California; Evidence for two circulation cells in the hydrothermal system: Journal of Volcanology and Geothermal Research, v. 189 , p. $257-277$.
John, D.A., Breit, G.N., Lee, R.G., Dilles, J.H., Muffler, L.J.P., and Clynne, M.A., 2006, Fossil magmatic-hydrothermal systems in Pleistocene Brokeoff Volcano, Lassen Volcanic National Park [abs.]: American Geophysical Union, Fall Meeting 2006 Abstracts, abstract no. V53A-1745, accessed May 3, 2017, at http://abstractsearch.agu.org/ meetings/2006/FM/V53A.html.

John, D.A., Rytuba, J.J., Breit, G.N., Clynne, M.A., and Muffler, L.J.P., 2005, Hydrothermal alteration in Maidu Volcano; A shallow fossil acid-sulfate magmatichydrothermal system in the Lassen Peak area, California in Rhoden, H.N., Stininger, R.C., and Vikre, P.G., eds., Window to the World: Geological Society of Nevada Symposium 2005, p. 295-313.

Kane, P., 1982, Pleistocene glaciation, Lassen Volcanic National Park: California Geology, v. 35, p. 95-105.

Kattenhorn, S.A., Krantz, B., Walker, E.L., and Blakeslee, M.W., 2016, Evolution of the Hat Creek Fault system, northern California, in Krantz, B., Ormand, C., and Freeman, B., eds., D structural interpretation-Earth, mind, and machine: American Association of Petroleum Geologists Memoir 111, p. 121-154.

KellerLynn, K., 2014, Lassen Volcanic National Park; geologic resources inventory report: National Park Service, Natural resource report NPS/NRSS/GRD/NRR_-2014/755, 66 p., 2 sheets, accessed May 19, 2017, at https://www. nature.nps.gov/geology/inventory/publications/reports/ lavo_gri_rpt_view.pdf

Klemetti, E.W., and Clynne, M.A., 2014, Localized rejuvenation of a crystal mush recorded in zircon temporal and compositional variation at the Lassen Volcanic Center, northern California: PLoS ONE v. 9, no. 12, doi:10.1371/ journal.pone.0113157, $22 \mathrm{p}$.

LaForge, R.C., and Hawkins, F.F., 1986, Seismotectonic study of northernmost California for Shasta, Keswick, Spring Creek Debris, Trinity, Lewiston, and Whiskeytown Dams: U.S. Bureau of Reclamation Seismotectonic Report No. 86-1, $132 \mathrm{p}$.

Langenheim, V.E., Jachens, R.C., Muffler, L.J.P., and Clynne, M.A., 2016, Implications for the structure of the Hat Creek Fault and transfer of right-lateral shear from the Walker Lane north of Lassen Peak, northern California, from gravity and magnetic data: Geosphere, v. 12, no. 3, p. 790-808, doi:10.1130/GES01253.1.

Lanphere, M.A, Champion, D.E., Clynne, M.A., Lowenstern, J.B., Sarna-Wojcicki, A.M., and Wooden, J.L., 2004, Age of the Rockland tephra, western U.S.A.: Quaternary Research, v. 62, p. 94-104. 
Lanphere, M.A, Champion, D.E., Clynne, M.A., and Muffler, L.J.P., 1999, Revised age of the Rockland tephra, northern California-Implications for climate and stratigraphic reconstructions in the western United States: Geology, v. 27, p. $135-138$.

Lydon, P.A., 1968, Geology and lahars of the Tuscan Formation, northern California in Coats, R.R., Hay, R.L., and Anderson, C.A., eds., Studies in volcanology-A memoir in honor of Howel Williams: Geological Society of America Memoir 116, p. 441-475.

Macdonald, G.A., 1963, Geologic map of the Manzanita Lake quadrangle, California: U.S. Geological Survey Geologic Quadrangle Map GQ-248, scale 1:62,500.

Macdonald, G.A., 1964, Geologic map of the Prospect Peak quadrangle, California: U.S. Geological Survey Geologic Quadrangle Map GQ-345, scale 1:62,500.

Macdonald, G.A., 1965, Geologic map of the Harvey Mountain quadrangle, California: U.S. Geological Survey Geologic Quadrangle Map GQ-443, scale 1:62,500.

Meyer, C.E., Sarna-Wojcicki, A.M., Hillhouse, J.W., Woodward, M.J., Slate, J.L., and Sorg, D.H, 1991, Fission-track age (400,000 yr) of the Rockland tephra, based on inclusion of zircon grains lacking fossil fission tracks: Quaternary Research, v. 35, p. 367-382.

Meyer, C.E., Woodward, M.J., Sarna-Wojcicki, A.M., and Naeser, C.W., 1980, Zircon fission-track age of 0.45 million years on ash in the type section of the Merced Formation, west-central California: U.S. Geological Survey Open-File Report 8193, 16 p.

Muffler, L.J.P., Champion, D.E., Calvert, A.T., and Clynne, M.A., 2012, Paleomagnetic, geochronologic, and petrologic data discriminate tholeiitic basalts of the northern Hat Creek Graben, northeastern California [abs]: American Geophysical Union, 2012 Fall Meeting, San Francisco, Calif., Dec. 3-7, Abstract V33B-2868.

Muffler, L.J.P., and Clynne, M.A., 2015, Geologic field-trip guide to Lassen Volcanic National Park and vicinity: U.S. Geological Survey Scientific Investigations Report 2015$5067,67 \mathrm{p}$.

Muffler, L.J.P., Clynne, M.A., Calvert, A.T., and Champion, D.E. 2011, Diverse, discrete, mantle-derived batches of basalt erupted along a short normal fault zone; the Poison Lake chain, southernmost Cascades: Geological Society of America Bulletin, v. 123, p. 2177-2200.

Muffler, L.J.P., Clynne, M.A., and Champion, D.E., 1994, Late Quaternary normal faulting of Hat Creek Basalt, northern California: Geological Society of America Bulletin, v. 106, p. 195-200.
Muffler, L.J.P., Jordan, R., and Cook, A.L., 1983, Maps showing thermal features and topography of Devils Kitchen and Bumpass Hell, Lassen Volcanic National Park, California: U.S. Geological Survey Miscellaneous Field Studies Map MF-1484, 2 sheets, scale $1: 2,000$.

Muffler, L.J.P., Nehring, N.L., Truesdell, A.H., Janik, C.J., Clynne, M.A., and Thompson, J.M., 1982, The Lassen geothermal system: Proceedings of Pacific Geothermal Conference 1982, part 2, p. 349-356.

Muffler, L.J.P., Robinson, J.E., Felger, T.J., Dutton, D.R., and Clynne, M.A., 2010, Database for the geologic map of Lassen Volcanic National Park and vicinity, California in Clynne, M.A., and Muffler, L.J.P., Geologic map of Lassen Volcanic National Park and vicinity: U.S. Geological Survey Scientific Investigations Map 2899, scale 1:50,000 [CD-ROM].

Nathenson, M., Clynne, M.A, and Muffler, L.J.P., 2012, Eruption probabilities for the Lassen Volcanic Center and regional volcanism, northern California, and probabilities for large explosive eruptions in the Cascade Range: U.S. Geological Survey Scientific Investigations Report 2012-5176-B, 23 p., accessed May 3, 2017, at https://pubs.er.usgs.gov/publication/ $\operatorname{sir} 20125176 \mathrm{~B}$.

Robinson, J.E., and Clynne, M.A., 2012, Lahar hazard zones for eruption-generated lahars in the Lassen Volcanic Center, California: U.S. Geological Survey Scientific Investigations Report 2012-5176-C, 13 p., accessed May 3, 2017, at https://pubs.er.usgs.gov/publication/sir20125176C.

Rood, D., Amidon, W, McKeon, R, Baldwin, J., Gray, B, Page, W., and Farley, K., 2015, Paleoseismic assessment of the Hat Creek fault using cosmogenic He-3 surface exposure dating in basalt, northeastern California: A proof of concept study [abs.]: American Geophysical Union, Fall Meeting 2015 Abstracts, abstract no. T42A-01, accessed May 8, 2017, at https://agu.confex.com/agu/ fm15/meetingapp.cgi/Paper/69995.

Sarna-Wojcicki, A.M., Meyer, C.E., Bowman, H.R., Hall, N.T., Russell, P.C., Woodward, M.J., and Slate, J.L., 1985, Correlation of the Rockland Ash Bed, a 400,000-year-old stratigraphic marker in northern California and western Nevada, and implications for middle Pleistocene paleogeography of central California: Quaternary Geology, v. 23, p. 236-257.

Scruggs, M.A., Putirka, K.D., and Clynne, M.A., 2014, Enclave formation and magma mixing at Chaos Crags, California [abs]: Goldschmidt 2014 conference abstracts, abstract no. 2241, accessed May 8, 2017, at https://goldschmidt.info/2014/uploads/ abstracts/finalPDFs/A-Z.pdf.

Sheppard, P.R., Ort, M.H., Anderson, K.C., Clynne, M.A., and May, E.M., 2009, Multiple dendrochronological responses to the eruption of Cinder Cone, Lassen Volcanic National Park, California: Dendrochronologia, v. 27, p. 213-221. 
Sherrod, D.R., and Smith, J.G., 1990, Quaternary extrusion rates of the Cascade Range, northwestern United States and southern British Columbia: Journal of Geophysical Research, v. 95, p. 19465-19474.

Sisson, T.W., and Layne, G.D., 1993, $\mathrm{H}_{2} \mathrm{O}$ in basaltic and basaltic andesite glass inclusions from four subductionrelated volcanoes: Earth and Planetary Science Letters, v. 117 , p. $619-635$.

Sorey, M.L., and Ingebritsen, S.E., 1995, Heat and mass flow from thermal areas in and adjacent to Lassen Volcanic National Park, California, USA: International Geothermal Association, Proceedings of the World Geothermal Congress, Florence, Italy, 1995, v. 2, p. 751-755.

Strong, D.H., 1989, These happy grounds; a history of the Lassen Region: Red Bluff, Calif., Loomis Museum Association, fourth printing, $99 \mathrm{p}$.

Sun, A.S., and McDonough, W.F., 1989, Chemical and isotopic systematics of oceanic basalts; implications for mantle composition and processes in Saunders, A.D., and Norry, M.J., eds. Magmatism in the ocean basins: Geological Society of London Special Publications v. 42, p. 313-345.

Tepley, F.J., III, Davidson, J.P., and Clynne, M.A., 1999, Magmatic interactions as recorded in plagioclase phenocrysts of Chaos Crags, Lassen Volcanic Center, California: Journal of Petrology, v. 40, p. 787-806.

Turrin, B.D., Christiansen, R.L., Clynne, M.A., Champion, D.E, Gerstel, W.J., Muffler, L.J.P., and Trimble, D.A., 1998, Age of Lassen Peak, California, and implications for the ages of late Pleistocene glaciations in the southern Cascade Range: Geological Society of America Bulletin, v. 110, p. 931-945.
Turrin, B.D., Muffler, L.J.P., Clynne, M.A., and Champion, D.E., 2007 , Robust $24 \pm 6 \mathrm{ka}{ }^{40} \mathrm{Ar} /{ }^{39} \mathrm{Ar}$ age of a lowpotassium tholeiitic basalt in the Lassen region of NE California: Quaternary Research, v. 68, p. 96-110.

Unruh, J.R., 1995, Late Cenozoic tectonics of the Greater Walker Lane Belt and implications for active deformation in the Lake Almanor Region, northeastern California, in Page, W.D., ed., Quaternary geology along the boundary between the Modoc Plateau, southern Cascade Mountains, and northern Sierra Nevada: Friends of the Pleistocene, 1995 Pacific Cell Field Trip, appendix B, $11 \mathrm{p}$.

Unruh, J.R., Humphrey, J., and Barron, A., 2003, Transtensional model for the Sierra Nevada frontal fault system, eastern California: Geology, v. 31, p. 327-330, doi:10.1130/00917613(2003)031<0327:TMTFSN>2.0.CO:2.

Waldhauser, F., and Schaff, D.P., 2008, Large-scale relocation of two decades of Northern California seismicity using cross-correlation and double-difference methods, Journal of Geophysical Research, v. 113, B08311, doi:10.1029/ 2007JB005479.

Walker, E.L., 2008, Evolution of the Hat Creek fault system, northern California: Moscow, University of Idaho, M.S. thesis, $112 \mathrm{p}$.

Walker, E.L., and Kattenhorn, S.A., 2008, Slip history and evolution of the Hat Creek Fault, Northern California [abs]: American Geophysical Union Fall Meeting 2008 Abstracts, abstract no. T21B-1976, accessed May 8, 2017, at http://abstractsearch.agu. org/meetings/2008/FM/T21B-1976.html.

Williams, H., 1932, Geology of the Lassen Volcanic National Park, California: Berkeley, University of California Department of Geological Sciences Bulletin, v. 21, p. 195-385.

Wilson, T.A., 1961, The geology near Mineral, California: Berkeley, University of California, M.S. thesis, $92 \mathrm{p}$. 
